\title{
(1)
}

UNIVERSIDAD PERUANA DE CIENCIAS APLICADAS

FACULTAD DE NEGOCIOS

PROGRAMA AADÉMICO DE NEGOCIOS INTERNACIONALES

\section{FACTORES CRÍTICOS DE ÉXITO PARA LA EXPORTACIÓN DE ROPA DE BAÑO Y BIKINIS A FRANCIA EN EL PERÍODO 2013 - 2016}

\author{
TESIS \\ Para optar el titulo profesional de Licenciado en Negocios Internacionales
}

AUTORES

Agreda Garay, Ingrid Yazmín (0000-0002-1334-4529)

Vidal Gerstein, Miluska Shimara (0000-0003-1586-8665)

Asesora:

Pérez Aponte, María Cecilia (0000-0002-9988-7312)

Lima, Agosto del 2018 
La presente investigación está dedicada a nuestros padres y profesores con mucho cariño, a pesar de diversos obstáculos que hemos pasado, nos siguieron alentando y apoyando para retroalimentarnos y seguir adelante con mayor fuerza. 


\section{AGRADECIMIENTOS}

\section{A los representantes de las instituciones públicas,}

Por la atención en su centro de labores, brindándonos un poco de su tiempo para compartir su conocimiento, experiencias y opiniones que enriquecen la presente investigación.

\section{A los empresas exportadoras,}

Por la apertura y disposición a realizar amenas charlas, que ayudaron a esclarecer puntos estratégicos del comercio internacional.

\section{A nuestra asesora,}

Por encaminarnos en el sendero correcto del desarrollo de una tesis, con dedicación y ahínco, brindándonos sus conocimientos que sirvieron para corregir errores y demoras de este largo proceso de elaboración de la investigación.

\section{A los centros laborales,}

A pesar de largas jornadas laborales a cumplir, nos brindaron facilidades para la culminación de la presente investigación.

\section{A nuestros padres y familiares}

Por su comprensión y apoyo en el sacrificio emprendido para la culminación del trabajo de investigación. 


\section{RESUMEN}

La presente investigación tiene por finalidad determinar los factores críticos de éxito que consolidan el posicionamiento comercial de la exportación de ropas de baño y bikinis desde Lima-Perú a Francia.

Para tal fin, en el primer capítulo, se revisan los documentos e investigaciones que logran presentar la demanda y oferta de las prendas a nivel nacional y mundial, así como, también se investiga y analiza al destino potencial francés, con lo cual, se ha podido verificar y analizar las importaciones de ropas de baño y bikinis que realiza este país. En el segundo capítulo, se presenta la metodología de la investigación, donde se ha determinado emplear la investigación cualitativa; la cual, busca mostrar la realidad de uno o varios sectores comerciales que se interrelacionan en un determinado contexto, así también, se da a conocer los objetivos, hipótesis, problemas, justificación y los grupos de actores que se entrevistarán; teniendo como base el Plan Estratégico Nacional de Exportaciones (PENX 2025). En el tercer capítulo, se expone la información detallada de acuerdo a la organización de cada segmento y dimensión; obteniendo resultados de un proceso cualitativo en donde podemos identificar diferentes estrategias relacionadas al tema de investigación, y mejorar e incrementar nuestra participación de mercado en el país de Francia. En el cuarto capítulo, se dan a conocer los hallazgos, las barreras y brechas de la información, de las cuales ha sido sujeta la investigación. En el quinto y último capítulo, se informan las conclusiones y recomendaciones de la presente investigación.

Palabras clave: Textil, ropa de baño, bikini, Francia, exportación. 


\section{$\underline{\text { ABSTRACT }}$}

The purpose of this investigation is to determine the critical success factors that consolidate the commercial positioning of the exportation of swimsuits and bikinis from Lima-Peru to France.

To this end, the first chapter reviews the documents and research that manages to present the demand and supply of garments at national and global level, as well as investigate and analyze the potential French destination, with which, the importation of swimsuits and bikinis made in this country, could be verified and analyzed. In the second chapter it's presented the methodology of the investigation qualitative; which seeks to show the reality of one or several commercial sectors that interrelate in a specific context. Also, we present the objectives, hypotheses, problems, justification and the groups of actors that will be interviewed are announced; having as base the National Strategic Plan of Exports (PENX 2025). In the third chapter, it's exposed the detailed information according to the organization of each segment and dimension; obtaining results of a qualitative process where we can identify different strategies related to the research topic, and improve and increase our market share in the country of France. In the fourth chapter, we presents the findings, barriers and information gaps to which the research has been submitted are presented. In the fifth and last chapter, the conclusions and recommendations of the present investigation are reported.

Key Word: Textil, swimsuit, bikini, France, export. 


\section{INDICE}

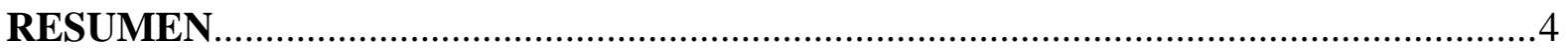

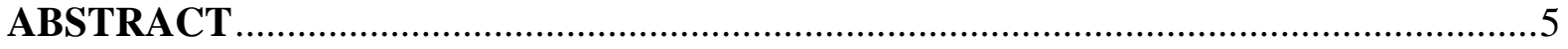

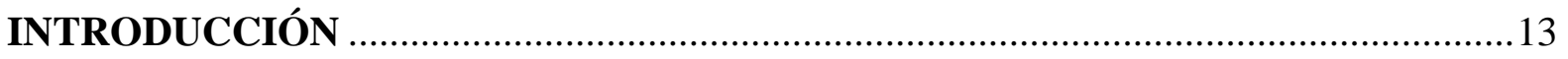

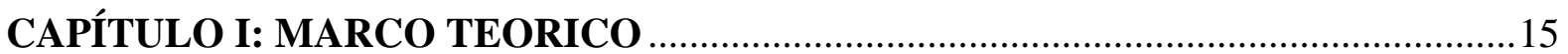

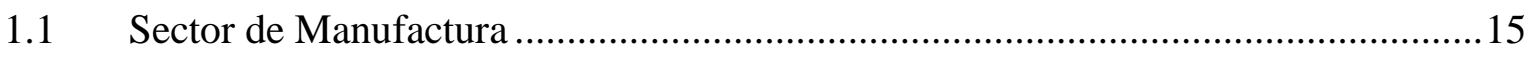

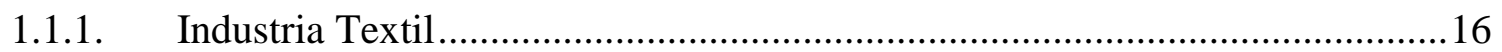

1.1.2. Panorama Económico Global del Comercio Internacional...............................24

1.1.3. Panorama económico Francés.......................................................................... 32

1.1.4. Panorama económico del Perú.........................................................................

1.1.5. Industria Textil Prendas de baño Perú .................................................................49

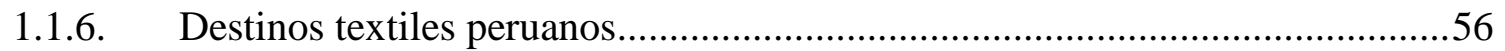

1.1.7. Disposiciones del comercio Internacional ..................................................60

1.1.8. El Perú y la Organización Mundial del Comercio - OMC ..............................61

1.1.9. Compromisos en el Marco de Acuerdo Multipartes con la UE ........................66

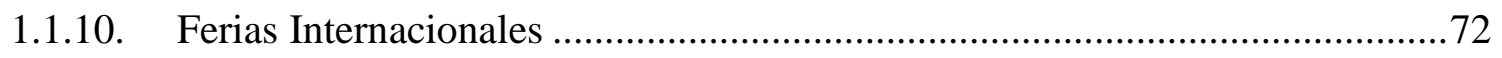

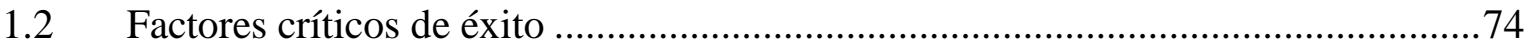

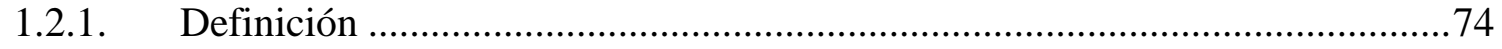

1.2.2. Factores Críticos de Éxito en la exportación ....................................................76

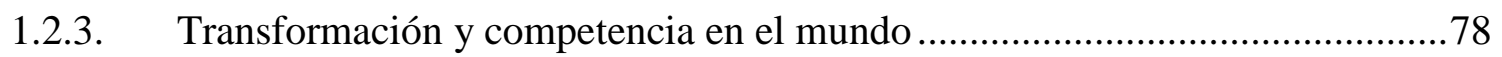

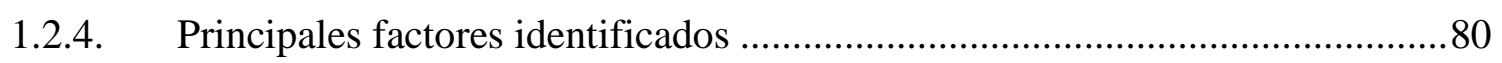

CAPÍTULO II: METODOLOGÍA DE LA INVESTIGACIÓN ......................................82

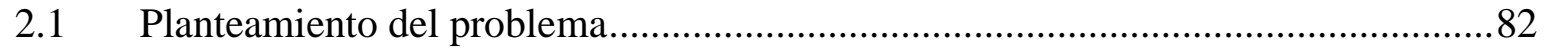

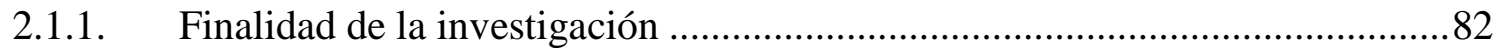

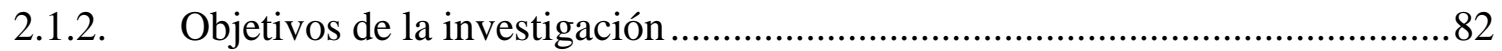

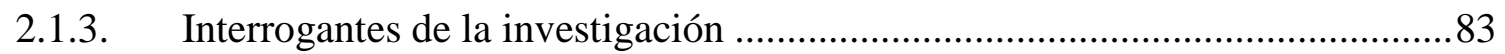

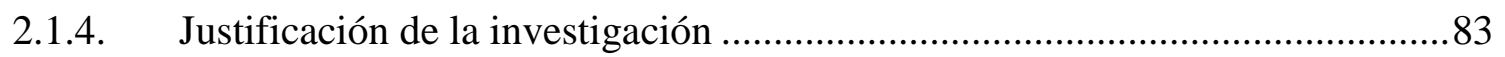

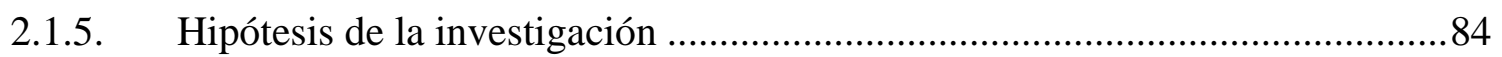

2.2 Metodología de la investigación ................................................................... 85

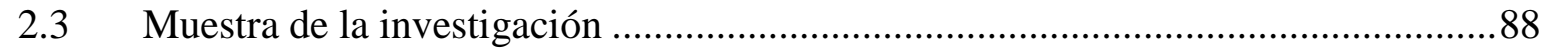

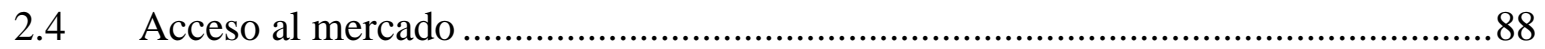


2.5 Diseño de la investigación .88

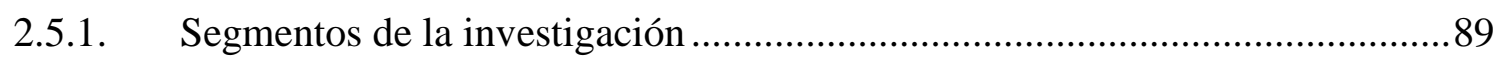

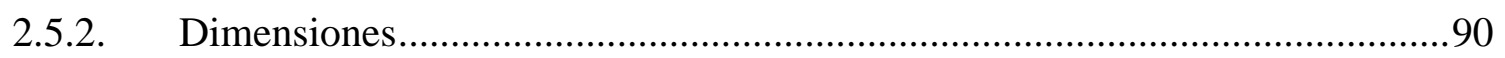

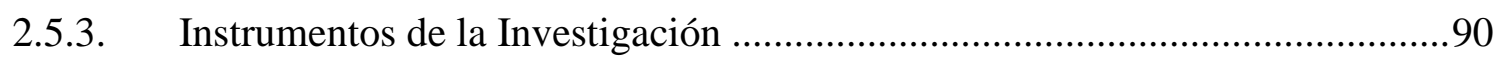

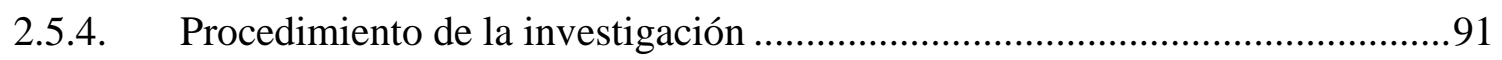

CAPÍTULO III: ANÁLISIS DE INFORMACIÓN Y RESULTADOS ...........................93

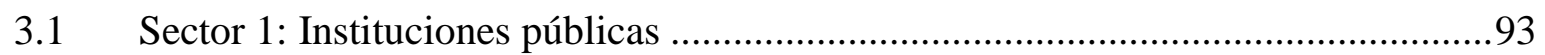

3.1.1. Dimensión 1: Capacidad productiva y ventajas competitivas de la oferta exportable de ropas de baño y bikinis para damas.

3.1.2. Dimensión 2: Barreras arancelarias y proceso logístico de la oferta exportable de ropas de baño y bikinis para damas.

3.1.3. Dimensión 3: Comercio y demanda internacional de la oferta exportable de

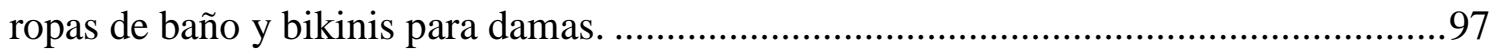

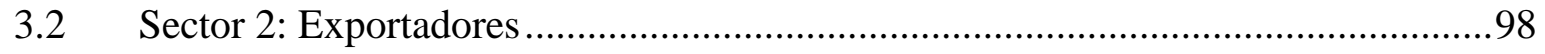

3.2.1. Dimensión 1: Capacidad productiva y ventajas competitivas de la oferta exportable de ropas de baño y bikinis para damas..... .98

3.2.2. Dimensión 2: Barreras arancelarias y proceso logístico de la oferta exportable de ropas de baño y bikinis para damas.

3.2.3. Dimensión 3 : Comercio y demanda internacional de la oferta exportable de

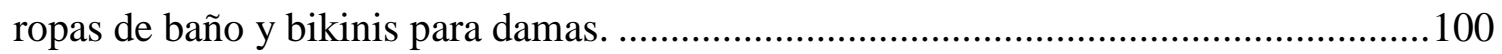

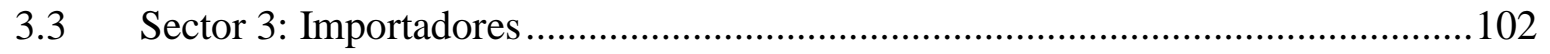

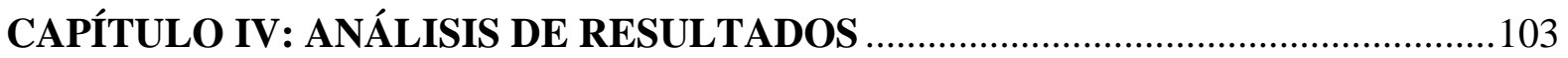

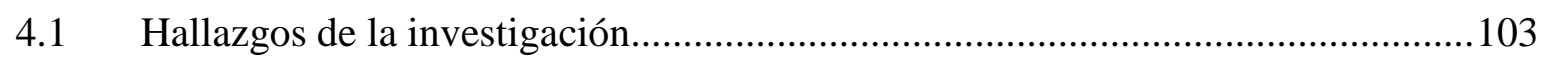

4.1.1. Dimensión 1: Capacidad productiva y ventajas competitivas de la oferta exportable de ropas de baño y bikinis para damas........................................................ 103

4.1.2. Dimensión 2: Barreras arancelarias y proceso logístico de la oferta exportable

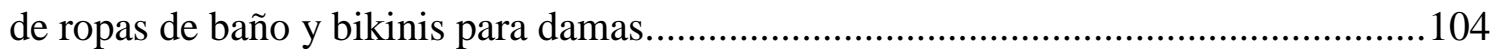

4.1.3. Dimensión 3: Comercio y demanda internacional de la oferta exportable de

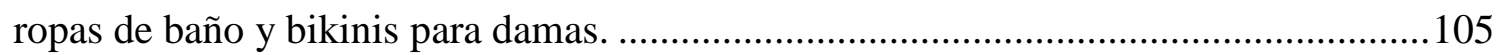

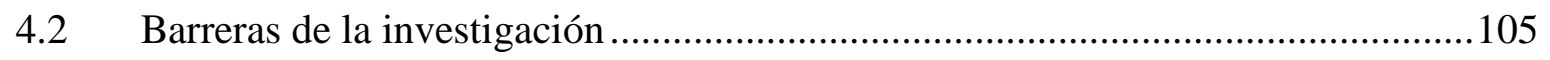

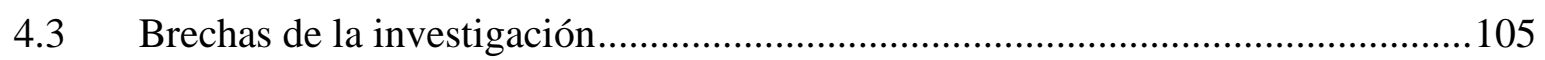

CAPÍTULO V: CONCLUSIONES Y RECOMENDACIONES ...................................107

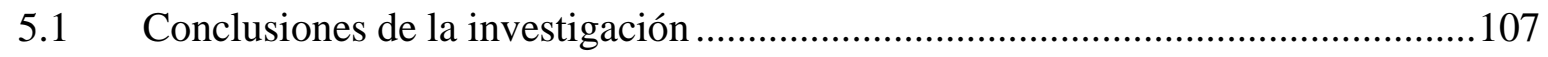




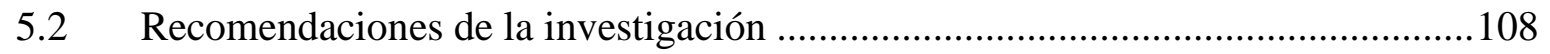

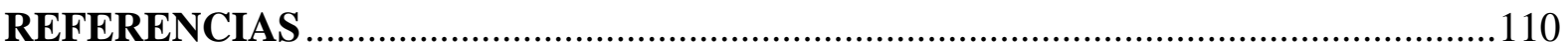

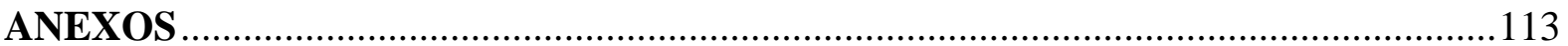




\section{INDICE DE TABLAS}

TABla 1: Índices Macroeconómicos de Francia. Adaptado Datos Macro Países...................34

TABLA 2. Producto Bruto Interno por tipo de Gasto 2013 al 2017 expresado en millones de soles. Fuente: Informe Técnico INEI (2017) ............................................................46

TABLA 3. Partidas principales del sector textil, exportadas a Francia del 2014 al 2016. Adaptado

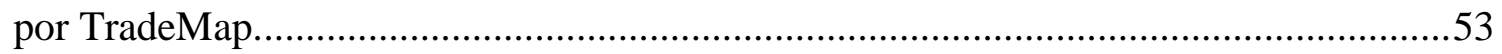

Tabla 4. Exportaciones peruanas hacia Francia y hacia el mundo del 2012 - 2016. Fuente:

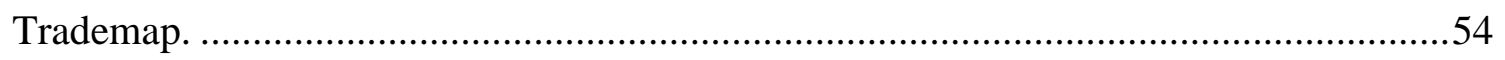

Tabla 5. Exportaciones Peruanas hacia Francia del 2013 - 2016. Fuente: Trademap. ...........55

Tabla 6. Exportadores peruanos hacia Francia del 2013 - 2016. Fuente: Trademap..............55

Tabla 7. Importadores Franceses que realizaron operaciones comerciales con exportadores

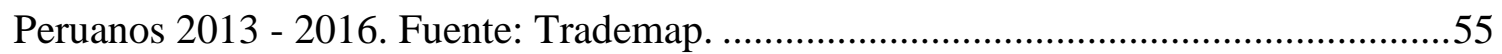




\section{INDICE DE FIGURAS}

Figura 1. Mapa de los Estados y territorios libres y esclavos en el año 1858.

Figura 2. Método húmedo: método que por cambio de solvente el polímero se coagula y solidifica en una solución química. (Ej. Rayón viscosa, rayón cupro, algunas acrílicas, modacrílicas y elastano). Adaptado por Introducción a la tecnología textil por Pesok, M. J. C. (2012). Figuras reproducidas con la .... autorización de la "British Man-Made Fibers Federation").

Figura 3. Método seco: es aquel que por evaporación del solvente en aire caliente el polímero en solución se solidifica (Ej. rayon acetato, triacetato, clorofibras, algunas acrílicas, modacrílicas y elastano). Adaptado por Introducción a la tecnología textil por Pesok, M. J. C. (2012). Figuras reproducidas con la autorización de la "British Man-Made Fibers Federation").

Figura 4. Método por fusión y solidificación: método que por enfriamiento el polímero fundido se solidifica (Ej. poliamidas, poliéster, polietileno, polipropileno). Adaptado por Introducción a la tecnología textil por Pesok, M. J. C. (2012). Figuras reproducidas con la autorización de la "British Man-Made Fibers deration").

Figura 5. Exportaciones del Perú con EEUU, China y UE. Fuente. Elaboración propia con datos extraídos de Mincetur, BCRP, CCEX- CCL, Instituto de Economía y Desarrollo Empresarial de la Cámara de Comercio de Lima. Revista CCL Nª 819. .27

Figura 6: Principales Importadores Mundiales de ropas de baño y bikinis para damas del 2013 - 2017. Fuente: Elaboración propia adaptado de Trade Map. .28

Figura 7: Principales exportadores mundiales de ropas de baño y bikinis para damas del 2012 - 2016. Fuente. Elaboración propia adaptado de Trade Map.

Figura 8: Porcentaje de Importaciones de Bienes y Servicios respecto al PBI

Francia

. Elaboración propia con datos tomados de Indicadores de Desarrollo Mundial del Banco Mundial.

Figura 9. Principales proveedores de Francia Elaboración propia. Fuente: TradeMap .36

Figura 10. Distribución de la Producción de Francia del 2013. Adaptado por Estudio de mercado de Moda en Francia de ropas de Baño PROCOLOMBIA (2013) Fuente:Maison du prêt à porter. 37 
Figura 11. Canales de Distribución de Francia en el 2013. Adaptado por Estudio de mercado de Moda en Francia de ropas de Baño PROCOLOMBIA (2013) Fuente: Cálculos Proexport.

Figura 12. División del mercado mundial. Adaptado por Estudio de mercado de Moda en Francia de ropas de Baño PROCOLOMBIA (2013) Fuente: Creations Lingerie. .39

Figura 13. Principales consumidores de Trajes de Baño fuera de USA expresado en millones de euros. Adaptado por Estudio de mercado de Moda en Francia de ropas de Baño PROCOLOMBIA (2013). Fuente: Estudio de mercado de Mode City realizado por NPD Group.

Figura 14. Población de género femenino en Francia. Elaboración propia con datos tomados de Indicadores de Desarrollo Mundial del Banco Mundial.

Figura 15. Ventas por género y Niños. Adaptado por Estudio de mercado de Moda en Francia de ropas de Baño PROCOLOMBIA (2013). Fuente: Estudio de mercado de Mode City realizado por NPD Group.

Figura 16. Ventas por tipo de traje de baño. Adaptado por Estudio de mercado de Moda en Francia de ropas de Baño PROCOLOMBIA (2013). Fuente: Estudio de mercado de Mode City realizado por NPD Group.

Figura 17. Finalidad de compra de traje de baño. Adaptado por Estudio de mercado de Moda en Francia de ropas de Baño PROCOLOMBIA (2013). Fuente: Estudio de mercado de Mode City realizado por NPD Group.

Figura 18. Diseños utilizados. Adaptado por Estudio de mercado de Moda en Francia de ropas de Baño PROCOLOMBIA (2013). Fuente: http://www.creations-lingerie.com/ .

Figura 19. Principales proveedores de Francia de bañadores de fibra sintética para damas 2013 - 2017 Fuente: TradeMap.

Figura 20. Mercados importadores para el producto bañadores de fibra sintética exportado por Francia del 2013 al 2017. Fuente: TradeMap.

Figura 21. Principales países destino de exportaciones de Perú. Fuente: (Informe Técnico INEI 2018)

Figura 22. Porcentaje de Exportaciones de Bienes y Servicios respecto al PBI Perú. Elaboración propia con datos tomados de Indicadores de Desarrollo Mundial del Banco Mundial.

Figura 23. Exportaciones peruanas a Francia de Vestimenta 2016. Adaptado por SUNAT 2017. .48 
Figura 24. Exportaciones peruanas a Francia de Vestimenta 2012- 2016. Adaptado por SUNAT 2017

Figura 25. Flujo de la cadena productiva del sector textil. Adaptado por Reporte sectorial SNIIEES 2016. Fuente Reportes Financieros CETRUM 2010.

Figura 26. Exportaciones peruanas a Francia del sector textil del 2012 al 2016. Adaptado por SUNAT cifras en millones de dólares - PROMPERU (2017). .50

Figura 27. Exportaciones peruanas a Francia del sector textil del 2012 al 2016. Adaptado por SUNAT cifras en millones de dólares - PROMPERU (2017). .50

Figura 28. Mapa de mercados importadores de un producto exportado por Perú en el 2016 Partida Arancelaria: 611241. Fuente: Trademap (2018).

Figura 29. Principales Importadores y Exportadores para el producto bañadores de punto, de fibras sintéticas para mujeres y niñas exportado por Perú. Fuente: Siicex (2018) .57

Figura 30. Principales Importadores y Exportadores para el producto bañadores de punto, de fibras sintéticas para mujeres y niñas exportado por Perú. Fuente: Siicex (2018) .57

Figura 31. Exportaciones Peruanas del 2014 Partida $N^{\circ} 6112410000$ Trajes de baño de fibra sintética para damas y niñas. Fuente: Elaboración propia con información Extraída de Aduanet. .58

Figura 32. Exportaciones Peruanas del 2015 Partida N 6112410000 Trajes de baño de fibra sintética para damas y niñas. Fuente: Elaboración propia con información Extraída de Aduanet. .58

Figura 33. Exportaciones Peruanas del 2016 Partida N ${ }^{a} 6112410000$ Trajes de baño de fibra sintética para damas y niñas. Fuente: Elaboración propia con información Extraída de Aduanet.

Figura 34. Exportaciones Peruanas del 2017 Partida N ${ }^{a} 6112410000$ Trajes de baño de fibra sintética para damas y niñas. Fuente: Elaboración propia con información Extraída de Aduanet. .59 


\section{INTRODUCCIÓN}

Con el desarrollo de la gran industria y la llegada del nuevo milenio, las necesidades del ser humano han variado con el paso de los años. Tal es así, que ahora para realizar actividades de esparcimiento en el verano, las personas necesita múltiples productos y servicios que lo satisfagan a plenitud en los momentos de relax. Estos momentos de relax, como refrescarse en las aguas del mar o piscinas, en lugares paradisiacos, son aún mejores, cuando se usa una prenda que lo haga sentir cómodo. Esta actividad tan usual en todo el mundo, ha hecho que se desarrolle un gigantesco mercado en este sector textil, y así, lo muestran las estadísticas globales de traje de baño que en el 2011 ascendió a \$ 16 bn., en el 2015 a \$ 19 bn. y, para el 2018 se pronostica llegará a \$20.5 bn. (Euromonitor International, Enero 2018).

La UE es el segundo exportador mundial de textiles y prendas de vestir con una facturación de 162000 millones de euros, 174100 empresas y 166 millones de trabajadores. Cada vez más mercados europeos apuestan por la inversión industrial textil, no sólo exportando, sino, también importando productos de alta calidad de distintas partes del mundo.

Las grandes transnacionales textiles, realizan aperturas de tiendas fast-fashion en todos los países donde el comercio textil tiene auge. Existen capitales de la moda que gracias a su industria han logrado un amplio desarrollo como son París, Milán, Londres y Nueva York, se piensa en una quinta capital en la cual compiten México, Tokio, Berlín y Madrid.

También, podemos resaltar que el mayor importador de prendas de baño es Estados Unidos, seguido de China, y países europeos como Alemania, Francia, Reino Unido, España e Italia, 
países que están a la vanguardia de la moda y tecnología textil. Estos países destacan por el amplio desarrollo comercial en el rubro textil, adquiriendo prendas para luego comercializarlos a nivel mundial.

El Perú, es reconocido por brindar productos de calidad y tiene un pujante sector textil con innumerables empresas comprometidas en ofrecer el mejor producto con valor agregado y satisfacer las necesidades del consumidor extranjero.

Siendo la Unión Europea un gigantesco potencial mercado para este rubro textil y teniendo a Francia como uno de los países de la moda y tendencias alcanzando el segundo lugar como consumidor de trajes de baño después de Estados Unidos según un Estudio de Mercado Mode City realizado por NPD Group en el 2013, dentro de todo ese contexto comercial en el Perú, el sector de trajes de baño y bikinis para damas no tiene una gran cantidad de empresas que puedan aprovechar esas grandes y potenciales oportunidades de venta hacia dicho mercado. Por tal motivo, la presente tesis busca determinar cuáles son los factores críticos de éxito que consolidan el posicionamiento comercial de la exportación de ropas de baño y bikinis para damas hacia el mercado francés. 


\section{CAPÍTULO I: MARCO TEORICO}

\subsection{Sector de Manufactura}

El sector manufactura a nivel mundial se ha desarrollado exponencialmente con el paso del tiempo, debido al avance de la tecnología y al desarrollo especializado de maquinarias para la creación de cada tipo de producto, instrumento y/o maquinaria para la fabricación de diversos productos que solicitan los consumidores cada vez más exigentes año tras año.

Las grandes industrias, no sólo tienen que fabricar productos aún más competitivos, sino, también crear valor agregado a sus productos y diferenciarlo de la competencia, logrando que los consumidores deseen adquirir el producto para la satisfacción de sus necesidades.

La manufactura ha pasado de ser desencantadora, con barreras de entradas elevadas, grandes inversiones de capital y diversidad de intermediarios en la cadena de suministro, a ser un gran ente de negocios de manufactura, donde fluye la información mediante la conectividad ubicua sin barreras de entrada, con los últimos avances de la tecnología y la política estatal, incluyendo la fabricación aditiva, la robótica y la ciencia de los materiales que han ampliado el panorama de lo que se puede fabricar y cómo hacerlo (Deloitte Development LLC.,2015).

El mercado va cambiando y las necesidades de los consumidores también, tal es así, que "todos estos desarrollos se están combinando con patrones de demanda cambiantes, para incrementar la fragmentación del mercado, apoyando una proliferación de fabricantes de productos 
derivados en la cadena de valor con contacto más directo con el consumidor" (Deloitte Development LLC.,2015,p.15).

\subsubsection{Industria Textil}

En los años 1850, lo que ahora es el territorio de los Estados Unidos de América, estaba dividido en dos: los Estados del Norte que estaban a favor de la abolición de la esclavitud y desarrollo de las industrias; y los Estados del Sur que estaban a favor de las prácticas del mercado de esclavos.

El 12 de abril de 1861, se da inicio a la Guerra de Secesión que duró cuatro años.

Los Estados del Norte bloquearon con las fuerzas navales el paso marítimo de los Estados del Sur que sólo los respaldaba las tropas del ejército, este bloqueo fue crucial para los intereses de los sureños ocasionándoles grandes pérdidas económicas, militares y políticas, que finalizó con su derrota. Esta situación trajo consigo la escasez de algodón, conocido como el hambre de algodón; lo que originó la expansión inglesa en la India, Sudán y Egipto por la codiciada materia prima, el incremento de la demanda de lana como una alternativa, y el desarrollo de potenciales fibras artificiales. (Pesok M.J.C., 2012). 


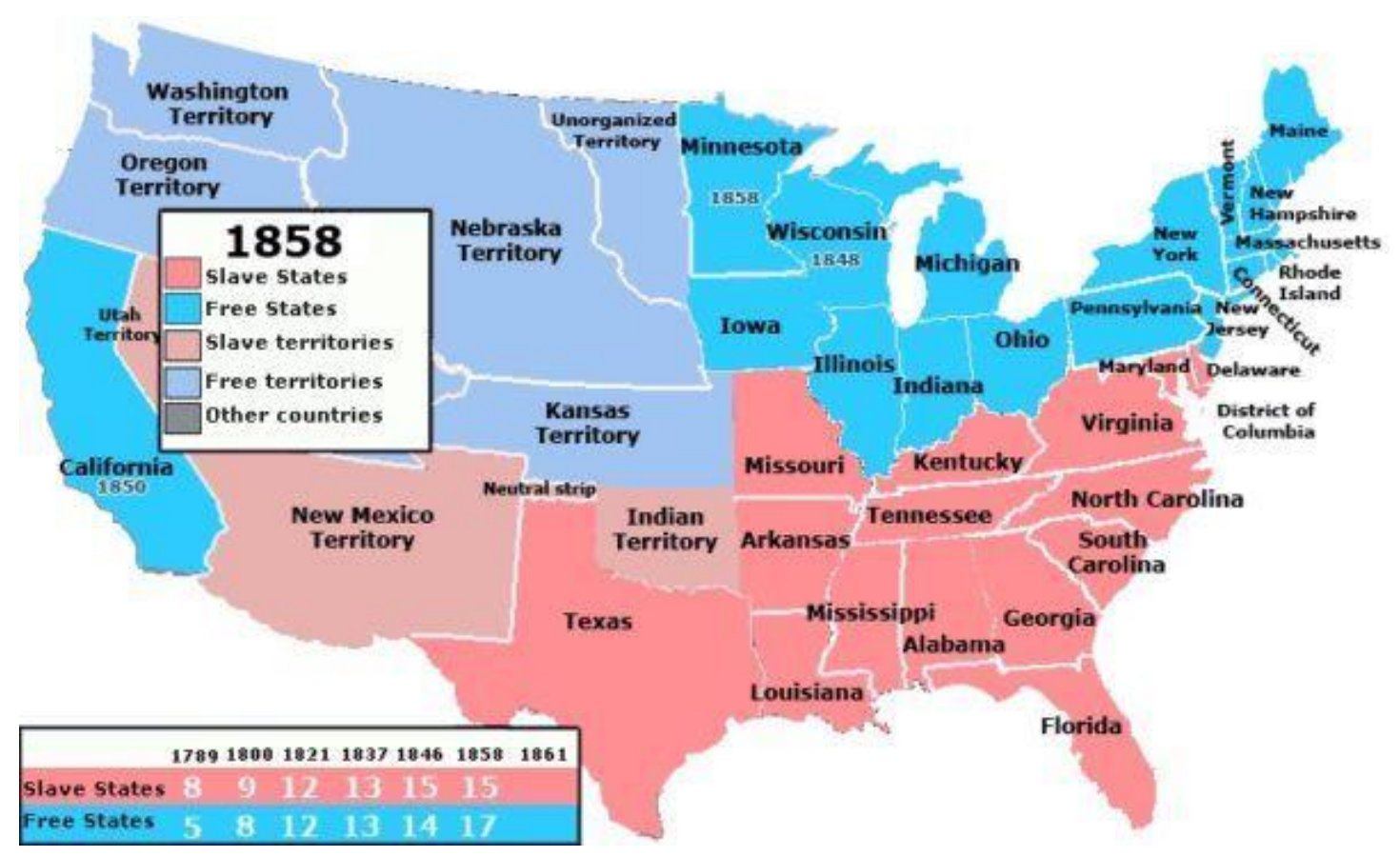

Figura 1. Mapa de los Estados y territorios libres y esclavos en el año 1858.

En 1889, Louis Marie Hilaire Bernigaud, Conde de Chardonnet de Grange, (industrial, químico francés pionero en la producción de fibras artificiales) da a conocer en la Exposición Internacional de París, un filamento de nitrocelulosa iniciándose el desarrollo de fibras artificiales.

Las primeras fibras artificiales que se elaboraron fueron las siguientes: rayón Chardonnet, rayón cuproamoniacal, rayón viscosa, rayones di y triacetato. Éstas se convirtieron en relevantes competidores del algodón al ser transformados en fibras discontinuas a raíz de la celulosa de la madera. En la actualidad subsisten con éxito la viscosa y el diacetato (Pesok M.J.C., 2012).

En 1935, el químico Wallace Carothers en el laboratorio de la empresa DuPont, creó la primera fibra sintética llamada Nylon, la cual entró al mercado en 1938, continuaron 
las fibras como poliéster, poliacrílicas, clorovinilicas, poliolefínicas, poliuretánicas. La mitad de las fibras textiles que se usan en el mundo son las fibras químicas, artificiales y sintéticas (Pesok M.J.C., 2012).

El punto de lycra contiene 82\% poliéster, 18\% elastán, de ancho de impresión tiene 145 centímetros, pesa 270gramos/m2, se estira en lo largo y ancho; es deshilachable y se puede realizar un dobladillo al borde (Textilfy).

Posteriormente en el siglo XX, con el desarrollo de las ciencias de química orgánica, la petroquímica y los estudios de la materia se produjeron fibras textiles de bajo peso molecular derivados del petróleo que por los procesos de polimerización se convierten en productos de alto peso molecular o polímeros. Estas fibras también son llamadas fibras sintéticas.

\subsubsection{Métodos de Producción de filamentos artificiales y sintéticos}

A continuación, se muestran los diversos procesos de polimerización de los filamentos artificiales y sintéticos para hallar la fibra adecuada. 


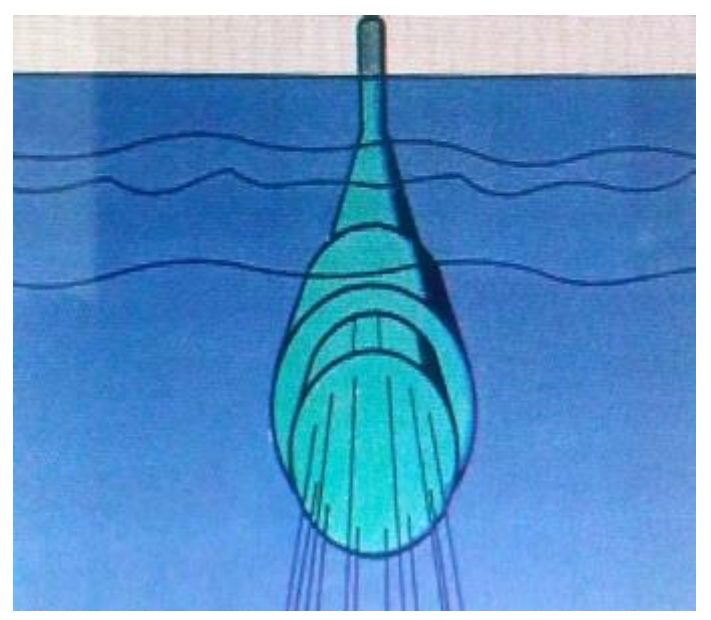

Figura 2. Método húmedo: método que por cambio de solvente el polímero se coagula y solidifica en una solución química. (Ej. Rayón viscosa, rayón cupro, algunas acrílicas, modacrílicas y elastano). Adaptado por Introducción a la tecnología textil por Pesok, M. J. C. (2012). Figuras reproducidas con la autorización de la "British Man-Made Fibers Federation").

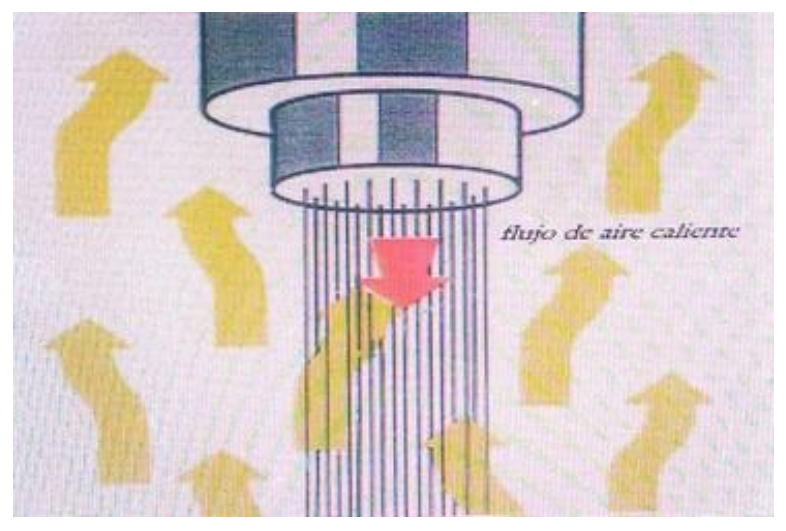

Figura 3. Método seco: es aquel que por evaporación del solvente en aire caliente el polímero en solución se solidifica (Ej. rayon acetato, triacetato, clorofibras, algunas acrílicas, modacrílicas y elastano). Adaptado por Introducción a la tecnología textil por Pesok, M. J. C. (2012). Figuras reproducidas con la autorización de la "British Man-Made Fibers Federation"). 


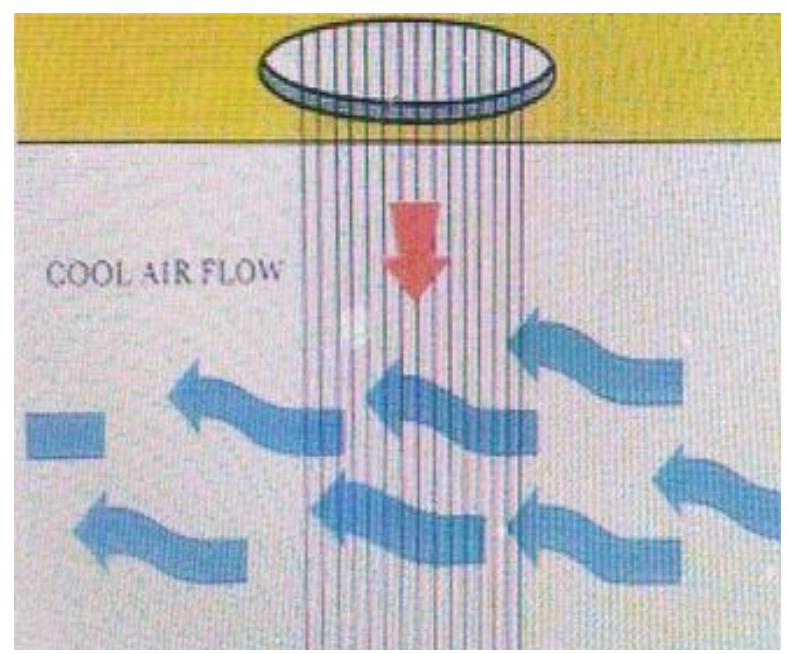

Figura 4. Método por fusión y solidificación: método que por enfriamiento el polímero fundido se solidifica (Ej. poliamidas, poliéster, polietileno, polipropileno). Adaptado por Introducción a la tecnología textil por Pesok, M. J. C. (2012). Figuras reproducidas con la autorización de la "British Man-Made Fibers deration").

\subsubsection{Ropas de Baño}

El traje de baño, es una prenda que cubre las partes íntimas, utilizada para nadar, tomar sol o bañarse en las playas, piscinas o ríos. Existen varios modelos, en el caso de las damas hay una prenda de una sola pieza que cubre desde el pecho a las ingles y tiene la espalda al descubierto. Una variedad al bañador tradicional, es el bikini, que consta de dos piezas separadas, $\mathrm{y}$ permiten un bronceado en la mayor parte del cuerpo. La prenda usada mayormente en las playas es el bikini aunque también existen bañadores que permiten el paso de la luz ultravioleta para un bronceado integral (Charles Frederick Worth, París 1995). 
Otra variedad moderna es el trikini, es un bañador híbrido entre un bañador tradicional y el bikini. Actualmente se encuentra de moda y produce un bronceado diferente y desigual al bikini.

\subsubsection{Cronología de la Ropa de Baño}

- A fines del siglo XVIII: nació la costumbre de bañarse, el rey Jorge III de Inglaterra fue el que apoyó el baño en las playas como una actividad social.

- En 1822: el primer baño de una dama fue realizado por la francesa duquesa de Berry, nuera de Carlos X, quien se bañó totalmente vestida en la playa de Dieppe en Francia.

- En 1890: se crea el primer bañador; que era una camisa-pantalón y medias, para hombre como para mujer.

- En 1915: ya no llevan media la vestimenta de playa, los hombres se bañan en pantalones cortos y las mujeres se ponen camisones y faldas para bañarse.

- En 1930: se crea el primer bañador femenino. Fabricado en lana con escote como las camisas y los pantalones cubrían los muslos. La prenda húmeda pesaba de tres kilos a más. 
- En 1946: el ingeniero Louis Réard crea el bañador el bikini. Pero recién en 1960 sería mayormente utilizado y conocido (Charles Frederick Worth, París 1995).

- En 1960: se crea la licra, este material hizo que se produjeran bañadores elásticos.

- En 1964: el estilista de California Rudi Gernreich crea el topless o monokini. Al comienzo era una prenda negra sostenida por dos tirantes que deja al descubierto el busto de las damas.

- En 1974: el genovés Carlo Ficcardi crea en Brasil la tanga.

- En el 2003 la australiana libanesa Aheda Zanetti crea en Australia el burkini, prenda especial para las damas musulmanas que no dejan su cuerpo al descubierto (Writing Alexis, España 2007).

\subsubsection{Telas apropiadas para Ropas de Baño}

\section{- Trajes de baño de algodón}

Los trajes de baño de algodón son cómodos y respiran, se sienten naturales contra la piel. Sin embargo, si el traje es cien por ciento algodón, hay grandes probabilidades de que se encoja después de algunos usos. 
También existe la posibilidad de que el color se destiña al ponerse en contacto con el cloro que se encuentra en el agua de la piscina. Estos trajes de baño no suelen calzar bien.

\section{- Nylon}

La tela de nylon se usa frecuentemente para hacer trajes de baño que respiren mejor, menos propensos a fruncirse o a desgarrarse. Seca más rápido que otros materiales, respira bien y no se rompe cuando se pone en contacto con el cloro u otros químicos. Sin embargo, puede desteñirse y raerse con el tiempo, pero en general, es la tela para trajes de baño más popular del mercado.

\section{- Polyester}

El polyester es un pariente del nylon, pero no es tan suave. Tiene muchas de las mismas características duraderas, pero no expulsa el agua o se seca tan rápidamente como el nylon. No suele estar presente en trajes de baño modernos, excepto en aquellos con mezcla de nylon y poliéster.

\section{- Lycra}

La lycra suele usarse para trajes de baño de competición porque calza muy bien y repele el agua rápidamente. Ya que la lycra se pega mucho más al cuerpo, no siempre es halagadora para gente con un tamaño y una forma corporal promedio (Writing Alexis, España 2007). 


\subsubsection{Panorama Económico Global del Comercio Internacional}

En el Informe del Fondo Monetario Internacional - FMI de octubre del 2017, hemos podido resaltar que en el 2016 se inició la actividad mundial, la cual cobró rapidez en el primer semestre del 2017, gracias al aumento del crecimiento de la demanda interna de las economías avanzadas y de China, y a un mejor desempeño de las grandes economías de los mercados emergentes. (FMI, 2017, p. 2)

Sin embargo, hemos podido revisar que en las economías avanzadas, el producto y la demanda interna crecieron con mayor rapidez en el primer semestre de 2017.

Asimismo, en la zona del Euro y Japón, el fortalecimiento del consumo privado, la inversión y la demanda externa crecieron con fuerza en el primer semestre del año 2017.

En la mayoría de las otras economías avanzadas, con la notable excepción del Reino Unido, el crecimiento sobresalió en el primer semestre de 2017, gracias a la contribución de la demanda tanto interna como externa. (FMI, 2017, p. 3)

Según la edición de abril del 2017 de las perspectivas de la economía mundial del Informe WEO (World Economic Outlook), el crecimiento mundial, está encaminado y se proyecta que el producto mundial crecerá 3.5\% en el 2017 y $3.6 \%$ en el 2018.

Sin embargo, en el caso de Estados Unidos, las proyecciones que se tienen son bajas a comparación de Japón y la Zona del Euro, quienes están en pleno crecimiento, presentando una actividad positiva en el 2017. 
En las economías avanzadas, la inflación se mantiene por debajo de las metas y moderada en particular en varias economías emergentes como Brasil, India y Rusia también que han retrocedido.

Dentro de esta fuerza económica que mueve al mundo, se encuentra el sector manufactura al cual pertenecen las grandes industrias de alimentos, bebidas, productos electrónicos, bienes de consumo masivo, bienes de capital, producción textil de vestir, etc.

Asimismo, el sector manufactura de textil, está generando grandes ingresos a varios países del mundo quienes han incrementado sus ingresos y a la vez generando empleo y diversos servicios que el rubro requiere.

En el 2017, China continúa siendo el gigante exportador textil del mundo, seguido en el segundo lugar se encuentra Bangladesh con un peso de US\$30 millones. Este país pobre del sudeste asiático cuenta con 4500 fábricas de las cuales un ciento cumple con la medidas de seguridad. El crecimiento de las exportaciones no ha traído consigo en estos dos casos el desarrollo económico de la fuerza laboral textil que es otro problema del sector, ya que, la subcontratación de la grandes marcas occidentales permitieron abaratar los costos de producción, y por ende, los salarios de trabajadores textiles. La 
explotación llega a tal punto que el salario mínimo al mes de 4000000 de obreros textiles es de US\$ 68 (AFP, abril 2017).

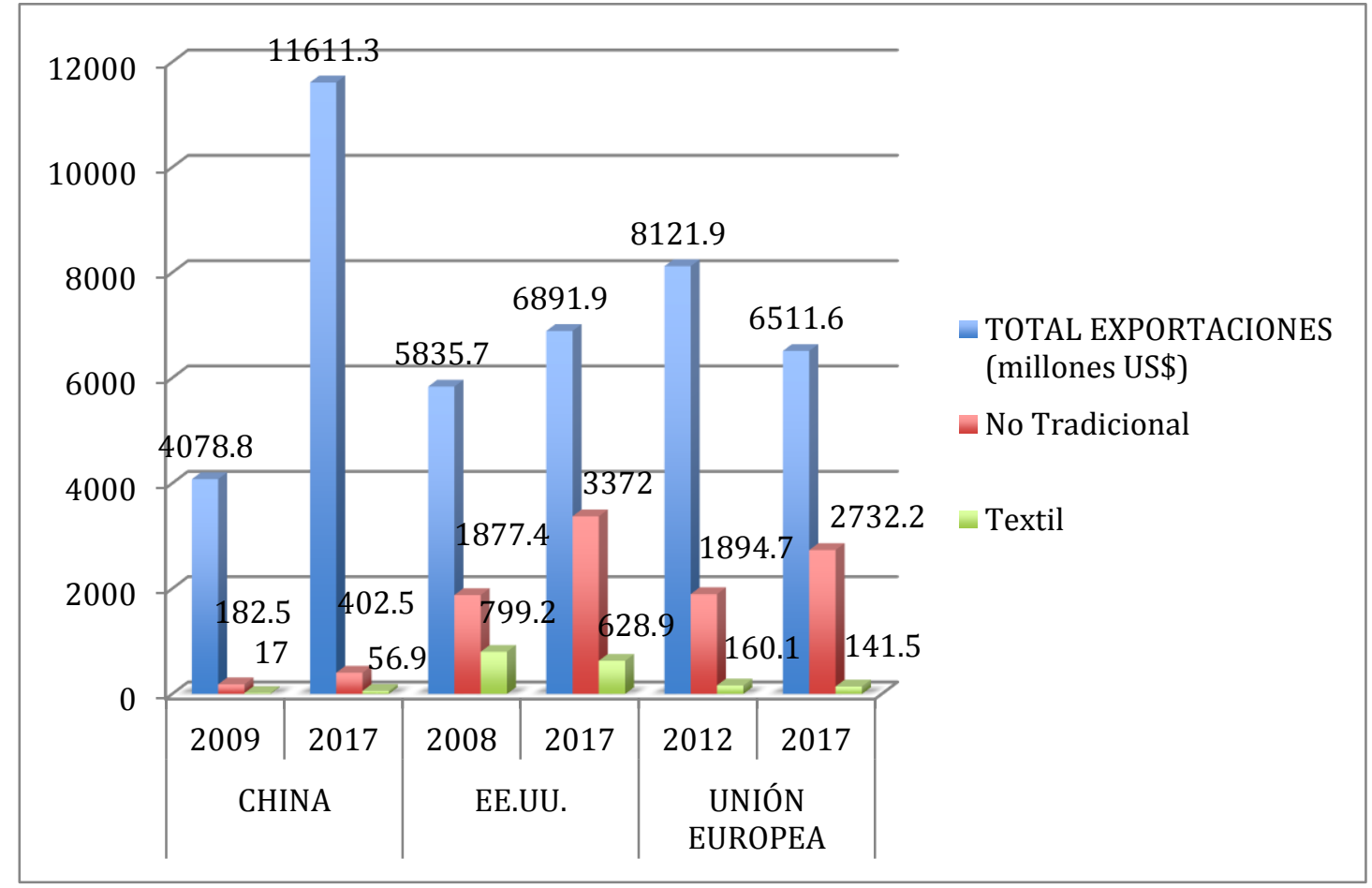


Figura 5. Exportaciones del Perú con EEUU, China y UE. Fuente. Elaboración propia con datos extraídos de Mincetur, BCRP, CCEX- CCL, Instituto de Economía y Desarrollo Empresarial de la Cámara de Comercio de Lima. Revista CCL Na 819.

En la figura 5, se puede apreciar el crecimiento de las exportaciones no tradicionales, dentro de las cuales se encuentra el creciente del rubro textil, el cual, no creció en determinado momento como se tenía esperado, debido a la crisis económicas de Estados Unidos y en la Zona Euro.

En el Perú, el Sector textil representa sólo el 2.17 \% del total de la exportaciones a la zona Euro al 2017, y el 9.13\% de exportaciones a Estados Unidos. Es todavía un sector al cual se necesita mayor inversión pública y privada, trabajo en conjunto de instituciones pública, privadas, empresarios y gremios industriales para mostrar mejores indicadores de emprendimiento, innovación e imposición de nuevas tendencias para la producción nacional de calidad que se comercia.

Dentro de este gran rubro textil se encuentra el sector industrial de producción de prendas de baño de fibras sintéticas para damas con partida arancelaria (6112410000), en el cual varios países han ido creciendo sus exportaciones. 


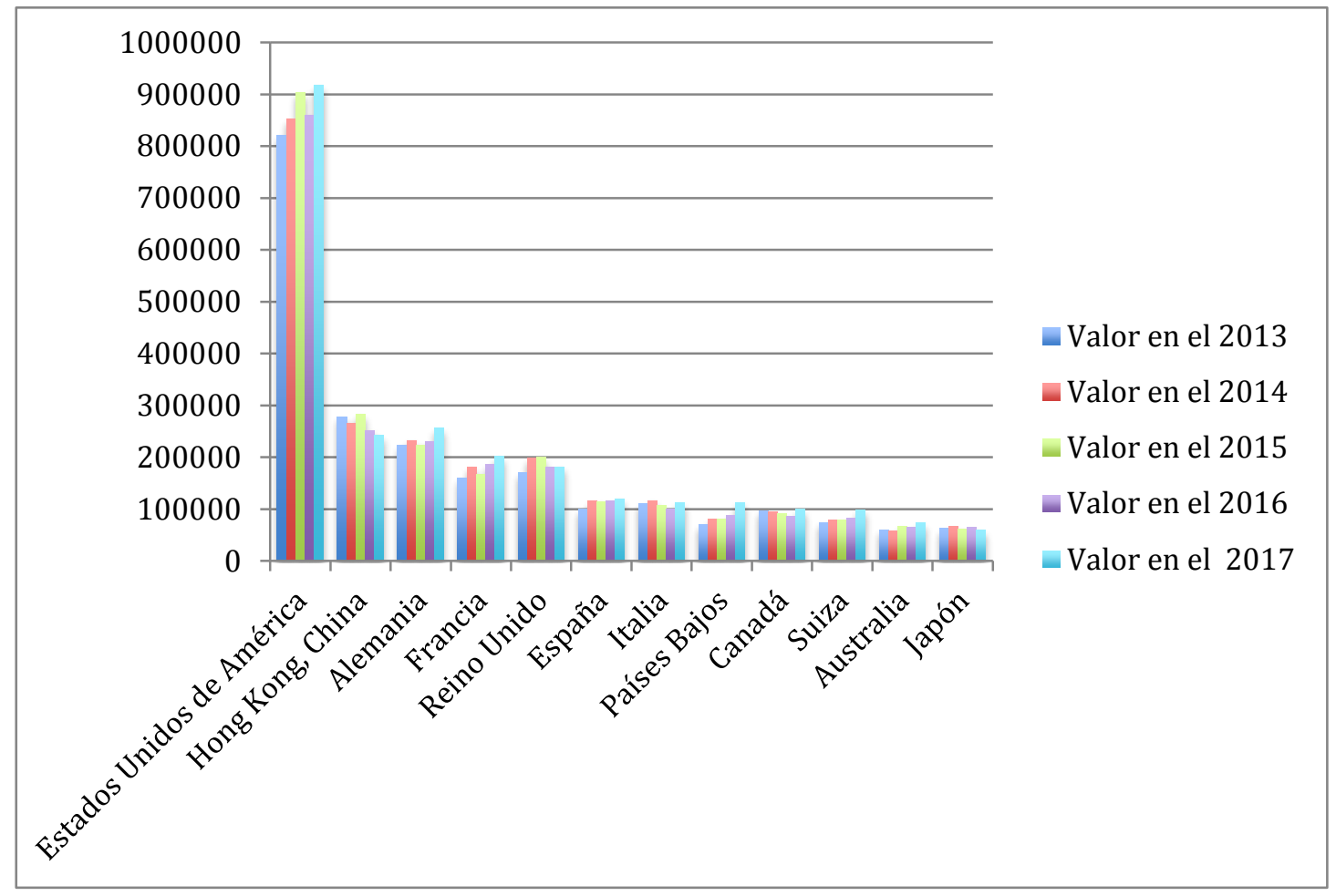

Figura 6: Principales Importadores Mundiales de ropas de baño y bikinis para damas del 2013 - 2017. Fuente: Elaboración propia adaptado de Trade Map.

En la figura 6, se puede apreciar que el mayor importador de prendas de baño es Estados Unidos, seguido de China, y países europeos como Alemania, Francia, Reino Unido, España e Italia, países que están a la vanguardia de la moda y tecnología textil. Estos países destacan por el amplio desarrollo comercial en el rubro textil, adquiriendo prendas para luego comercializarlos a nivel mundial. 


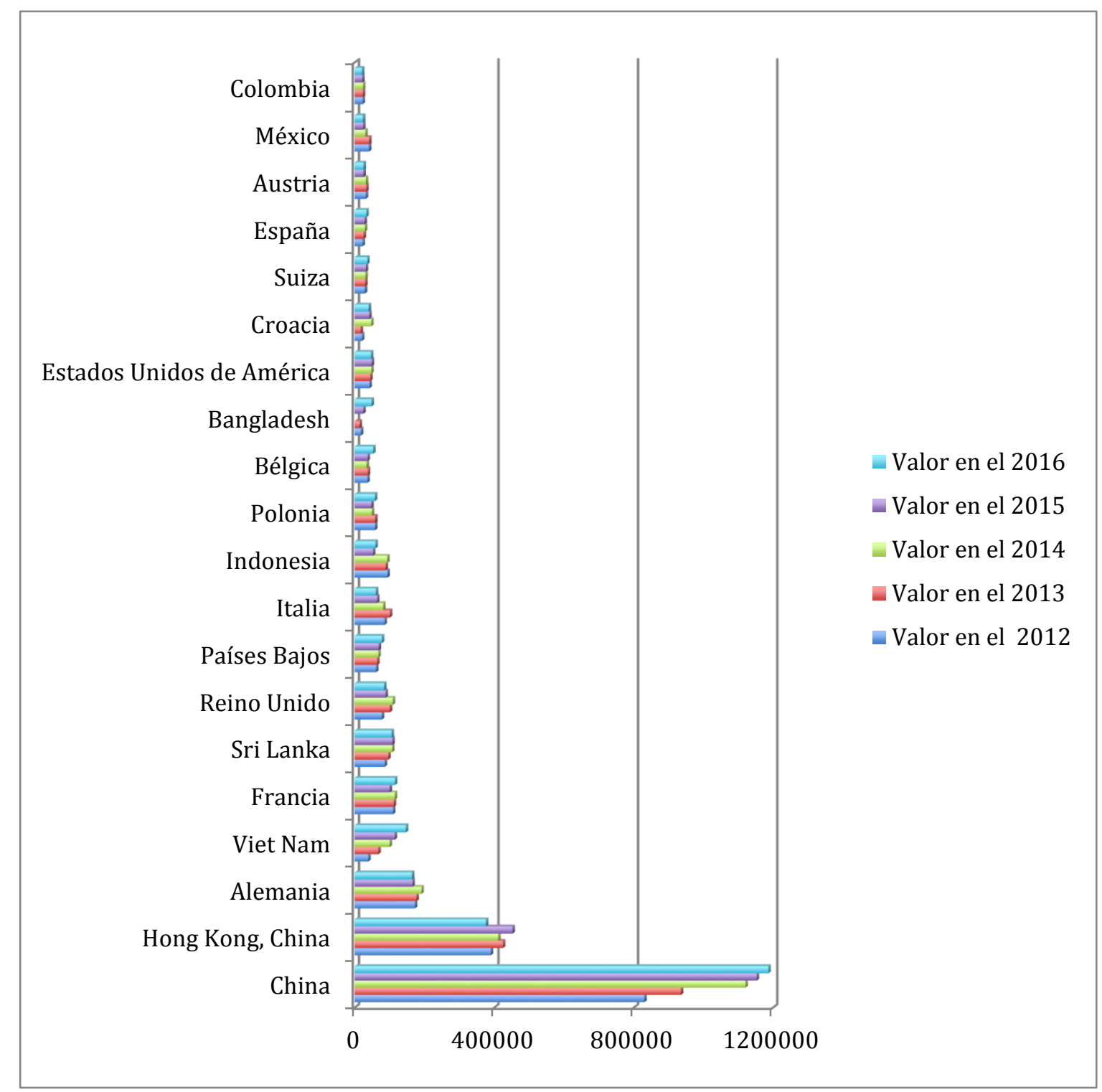

Figura 7: Principales exportadores mundiales de ropas de baño y bikinis para damas del 2012 - 2016. Fuente. Elaboración propia adaptado de Trade Map.

En la figura 7 se aprecia también a China como principal exportador, seguido de Hong Kong, Alemania, Vietnam y Francia. Se puede deducir de la comparación de la figura 6 y 7, que Hong Kong, Alemania y Francia, además de importar estas prendas también las exportan y colocan en diversos mercados atractivos del mundo. Es preciso 
mencionar, que muchas veces importan prendas de baño de muy buena calidad, pero sin marca y luego colocan sus propias marcas para exportarlos a otros destinos. El siglo XX trajo consigo la propagación de marcas dando la pauta de un formato que comenzó a imperar en este sector, estableciendo por un lado la concentración en las tareas de diseño del producto e imagen de la marca y por otro lado la tercerización de la confección a través de talleres (Lieutier,2010; Montero,2011; Dinorah Salgado \& Carpio Jorge, 2017).

Uno de los países que ha crecido y ha impactado al mercado internacional de bañadores es la industria colombiana que ha demostrado la reingeniería de sus procesos productivos con inversión en tecnología especializada, creación de estilos y tendencias innovadoras, y, organización de canales de distribución.

Un ejemplo de ello, es el negocio emprendedor de Catalina Álvarez, que como jugando empezó en la fábrica de ropa de su padre cuando encontró unos retazos de tela colorida y brillosa, se sentó en la máquina de su abuela a coser los pedazos de tela convirtiéndolos en bikinis. Ella se asoció con su amiga diseñadora y crearon Agua Bendita, empresa enfocada en un primer momento en diseños de plantas tropicales y aves; hoy exporta trajes de baño a 60 países obteniendo ganancias anuales de US\$ 7.5 millones, venden más de 150000 bikinis al año. El salto al estrellato sucedió cuando sus diseños aparecieron en la Revista Sports Illustrated, exclusiva de bañadores, que es como ganar un Oscar en el mundo de ropas de baño. Esta empresa cuenta con una fuerza laboral de 120 trabajadores y da trabajo indirecto a 900 personas. Su producción se desarrolla en Medellín, la ciudad textil de Colombia y los trabajos manuales en talleres de zonas rurales cercanas para los detalles finales. Agua Bendita vende al por mayor, 
también en sus tiendas en Colombia, tiene franquicias en distintos países y su sitio web. (BBC, Enero 2018)

La consultora de moda y ventas del comercio minorista del Grupo de Investigación de Mercado Euromonitor Marguerite LeRolland menciona que Agua Bendita ha obrado de manera inteligente creando una identidad visual reconocible, como una marca única (BBC, Enero 2018).

Para el 2018, el ingreso de tendencias prometedoras como las telas inteligentes con filtro UV, antibacteriales, biodegradables, repelentes o adaptaciones a cambios o condiciones medioambientales, muestra un panorama al que los emprendedores y grandes empresarios deberán aprovechar para satisfacer las necesidades de consumidores que buscan protección personal y del medio ambiente, de esa manera apoyar con responsabilidad social ambiental. Es la otra nueva tendencia que muestra un abanico de posibilidades en el pujante mundo textil.

Para el mercado estadounidense el sector de ropas de baño percibió ingresos de US\$17 600 millones en el 2015, según como informó Global Industry Analysts. Las damas estadounidenses consumen 4 trajes de baño en promedio al año, de acuerdo a lo mencionado por Statistic Brain en el 2012. Además el 220\% asegura que, les interesa lo que el público piense cuando vista una prenda de baño según la encuesta de Land's End (CNN, Junio 2017).

España es el sexto país del ranking textil que está representado en el EURATEX Confederación que representa los intereses de la Industria europea textil, con una cifra 
que asciende a 10371 millones de euros, 8005 empresas textiles y 128100 trabajadores seguidos de Italia, Turquía Alemania, Francia y Reino Unido.

La UE es el segundo exportador mundial de textiles y prendas de vestir con una facturación de 162000 millones de euros, 174100 empresas y 166 millones de trabajadores. Cada vez más mercados europeos apuestan por la inversión industrial textil no sólo exportando sino también importando productos de alta calidad de distintas partes del mundo.

Las grandes transnacionales textiles, realizan aperturas de tiendas fast-fashion en todos los países donde el comercio textil tiene auge. Existen capitales de la moda que gracias a su industria han logrado un amplio desarrollo como son París, Milán, Londres y Nueva York, se piensa en una quinta capital en la cual compiten México, Tokio, Berlín y Madrid.

\subsubsection{Panorama económico Francés}

Francia, es una república ubicada en Europa Occidental tiene cinco territorios de ultramar como Guyana Francesa, Guadalupe, Martinica, Mayotte y Reunión. París es su capital y la superficie metropolitana de Francia es de 551500 kilómetros cuadrados. Francia es un país moderno, líder entre los países europeos, miembro de la Unión Europea, NATO, G-8, G-20, del Consejo de Seguridad de las Naciones Unidas entre otras organizaciones multilaterales (Promperú, 2014). 
Dividida en 27 regiones, 22 se encuentran en la metrópoli y 5 en territorios ultramar, las regiones se dividen en 96 departamentos y 329 distritos; las divisiones más pequeñas se llaman cantones o comunas. París, Lyon, Niza, Estrasburgo, Toulouse, Burdeos son las ciudades principales (Promperú, 2014).

La moneda es el euro, el francés es el idioma oficial. Con respecto a la religión, el 83$88 \%$ es católica, el islam 5-10\% y los protestantes ocupan el 2\%. Francia es un país en el cual diferentes grupos culturales conviven como latinos, germanos celtas, norafricanos, eslavos, indochinos, norteamericanos y vascos. Con respecto a la población, ésta llegó a 66 millones de habitantes con la promedio de 40.6 años y una tasa de crecimiento de $0.47 \%$ al 2013 . Las edades oscilan entre $25-54$ un total de $38.9 \%$, entre 0-14 representan el 18.7\% de la población (Promperú, 2014).

En el 2016 la población aumentó a 67 millones de habitantes según CIA World Factbook (Promperú, 2017). 
FRANCIA

\begin{tabular}{|c|c|c|}
\hline \multicolumn{3}{|c|}{ FRANCIA } \\
\hline PIB Trim Per Capita [+] & IV Trim 2017 & $8.63 €$ \\
\hline PIB Mill. € [+] & 2017 & $2.287 .603 \mathrm{M} €$ \\
\hline PIB Per Capita [+] & 2017 & $34.10 €$ \\
\hline PIB Trim. Mill.€ [+] & IV Trim 2017 & $578.686 \mathrm{M} €$ \\
\hline Deuda total (M.€) [+] & 2016 & 2.150 .950 \\
\hline Deuda (\%PIB) [+] & 2016 & $96,50 \%$ \\
\hline Deuda Per Cápita [+] & 2016 & $32.11 €$ \\
\hline Déficit (M.€) [+] & 2016 & -75.893 \\
\hline Déficit (\%PIB) [+] & 2016 & $-3,40 \%$ \\
\hline \multicolumn{2}{|c|}{ COMERCIO } \\
\hline Exportaciones [+] & 2017 & $473.427,1 \mathrm{M} . €$ \\
\hline Exportaciones \%PIB [+] & 2017 & $20,70 \%$ \\
\hline Importaciones [+] & 2017 & $552.834,3 \mathrm{M} . €$ \\
\hline Importaciones \% PIB [+] & 2017 & $24,17 \%$ \\
\hline Balanza comercial [+] & 2017 & $-79.407,1 \mathrm{M} . €$ \\
\hline Balanza comercial \% PIB [+] & 2017 & $-3,47 \%$ \\
\hline Comercio Minorista Interanual [+] & Nov-17 & $1,9 \%$ \\
\hline
\end{tabular}

TABLA 1: Índices Macroeconómicos de Francia. Adaptado Datos Macro Países.

Francia es una de las diez economías más importantes del mundo donde sus habitantes presentan buena calidad de vida, debido a su PBI Per cápita de 34100 euros y se encuentra en el puesto 25 de 195 países del ranking de PBI Per cápita más alto.

Además, se encuentra en el puesto número 31 de 190 países en los que se brinda facilidad de hacer negocios. Las calificadoras de riesgo más importantes como Moody's en setiembre del 2015, califica a Francia como Aa2, S\&P en noviembre del 2013 califica como AA y Ficth en enero 2018 lo califica como AA son indicadores que muestran un país con una economía estable, rentable, con perspectivas de crecimiento, que se ve reflejado en el progreso de la población y los ingresos que perciben. 
Francia muestra comportamiento de apertura al mercado internacional, tal es así, que la facilidad de crear negocios allí es importante de acuerdo a sus políticas y acuerdos comerciales que establecen la Unión Europea con diversos países en todo el mundo. En el caso de Perú, entró en vigencia el Tratado de Libre Comercio a partir del 01 de marzo del 2013.

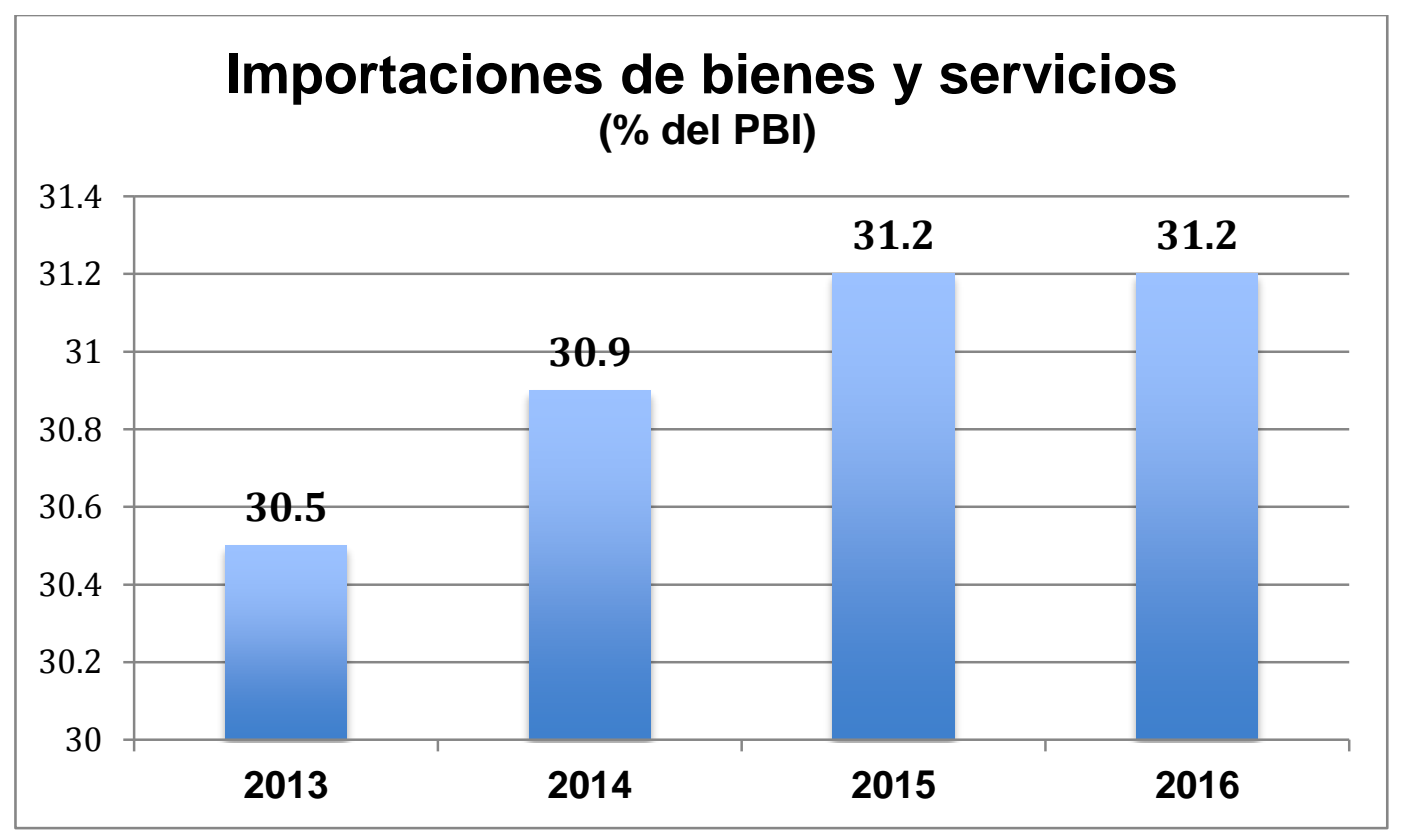

Figura 8: Porcentaje de Importaciones de Bienes y Servicios respecto al PBI Francia. Elaboración propia con datos tomados de Indicadores de Desarrollo Mundial del Banco Mundial.

La figura 8, muestra que más del 30\% del PBI es equivalente a las importaciones anuales que realiza Francia, es un gran porcentaje que destina Francia para adquirir productos y servicios en todo el mundo. 


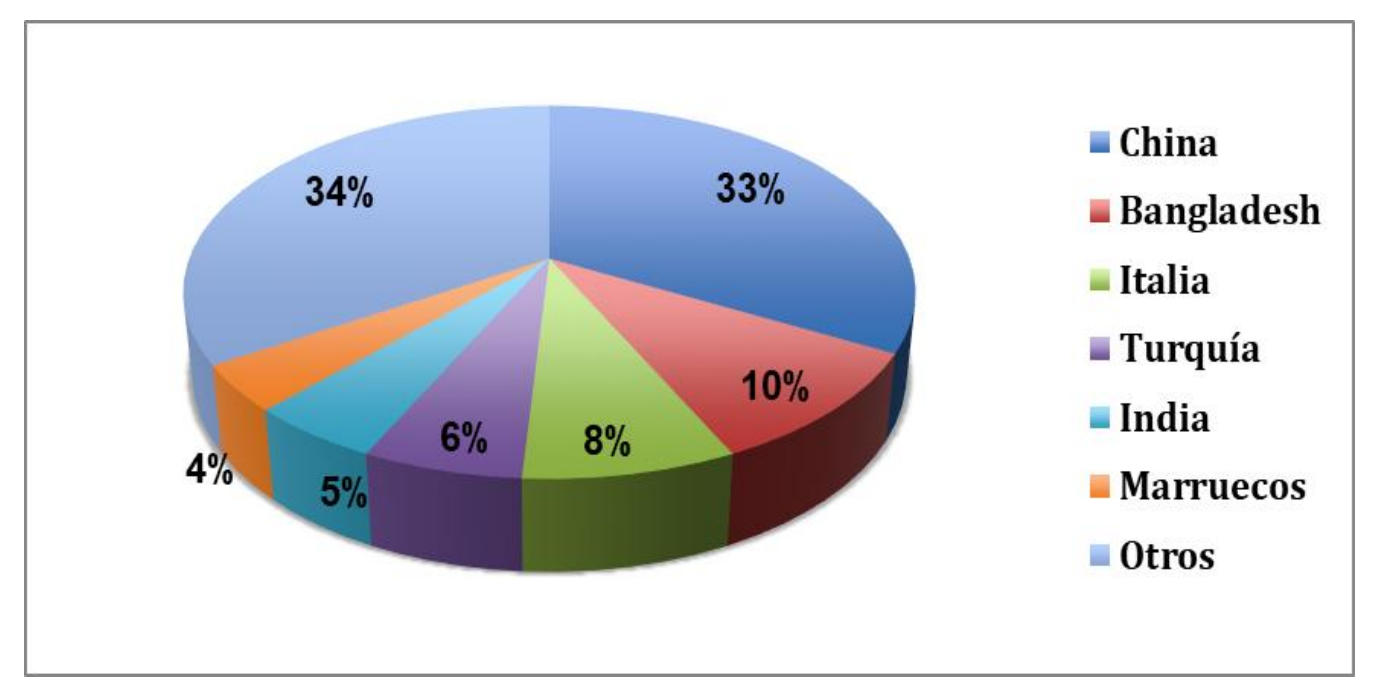

Figura 9. Principales proveedores de Francia Elaboración propia. Fuente: TradeMap

En la figura 9, se muestra las importaciones anuales de prendas de vestir del 2011 al 2015, presentando una reducción en el 2012 debido a la crisis financiera en la Zona Euro. Los principales países proveedores son China y un grupo de países que destacan en el rubro textil como Colombia, Perú y Brasil, etc.

Es importante mencionar, que actualmente las relaciones comerciales entre Perú y la Unión Europea se enmarcan en un Acuerdo Comercial Multipartes, el cual entró en vigor el 01 de marzo del 2013. Mediante este acuerdo las exportaciones del Perú 
con Unión Europea, específicamente con Francia, tienen una preferencia de 100\% para el sector textil en trajes de baño, por lo que el arancel que pagan es cero.

De otro lado, debemos destacar que el sector textil francés es un mercado muy competitivo, maduro y con fuerte dinamismo de concentración ya que, es un mercado mil veces más grande que hace dos décadas y los consumidores tienen mayor capacidad adquisitiva.

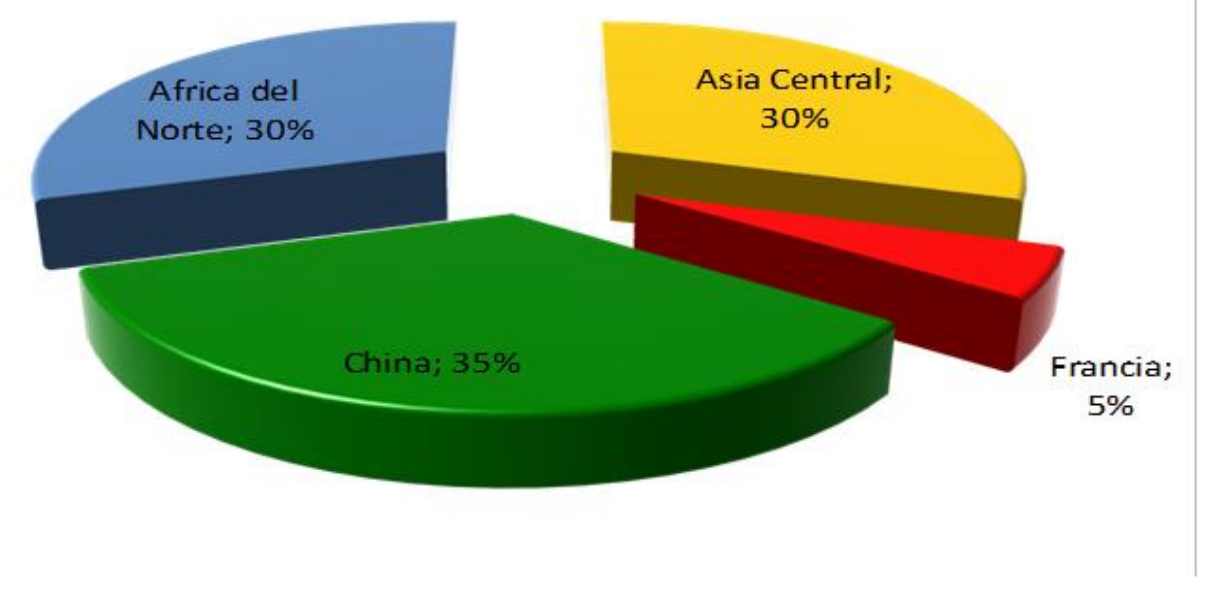

Figura 10. Distribución de la Producción de Francia del 2013. Adaptado por Estudio de mercado de Moda en Francia de ropas de Baño PROCOLOMBIA (2013) Fuente:Maison du prêt à porter.

Asimismo, hemos podido investigar que Francia sólo produce el 5\% del total de lo que consume en la industria textil, el porcentaje restante es importado de otros países (Procolombia - Maison du pret a porter, 2013).

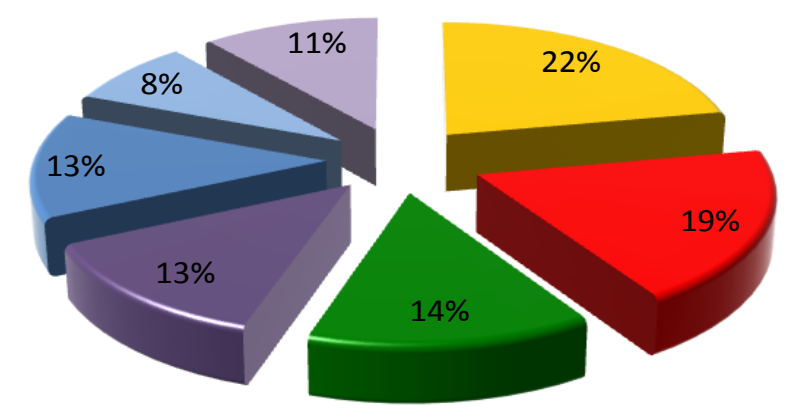


Figura 11. Canales de Distribución de Francia en el 2013. Adaptado por Estudio de mercado de Moda en Francia de ropas de Baño PROCOLOMBIA (2013) Fuente: Cálculos Proexport.

De la misma manera, los consumidores en mayor porcentaje adquieren sus prendas de los canales de distribución tales como hipermercados, supermercados, grandes almacenes y cadenas especializadas textiles.

Cabe resaltar, que los franceses gastan hasta 7800 millones de euros anuales solamente en trajes de baño y accesorios playeros, debido a que, París es la capital de la moda y los grandes desfiles del sector textill.

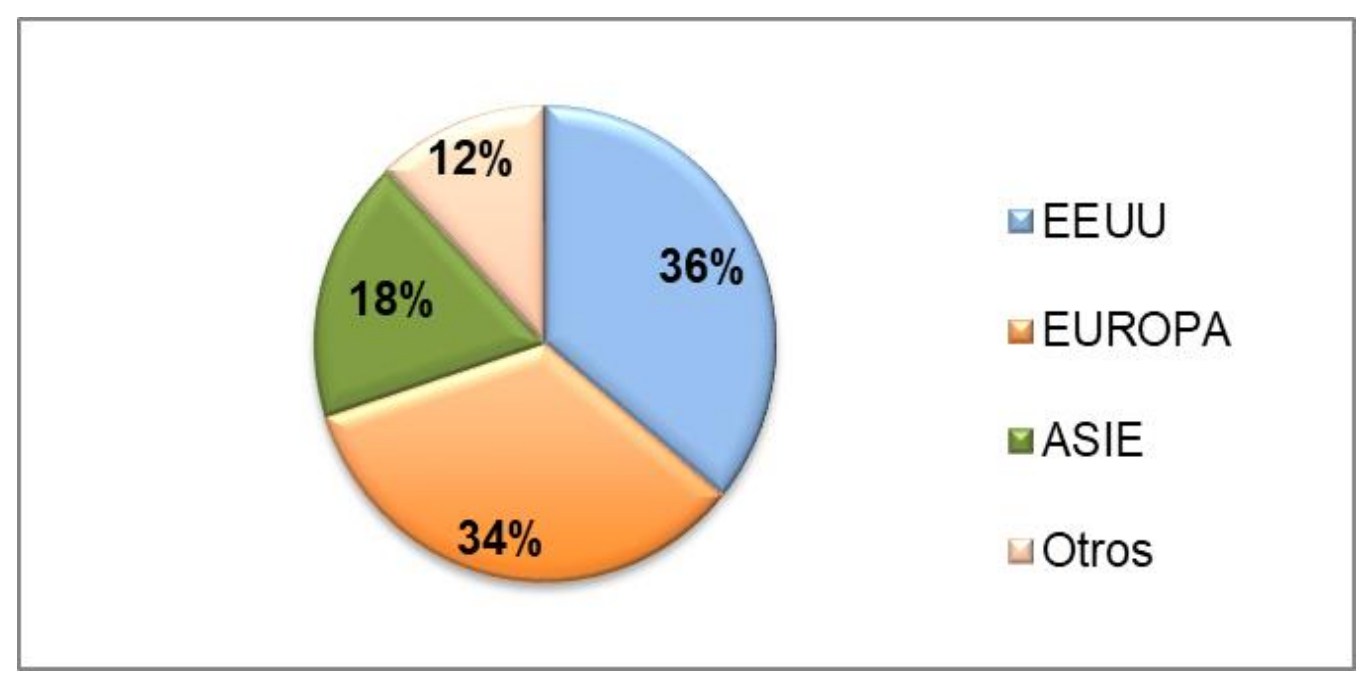


Figura 12. División del mercado mundial. Adaptado por Estudio de mercado de Moda en Francia de ropas de Baño PROCOLOMBIA (2013) Fuente: Creations Lingerie.

La figura 12 da a conocer que Europa tiene un tamaño muy cercano al mercado de trajes de baño de Estados Unidos. Ambos son los que más importan trajes de baño sumando un total $70 \%$ del mercado mundial

Francia, se caracteriza por tener lugares formidables de paradisiacas playas que lo hacen atractivo a la vista de sus habitantes y turistas de todo el mundo; y es el segundo país después de Estados Unidos que cuenta con una alta cantidad de consumidores de trajes de baño en todo el mundo.

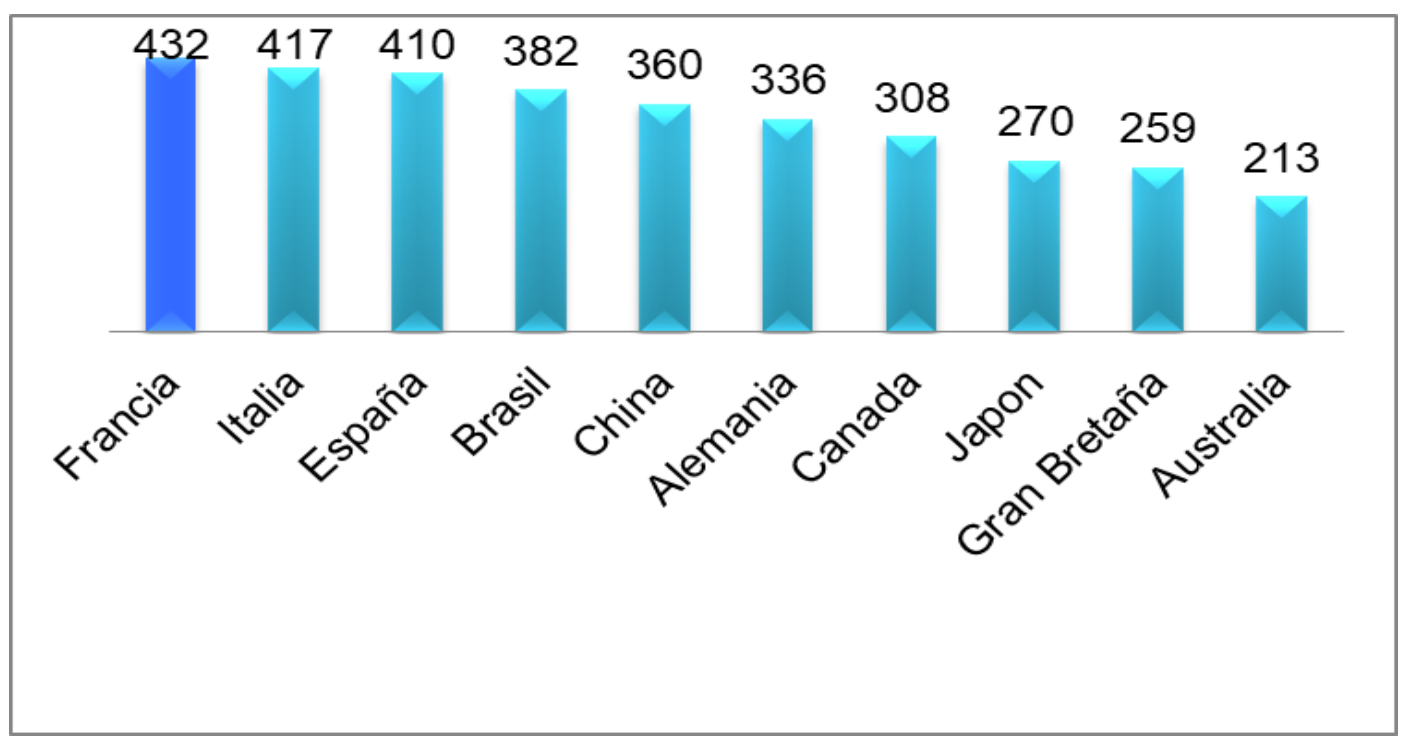

Figura 13. Principales consumidores de Trajes de Baño fuera de USA expresado en millones de euros. Adaptado por Estudio de mercado de Moda en Francia de ropas de Baño PROCOLOMBIA (2013). Fuente: Estudio de mercado de Mode City realizado por NPD Group. 
Francia es el segundo país después de Estados Unidos mayor consumidor de trajes de baño en todo el mundo.

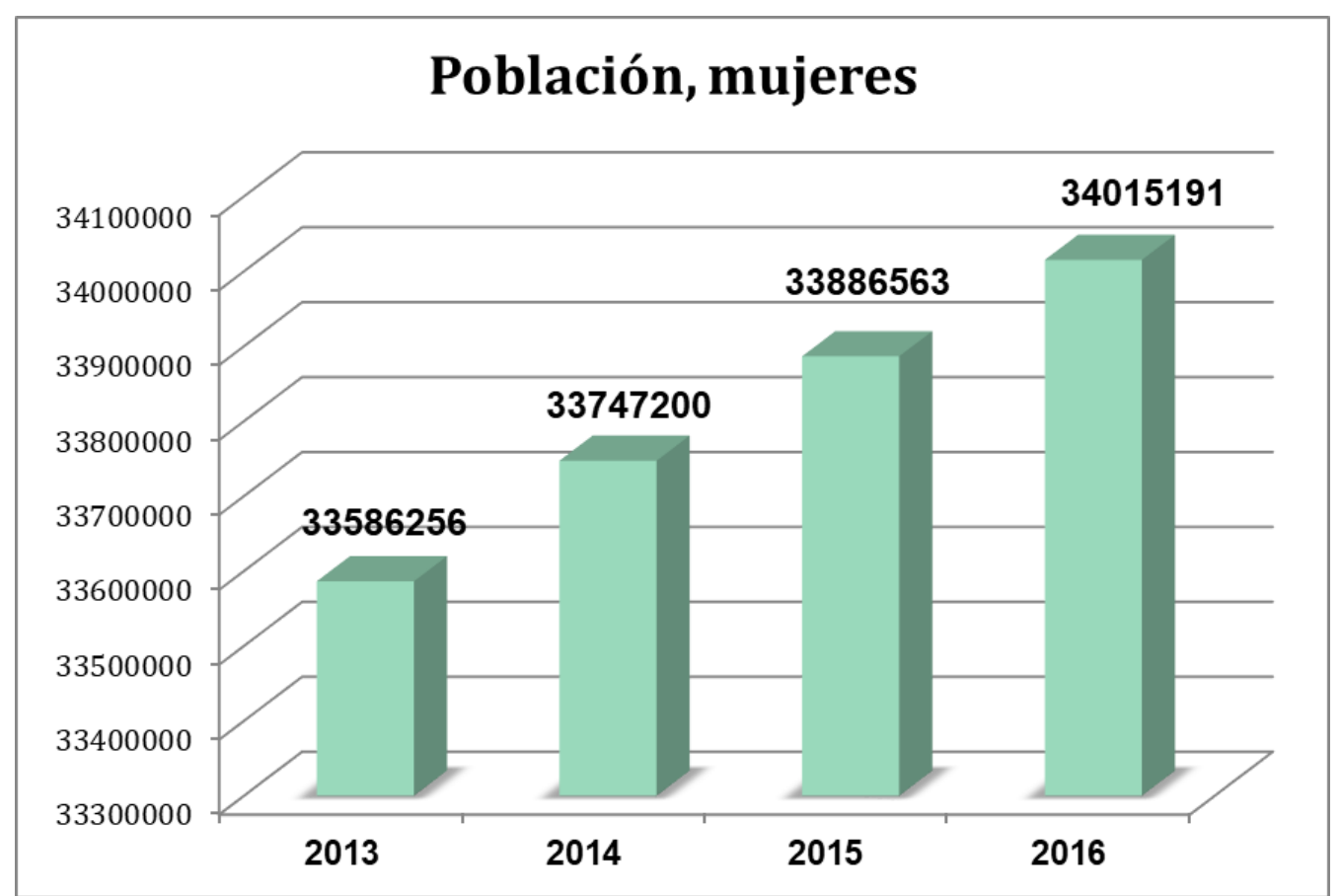

Figura 14. Población de género femenino en Francia. Elaboración propia con datos tomados de Indicadores de Desarrollo Mundial del Banco Mundial.

La figura 14 nos muestra que con el paso del tiempo la población de género femenino va en aumento y casi la mitad de población es de género femenino.

Los tiempos han cambiado, hoy en día las mujeres tienen otras responsabilidades, mayor poder adquisitivo, el salir de compras es una actividad que realizan entre otras tareas de su vida diaria. Hay tendencia de comprar en compañía de amigas, les gusta buscar, comparar, son más exigentes que los hombres y se toman su tiempo para ello (Underhill P., 2000). 
Según el filósofo francés Lipovetsky las mujeres no sólo buscan estar a la moda por diferenciarse del resto o por mantener un estilo de vida, sino como una manera de mejorar su estado de ánimo, cuando se sienten deprimidas o desmoralizadas, buscan ir de compras, a la peluquería o al spa; de esa manera sienten la sensación de convertirse en otras personas rejuvenecidas, dándose otra oportunidad para ellas mismas transformándose en un fenómeno terapéutico (Lipovetsky, Gilles, 2012).

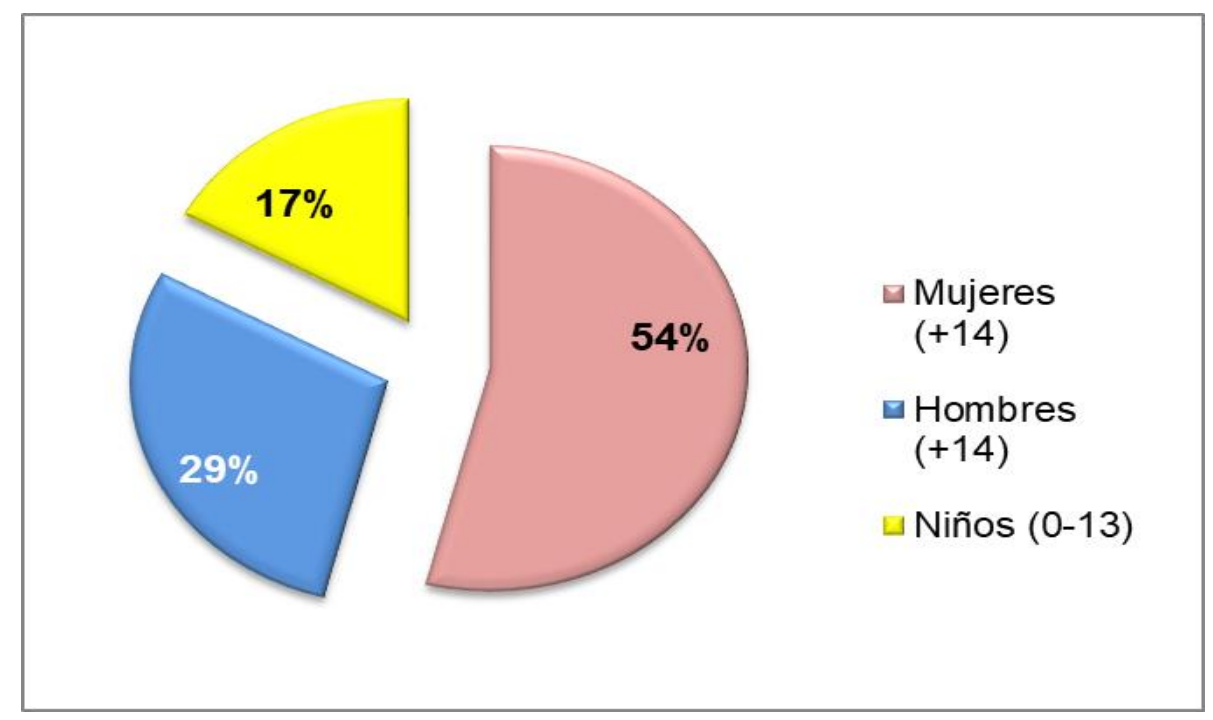

Figura 15. Ventas por género y Niños. Adaptado por Estudio de mercado de Moda en Francia de ropas de Baño PROCOLOMBIA (2013). Fuente: Estudio de mercado de Mode City realizado por NPD Group.

En la figura 15 detalla que el mayor porcentaje de compras en Francia es realizado por las mujeres con un 54\%. Al momento de realizar la compra, las francesas no se fijan en las promociones. 
Asimismo, según el Estudio de Mercado Mode City NPD Group detalla que las francesas compran al menos un traje de baño al año, donde el $24 \%$ de las mismas superan en promedio el valor de 50 euros.

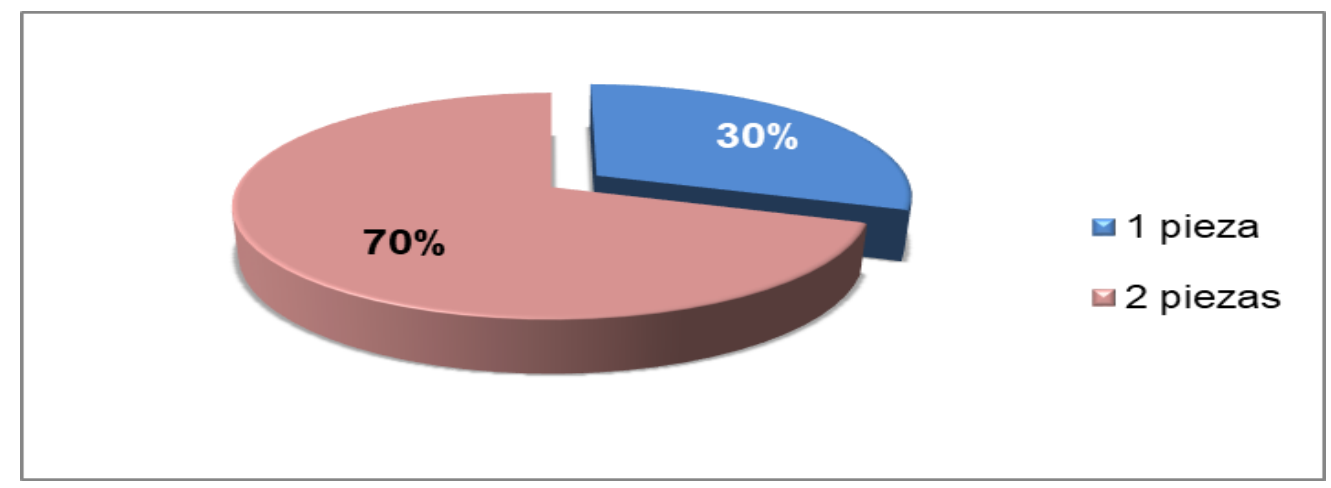

Figura 16. Ventas por tipo de traje de baño. Adaptado por Estudio de mercado de Moda en Francia de ropas de Baño PROCOLOMBIA (2013). Fuente: Estudio de mercado de Mode City realizado por NPD Group.

El traje de baño más vendido en Francia es el bikini (2 piezas) con un $70 \%$.

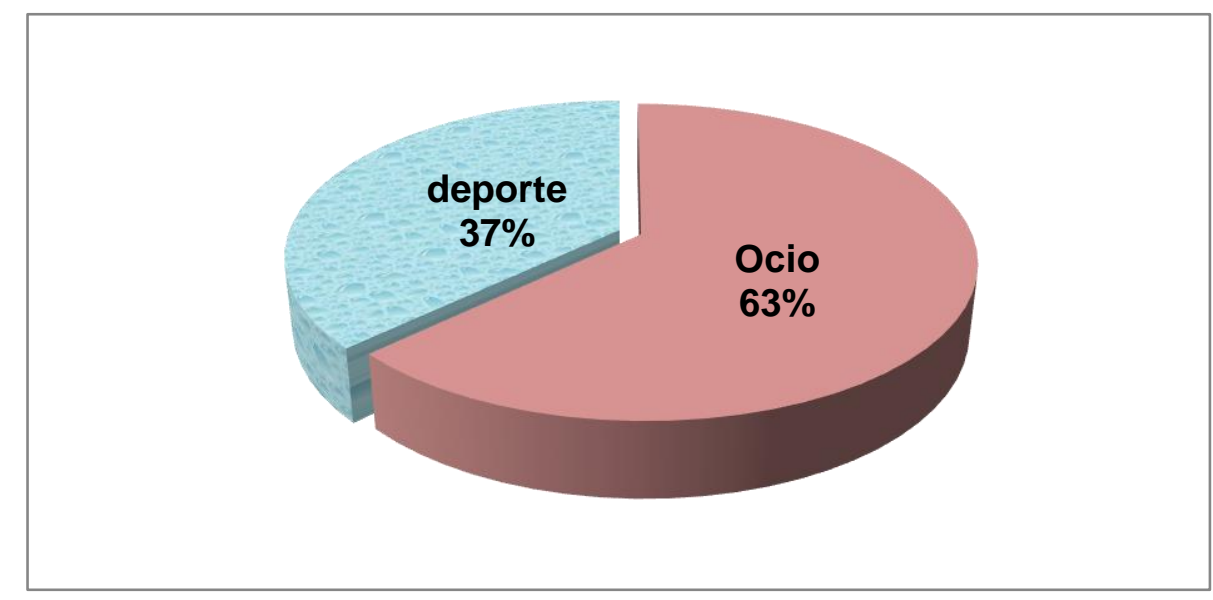

Figura 17. Finalidad de compra de traje de baño. Adaptado por Estudio de mercado de Moda en Francia de ropas de Baño PROCOLOMBIA (2013). Fuente: Estudio de mercado de Mode City realizado por NPD Group.

Bikini triangular Shores Strapless Una pieza Trikini Tankini


Figura 18. Diseños utilizados. Adaptado por Estudio de mercado de Moda en Francia de ropas de Baño PROCOLOMBIA (2013). Fuente: http://www.creations-lingerie.com/

Los meses de verano en Francia son desde junio a setiembre; estos son los meses en donde se realiza el $45 \%$ de las ventas.

Cabe mencionar que Francia es el segundo país que cuenta con la mayor cantidad de piscinas en el mundo, por lo que cuenta con alta demanda de adquisición de las prendas de ropas de baño y bikinis. Además, siendo Francia el país de la moda, las francesas son las que más compran en toda Europa

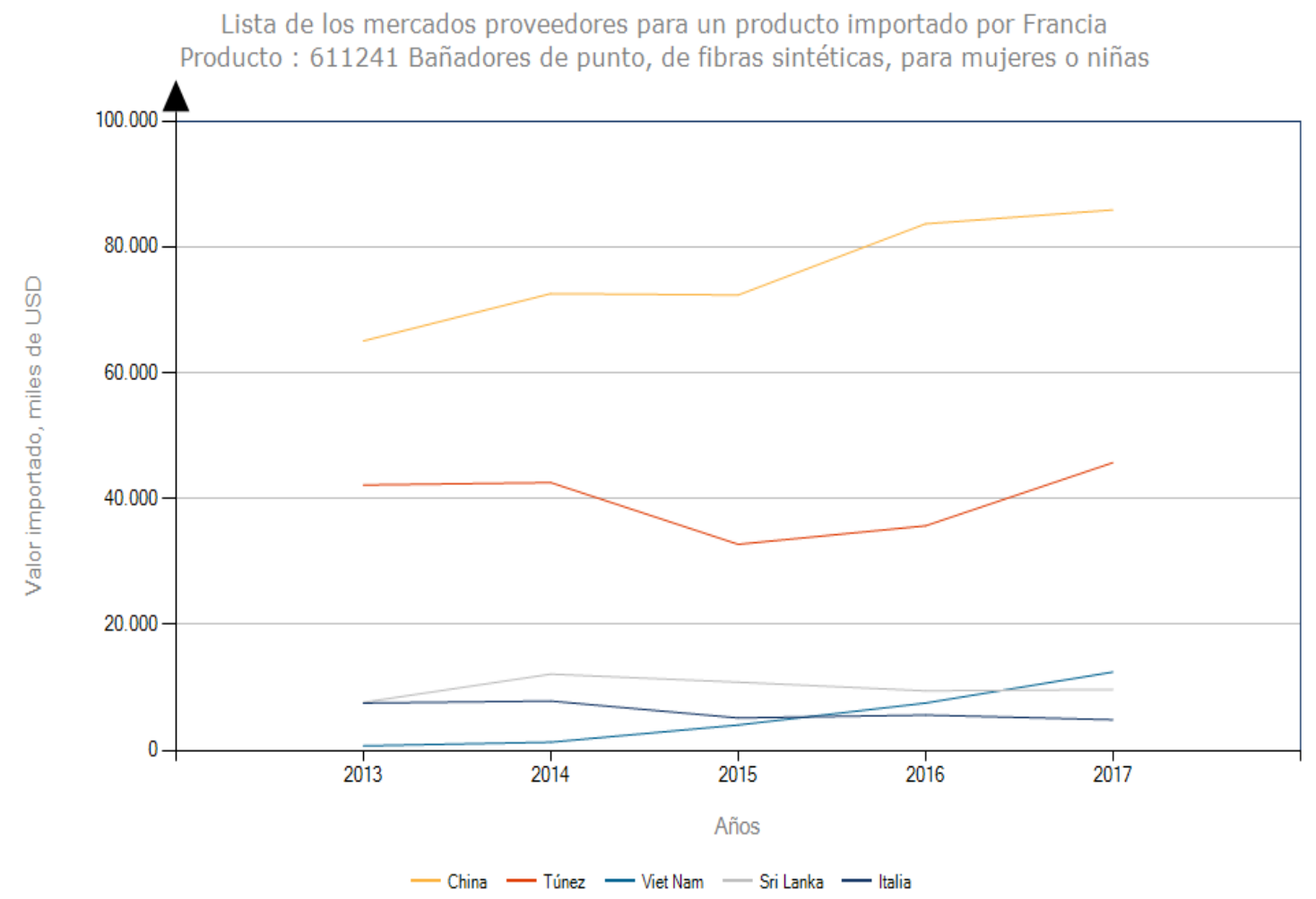

Figura 19. Principales proveedores de Francia de bañadores de fibra sintética para damas 2013 - 2017 Fuente: TradeMap. 
China es el primer proveedor de Francia, seguido de Túnez y Vietnam.

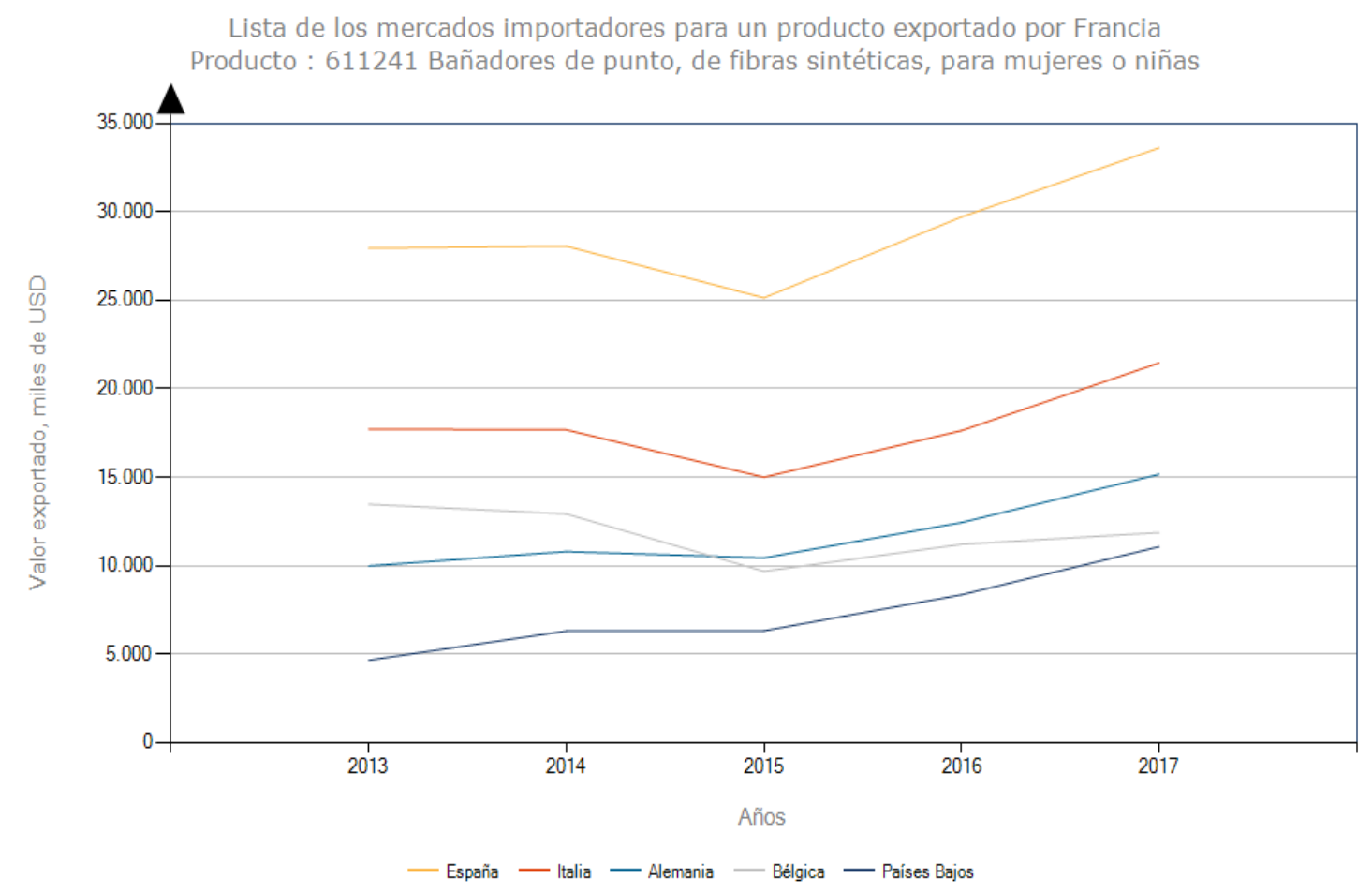

Figura 20. Mercados importadores para el producto bañadores de fibra sintética exportado por Francia del 2013 al 2017. Fuente: TradeMap.

Los principales importadores de Francia son los países de Unión Europea que lo rodean.

Es decir, Francia importa grandes cantidades de prendas de baño para abastecer al mercado europeo.

\subsubsection{Panorama económico del Perú}

El Perú es uno de los países más importantes de Latinoamérica, por contar con una variedad de climas, una enorme extensión territorial, importantes recursos naturales y solidos antecedentes económicos e industriales. Actualmente, es uno de los países considerados como principales mercados emergentes del mundo, cuenta con una 
importante y reciente historia de estabilidad económica fundamentando un crecimiento anual promedio interrumpido de 5.1\% de su PBI durante los últimos 16 años interrumpidos. (Guía de Negocios e Inversión Perú 2016-2017; 2016)

El Perú está localizado en la costa oeste central de Sudamérica, limitada con el Océano Pacifico al oeste, con Chile al sur, con Brasil y Bolivia al este y con Colombia y Ecuador al norte. Con una extensión territorial de 1,285,215,.60 Km2, el Perú es el tercer país más extenso de Sudamérica después de Argentina y Brasil, y se puede dividir en tres regiones naturales: Costa, Sierra y Selva. (Guía de Negocios e Inversión Perú 20162017; 2016)

La economía peruana parece tener unas excelentes perspectivas de desarrollo, debido a su enorme dotación de recursos naturales, apertura al exterior, y estabilidad macroeconómica y política. Bajo supuestos, ello debería ser suficiente para crecer a tasas cercanas al 4-5\% a medio plazo. En horizontes temporales más cortos, la coyuntura de sus socios comerciales y la política monetaria de EEUU, y los propios altibajos de la coyuntura peruana (en particular, el ritmo de ejecución de los grandes proyectos de inversión) jugarán también un papel importante. (Guía Perú 2017, 2027) 


\begin{tabular}{|c|c|c|c|c|c|c|c|c|}
\hline \multicolumn{2}{|c|}{$\begin{array}{c}\text { Año / } \\
\text { Trimestre }\end{array}$} & $\begin{array}{c}\text { Producto } \\
\text { Bruto } \\
\text { Interno }\end{array}$ & $\begin{array}{c}\text { Gasto de } \\
\text { Consumo } \\
\text { Final } \\
\text { Privado }\end{array}$ & $\begin{array}{c}\text { Gasto de } \\
\text { Consumo } \\
\text { de } \\
\text { Gobierno }\end{array}$ & $\begin{array}{c}\text { Formación } \\
\text { Bruta de } \\
\text { Capital }\end{array}$ & $\begin{array}{c}\text { Formación } \\
\text { Bruta de } \\
\text { Capital Fijo }\end{array}$ & $\begin{array}{c}\text { Exportacio } \\
\text { nes }\end{array}$ & Importaciones \\
\hline \multicolumn{2}{|c|}{2013} & 543,670 & 343,095 & 62,514 & 138,988 & 137,524 & 134,847 & 135,774 \\
\hline \multirow{4}{*}{ 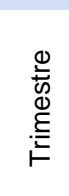 } & I & 126,849 & 81,510 & 14,057 & 31,948 & 30,351 & 30,776 & 31,442 \\
\hline & II & 137,086 & 87,018 & 14,829 & 36,138 & 33,758 & 32,214 & 33,113 \\
\hline & III & 136,774 & 87,470 & 15,794 & 34,196 & 36,341 & 36,137 & 36,823 \\
\hline & IV & 142,961 & 87,097 & 17,834 & 36,706 & 37,074 & 35,720 & 34,396 \\
\hline \multicolumn{2}{|c|}{2014} & 570,868 & 366,926 & 72,722 & 140,564 & 139,891 & 128,869 & 138,213 \\
\hline \multirow{4}{*}{ 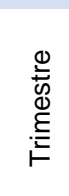 } & I & 134,799 & 88,217 & 16,138 & 32,837 & 32,520 & 31,055 & 33,448 \\
\hline & II & 144,392 & 93,609 & 16,364 & 37,910 & 34,267 & 30,962 & 34,453 \\
\hline & III & 142,766 & 92,904 & 18,867 & 33,364 & 35,446 & 33,082 & 35,451 \\
\hline & IV & 148,911 & 92,196 & 21,353 & 36,453 & 37,658 & 33,770 & 34,861 \\
\hline \multicolumn{2}{|c|}{2015} & 604,802 & 394,022 & 79,800 & 146,623 & 139,550 & 128,664 & 144,307 \\
\hline \multirow{4}{*}{ 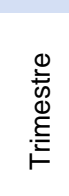 } & I & 140,085 & 93,817 & 17,117 & 35,053 & 32,078 & 28,484 & 34,386 \\
\hline & II & 153,369 & 100,213 & 18,373 & 39,533 & 33,191 & 30,659 & 35,409 \\
\hline & III & 150,518 & 100,251 & 20,485 & 33,448 & 35,429 & 33,494 & 37,160 \\
\hline & IV & 160,830 & 99,741 & 23,825 & 38,589 & 38,852 & 36,027 & 37,352 \\
\hline \multicolumn{2}{|c|}{2016} & 646,803 & 419,339 & 86,951 & 142,960 & 138,879 & 145,131 & 147,578 \\
\hline \multirow{4}{*}{ 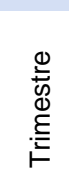 } & I & 152,363 & 100,905 & 20,496 & 35,727 & 33,108 & 30,997 & 35,762 \\
\hline & II & 161,319 & 106,198 & 20,770 & 36,792 & 33,284 & 32,348 & 34,789 \\
\hline & III & 161,912 & 106,602 & 21,765 & 32,358 & 34,980 & 39,149 & 37,962 \\
\hline & IV & 171,209 & 105,634 & 23,920 & 38,083 & 37,507 & 42,637 & 39,065 \\
\hline \multicolumn{2}{|c|}{2017} & 689,277 & 441,123 & 92,435 & 144,277 & 141,992 & 167,243 & 155,801 \\
\hline \multirow{4}{*}{ 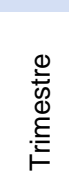 } & I & 161,518 & 106,332 & 19,901 & 34,168 & 31,854 & 37,713 & 36,596 \\
\hline & II & 172,031 & 112,165 & 22,158 & 35,603 & 32,923 & 39,324 & 37,219 \\
\hline & III & 174,022 & 112,666 & 23,346 & 33,512 & 36,884 & 44,656 & 40,158 \\
\hline & IV & 181,706 & 109,960 & 27,030 & 40,994 & 40,331 & 45,550 & 41,828 \\
\hline
\end{tabular}

TABla 2. Producto Bruto Interno por tipo de Gasto 2013 al 2017 expresado en millones de soles. Fuente: Informe Técnico INEI (2017)

El valor real de las exportaciones FOB en el 2017, totalizó US\$ 44983 millones, monto superior en 11,3\% al valor registrado en el año 2016, debido al incremento en los volúmenes embarcados de productos tradicionales (10,8\%), principalmente de los sectores pesquero $(63,3 \%)$, petróleo y gas natural $(30,1 \%)$ y minero $(6,6 \%)$.

Por el lado de los productos no tradicionales destacaron los sectores pesquero $(69,6 \%)$, agropecuario (4,5\%), textil (5,1\%) y químico (3,5\%). (Informe Técnico INEI 2018) 
Exportación real, según país de destino: Diciembre 2017

(Millones de US dólares de 2007)

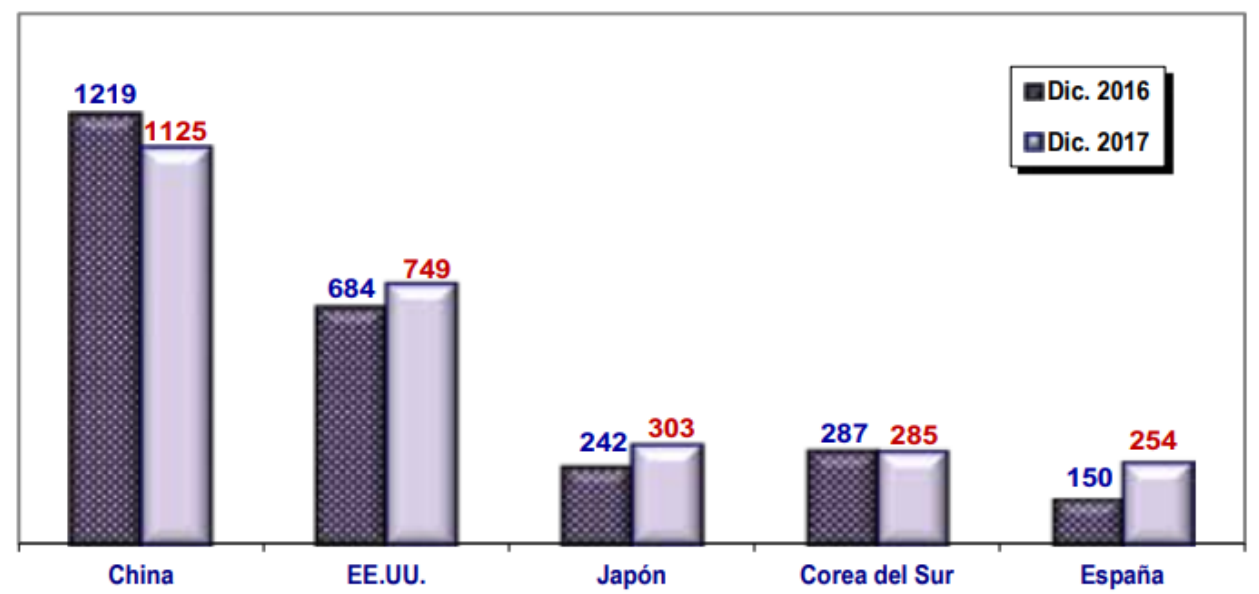

Figura 21. Principales países destino de exportaciones de Perú. Fuente: (Informe Técnico INEI 2018)

Actualmente el sector textil representa el $2.7 \%$ del total de las exportaciones no tradicionales peruanas, con una prospección de mercado con amplio margen de crecimiento que ofrece los productos y servicios de calidad que el país tiene para brindar al mercado internacional. (Promperú, 2018)

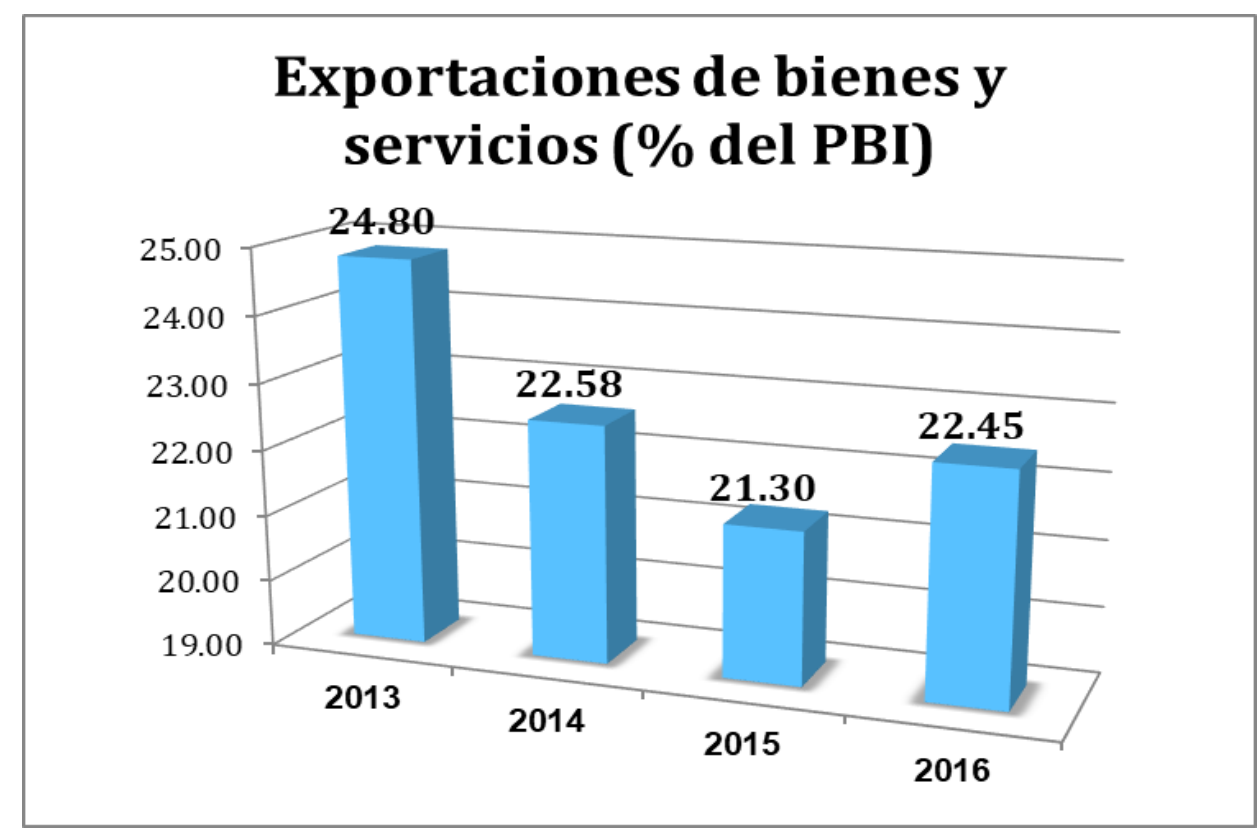

Figura 22. Porcentaje de Exportaciones de Bienes y Servicios respecto al PBI Perú. Elaboración propia con datos tomados de Indicadores de Desarrollo Mundial del Banco Mundial. 
Principales sectores productivos de la oferta exportadora peruana a Francia en el 2015

\begin{tabular}{|c|c|c|}
\hline \multirow{2}{*}{ SECTOR PRODUCTIVO } & \multicolumn{2}{|c|}{ VALOR FOB EXPORTADO 2016} \\
\cline { 2 - 3 } & MLLONES US\$ & $\%$ \\
\hline Agrícola/agropecuario & 101.3 & 37.2 \\
\hline Pesquero & 63.4 & 23.0 \\
\hline Petróleo y derivados & 50.1 & 20.7 \\
\hline Vestimenta & 15.3 & 6.2 \\
\hline Sidero-metalúrgico & 13.2 & 5.7 \\
\hline Otros sectores productivos & 20 & 7.2 \\
\hline
\end{tabular}

FUENTE: SUNAT http://www.sunat.gob.pe/

Figura 23. Exportaciones peruanas a Francia de Vestimenta 2016. Adaptado por SUNAT 2017

En la figura 23 se muestra los sectores productivos del abanico de productos que ofertamos y exportamos a Francia, de los cuales el $6.2 \%$ corresponde al rubro textil y genera 15.3 millones de dólares en el 2016.

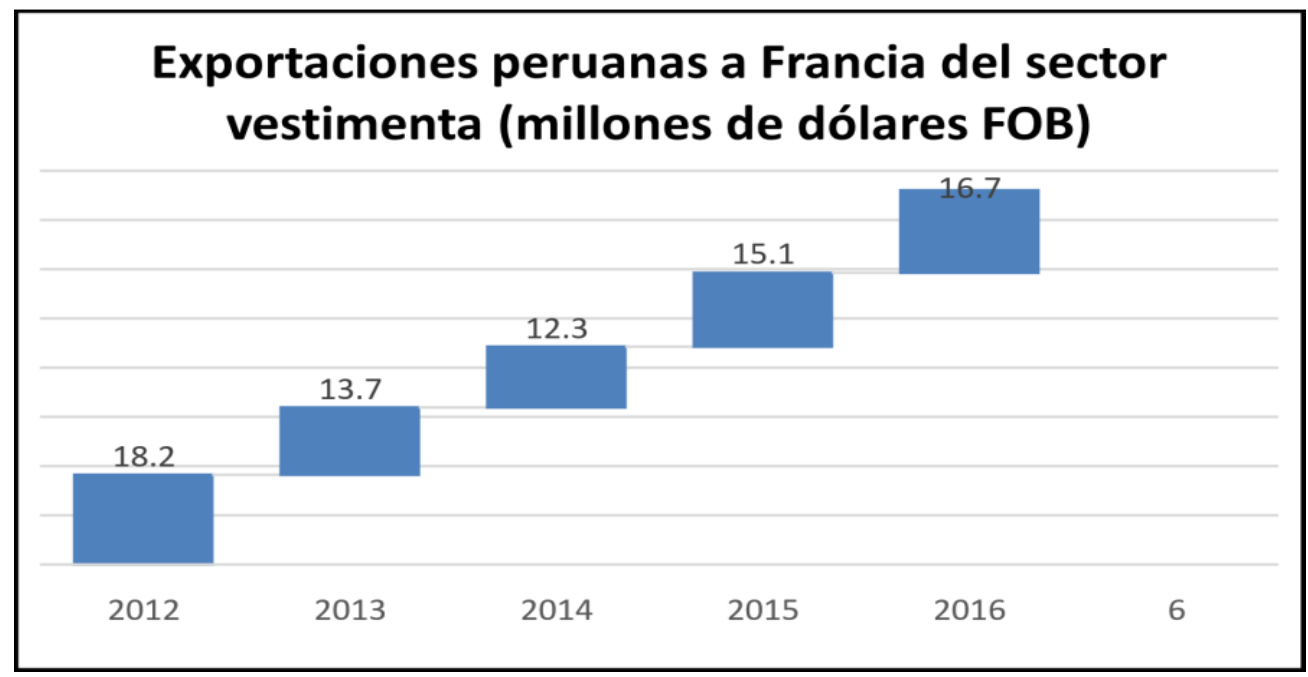

Figura 24. Exportaciones peruanas a Francia de Vestimenta 2012- 2016. Adaptado por SUNAT 2017 
En la figura 24, observamos que del 2012 al 2014 se redujeron las exportaciones debido a la crisis financiera de Europa, pero desde el 2015 hasta el 2016 esto ha ido en aumento y se espera siga el crecimiento continuo, ya que Europa poco a poco se está estabilizando de la crisis que le ocasionó una economía debilitada.

\subsubsection{Industria Textil Prendas de baño Perú}

La industria textil en el Perú ha avanzado a grandes pasos, todo esto se debe a pequeñas, medianas y grandes empresas que surgieron poco a poco y con el empuje y emprendimiento vieron los frutos ya sea en agrupaciones empresariales o en asociaciones con otras empresas en la ciudad capital. Tal es así, que hoy en día el emporio comercial de Gamarra en La Victoria es una concentración de grandes empresarios textiles, que no sólo proveen al mercado interno, sino, también externo. De este ejemplo tenemos a Kuna by Alpaca 111, Topy Top, Michelle Belau, etc.

Las fibras textiles para que puedan ser comercializadas pasan por un proceso de transformación hasta llegar al producto final y sobre todo si el producto va a ser exportado pasa por un control riguroso de calidad que cumpla con las especificaciones y normas de fabricación y comercialización.

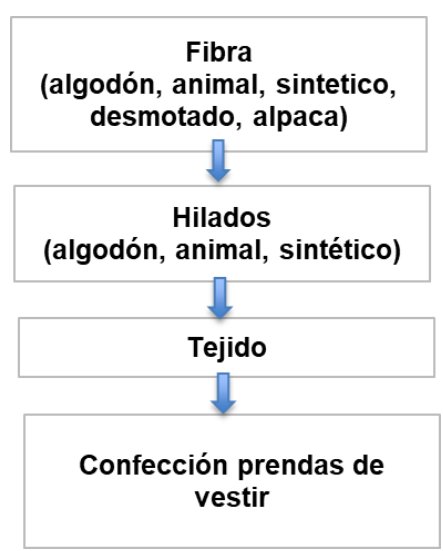

Figura 25. Flujo de la cadena productiva del sector textil. Adaptado por Reporte sectorial SNIIEES 2016. Fuente Reportes Financieros CETRUM 2010. 


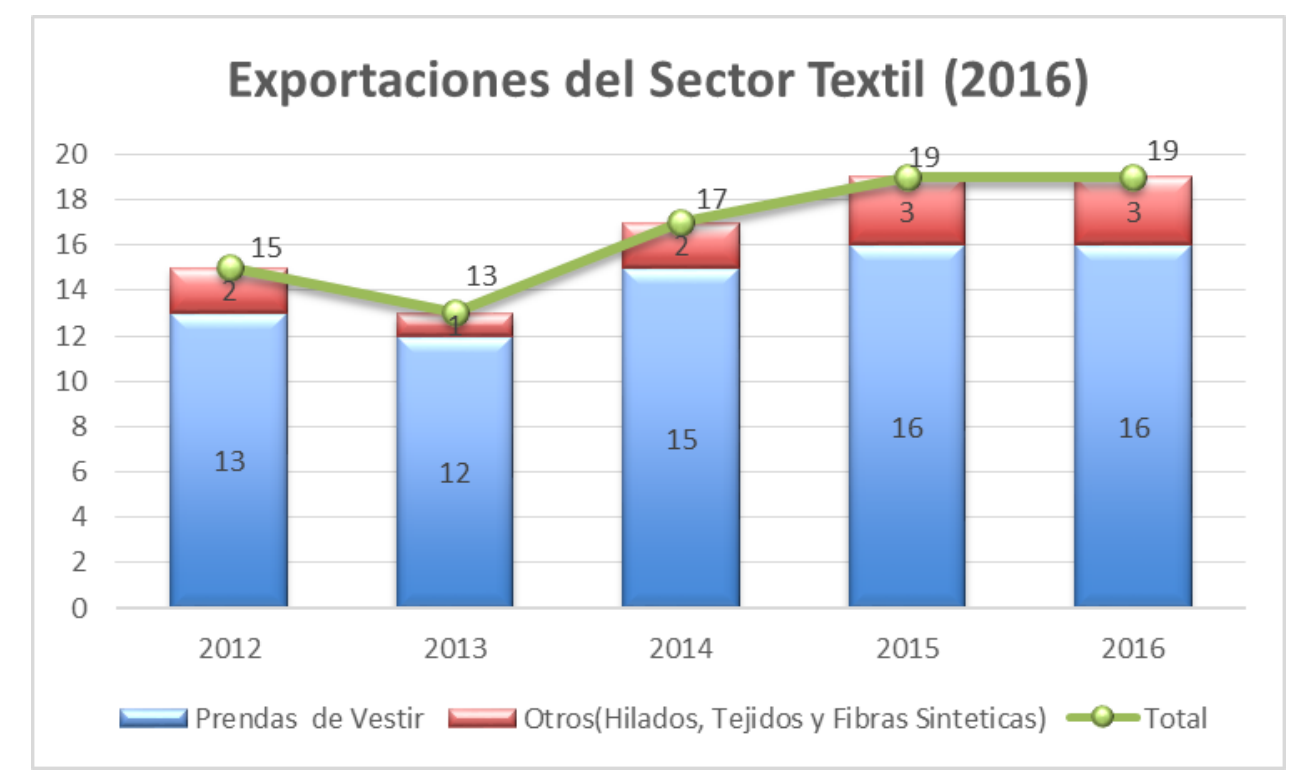

Figura 26. Exportaciones peruanas a Francia del sector textil del 2012 al 2016. Adaptado por SUNAT cifras en millones de dólares - PROMPERU (2017).

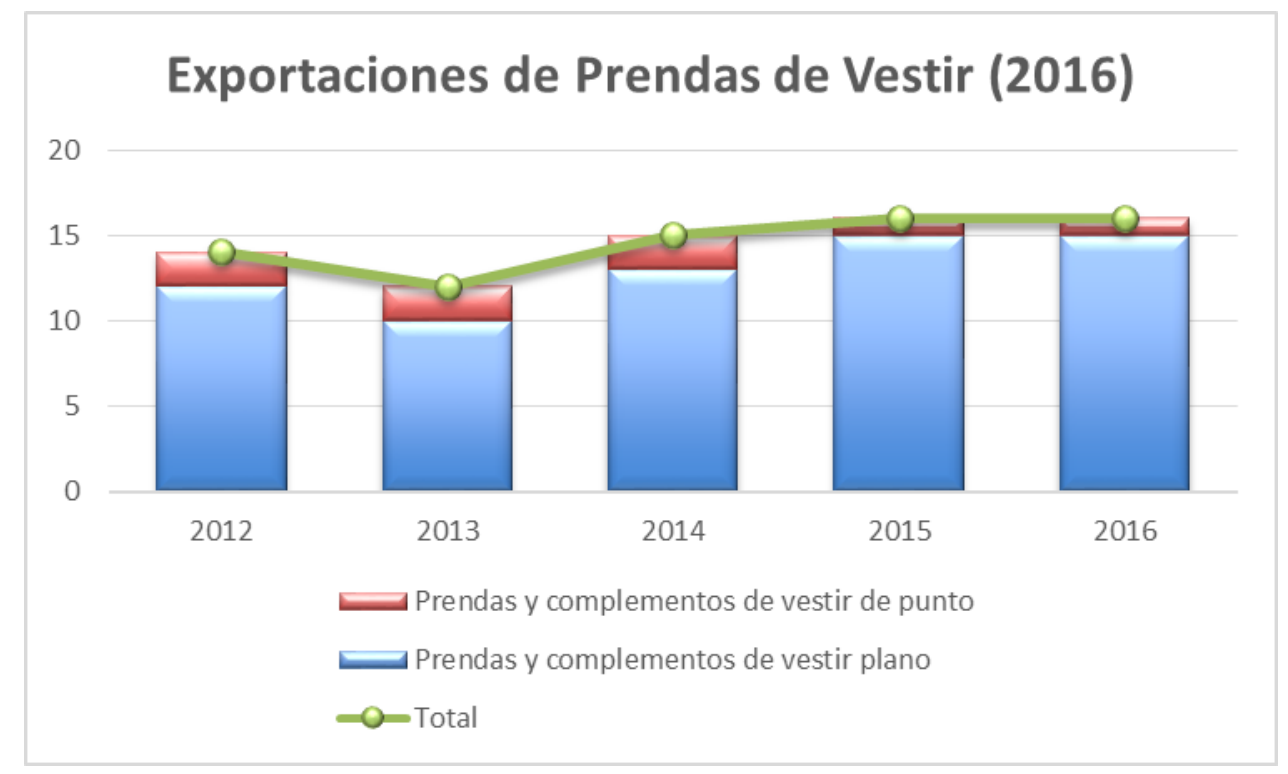

Figura 27. Exportaciones peruanas a Francia del sector textil del 2012 al 2016. Adaptado por SUNAT cifras en millones de dólares - PROMPERU (2017). 


\section{Principales partidas del sector vestimenta exportadas a Francia.}

\begin{tabular}{|c|c|c|c|c|}
\hline \multirow{2}{*}{$\begin{array}{l}\text { Código del } \\
\text { producto }\end{array}$} & \multirow[b]{2}{*}{ Descripción del producto } & \multicolumn{3}{|c|}{ Perú exporta hacia Francia } \\
\hline & & $\begin{array}{l}\text { Valor en } \\
2014\end{array}$ & $\begin{array}{l}\text { Valor en } \\
2015\end{array}$ & $\begin{array}{c}\text { Valor en } \\
2016\end{array}$ \\
\hline '6105 & $\begin{array}{l}\text { Camisas de punto, para hombres o niños (exc. camisones, "T- } \\
\text { shirts" y camisetas) }\end{array}$ & 6200 & 9023 & 9611 \\
\hline '6110 & $\begin{array}{l}\text { Suéteres "jerseys", "pullovers", cardiganes, chalecos y } \\
\text { artículos simil., de punto (exc. chalecos ... }\end{array}$ & 3108 & 2544 & 2478 \\
\hline '6109 & T-shirts y camisetas, de punto & 2321 & 2683 & 2055 \\
\hline '6106 & $\begin{array}{l}\text { Camisas, blusas y blusas camiseras, de punto, para mujeres } 0 \\
\text { niñas (exc. "T-shirts" y camisetas) }\end{array}$ & 414 & 473 & 703 \\
\hline '6104 & $\begin{array}{l}\text { Trajes sastre, conjuntos, chaquetas "sacos", vestidos, faldas, } \\
\text { faldas pantalón, pantalones ... }\end{array}$ & 424 & 244 & 418 \\
\hline '6111 & $\begin{array}{l}\text { Prendas y complementos "accesorios" de vestir, de punto, } \\
\text { para bebés (exc. gorras) }\end{array}$ & 230 & 153 & 230 \\
\hline '6102 & $\begin{array}{l}\text { Abrigos, chaquetones, capas, anoraks, cazadoras y artículos } \\
\text { simil., de punto, para mujeres ... }\end{array}$ & 126 & 178 & 182 \\
\hline '6117 & $\begin{array}{l}\text { Complementos "accesorios" de vestir confeccionados, de } \\
\text { punto; partes de prendas o de complementos ... }\end{array}$ & 272 & 168 & 109 \\
\hline '6112 & $\begin{array}{l}\text { Conjuntos de abrigo para entrenamiento o deporte } \\
\text { "chandales", monos "overoles" y conjuntos ... }\end{array}$ & 35 & 35 & 87 \\
\hline '6114 & $\begin{array}{l}\text { Prendas de vestir especiales, para usos específicos "p.ej., } \\
\text { profesional, deportivo, etc.", ... }\end{array}$ & 128 & 103 & 41 \\
\hline '6103 & $\begin{array}{l}\text { Trajes "ambos o ternos", conjuntos, chaquetas "sacos", } \\
\text { pantalones largos, pantalones con peto, ... }\end{array}$ & 14 & 15 & 29 \\
\hline '6101 & $\begin{array}{l}\text { Abrigos, chaquetones, capas, anoraks, cazadoras y artículos } \\
\text { simil., de punto, para hombres ... }\end{array}$ & 39 & 16 & 27 \\
\hline '6116 & Guantes, mitones y manoplas, de punto (exc. para bebés) & 51 & 50 & 26 \\
\hline '6115 & $\begin{array}{l}\text { Calzas, "panty-medias", leotardos, medias, calcetines y demás } \\
\text { artículos de calcetería, incl. ... }\end{array}$ & 21 & 24 & 14 \\
\hline '6108 & $\begin{array}{l}\text { Combinaciones, enaguas, bragas "bombachas, calzones", incl. } \\
\text { las que no llegan hasta la cintura, ... }\end{array}$ & 14 & 2 & 10 \\
\hline '6107 & $\begin{array}{l}\text { Calzoncillos, incl. los largos y los "slips", camisones, pijamas, } \\
\text { albornoces de baño, batas ... }\end{array}$ & 2 & 0 & 3 \\
\hline '6113 & $\begin{array}{l}\text { Prendas de vestir confeccionadas con tejidos de punto, } \\
\text { cauchutados o impregnados, recubiertos ... }\end{array}$ & 0 & 0 & 0 \\
\hline
\end{tabular}




\begin{tabular}{|c|c|c|c|c|}
\hline \multirow{2}{*}{$\begin{array}{l}\text { Código del } \\
\text { producto }\end{array}$} & \multirow[b]{2}{*}{ Descripción del producto } & \multicolumn{3}{|c|}{ Perú exporta hacia Francia } \\
\hline & & $\begin{array}{l}\text { Valor en } \\
2014\end{array}$ & $\begin{array}{l}\text { Valor en } \\
2015\end{array}$ & $\begin{array}{l}\text { Valor en } \\
2016\end{array}$ \\
\hline '6204 & $\begin{array}{l}\text { Trajes sastre, conjuntos, chaquetas "sacos", vestidos, faldas, } \\
\text { faldas pantalón, pantalones ... }\end{array}$ & 488 & 301 & 163 \\
\hline '6205 & $\begin{array}{l}\text { Camisas para hombres o niños (exc. de punto, así como } \\
\text { camisones y camisetas) }\end{array}$ & 223 & 16 & 62 \\
\hline '6203 & $\begin{array}{l}\text { Trajes "ambos o ternos", conjuntos, chaquetas "sacos", } \\
\text { pantalones largos, pantalones con peto, ... }\end{array}$ & 303 & 3 & 51 \\
\hline '6206 & $\begin{array}{l}\text { Camisas, blusas y blusas camiseras, para mujeres o niñas (exc. } \\
\text { de punto y camisetas) }\end{array}$ & 261 & 235 & 49 \\
\hline '6214 & $\begin{array}{l}\text { Chales, pañuelos de cuello, pasamontañas, bufandas, } \\
\text { mantillas, velos y artículos simil. (exc. ... }\end{array}$ & 91 & 29 & 29 \\
\hline '6202 & $\begin{array}{l}\text { Abrigos, chaquetones, capas, anoraks, cazadoras y artículos } \\
\text { simil., para mujeres o niñas (exc.... }\end{array}$ & 67 & 16 & 29 \\
\hline '6212 & $\begin{array}{l}\text { Sostenes "corpiños", fajas, corsés, tirantes "tiradores", ligas y } \\
\text { artículos simil. y sus partes, ... }\end{array}$ & 0 & 76 & 5 \\
\hline '6211 & $\begin{array}{l}\text { Conjuntos de abrigo para entrenamiento o deporte } \\
\text { "chandales", monos "overoles y conjuntos de ... }\end{array}$ & 77 & 53 & 5 \\
\hline '6209 & $\begin{array}{l}\text { Prendas y complementos "accesorios", de vestir, de todo tipo } \\
\text { de materia textil, para bebés ... }\end{array}$ & 0 & 0 & 3 \\
\hline '6215 & Corbatas y lazos simil., de materia textil (exc. de punto) & 0 & 0 & 0 \\
\hline '6217 & $\begin{array}{l}\text { Complementos "accesorios" de vestir confeccionados, así } \\
\text { como partes de prendas o de complementos ... }\end{array}$ & 4 & 1 & 0 \\
\hline '6207 & $\begin{array}{l}\text { Camisetas interiores, calzoncillos, incl. los largos y los "slips", } \\
\text { camisones, pijamas, albornoces ... }\end{array}$ & 4 & 0 & 0 \\
\hline '6213 & $\begin{array}{l}\text { Pañuelos de bolsillo, cuyos lados sean de longitud }<=60 \mathrm{~cm} \\
\text { (exc. de punto) }\end{array}$ & 0 & 0 & 0 \\
\hline '6216 & $\begin{array}{l}\text { Guantes, mitones y manoplas, de todo tipo de materia textil } \\
\text { (exc. de punto, así como guantes, ... }\end{array}$ & 5 & 0 & 0 \\
\hline '6201 & $\begin{array}{l}\text { Abrigos, chaquetones, capas, anoraks, cazadoras y artículos } \\
\text { simil., para hombres o niños (exc. ... }\end{array}$ & 17 & 22 & 0 \\
\hline '6208 & $\begin{array}{l}\text { Camisetas interiores, combinaciones, enaguas, bragas } \\
\text { "bombachas, calzones", incl. las que no ... }\end{array}$ & 0 & 1 & 0 \\
\hline '6210 & $\begin{array}{l}\text { Prendas de vestir confeccionadas con fieltro y tela sin tejer, } \\
\text { incl. impregnadas, recubiertas, ... }\end{array}$ & 2 & 15 & 0 \\
\hline
\end{tabular}




\begin{tabular}{|c|c|c|c|c|}
\hline \multirow{2}{*}{$\begin{array}{l}\text { Código } \\
\text { del } \\
\text { producto }\end{array}$} & \multirow[b]{2}{*}{ Descripción del producto } & \multicolumn{3}{|c|}{ Perú exporta hacia Francia } \\
\hline & & $\begin{array}{l}\text { Valor en } \\
2014\end{array}$ & $\begin{array}{l}\text { Valor en } \\
2015\end{array}$ & $\begin{array}{l}\text { Valor en } \\
2016\end{array}$ \\
\hline '6301 & $\begin{array}{l}\text { Mantas de todo tipo de materia textil (exc. manteles y } \\
\text { colchas, así como artículos de cama ... }\end{array}$ & 154 & 200 & 173 \\
\hline '6307 & $\begin{array}{l}\text { Artículos de materia textil, confeccionados, incl. los patrones } \\
\text { para prendas de vestir, n.c.o.p. }\end{array}$ & 4 & 11 & 13 \\
\hline '6305 & $\begin{array}{l}\text { Sacos "bolsas" y talegas, para envasar, de todo tipo de } \\
\text { materia textil }\end{array}$ & 0 & 0 & 5 \\
\hline '6302 & $\begin{array}{l}\text { Ropa de cama, de mesa, de tocador o de cocina, de todo tipo } \\
\text { de materia textil (exc. bayetas, ... }\end{array}$ & 2 & 0 & 4 \\
\hline '6303 & $\begin{array}{l}\text { Visillos y cortinas; guardamalletas y ropadiés de cama, de todo } \\
\text { tipo de materia textil (exc.... }\end{array}$ & 0 & 0 & 1 \\
\hline '6310 & $\begin{array}{l}\text { Trapos de todo tipo de materia textil, así como cordeles, } \\
\text { cuerdas y cordajes, de materia textil, ... }\end{array}$ & 0 & 0 & 0 \\
\hline '6304 & $\begin{array}{l}\text { Artículos de moblaje de todo tipo de materia textil (exc. } \\
\text { mantas, ropa de cama, de mesa, de ... }\end{array}$ & 0 & 0 & 0 \\
\hline
\end{tabular}

\begin{tabular}{|c|c|c|c|c|}
\hline \multirow{2}{*}{$\begin{array}{l}\text { Código } \\
\text { del } \\
\text { producto }\end{array}$} & \multirow[b]{2}{*}{ Descripción del producto } & \multicolumn{3}{|c|}{ Perú exporta hacia Francia } \\
\hline & & $\begin{array}{l}\text { Valor en } \\
2014\end{array}$ & $\begin{array}{l}\text { Valor en } \\
2015\end{array}$ & $\begin{array}{l}\text { Valor en } \\
2016\end{array}$ \\
\hline '6309 & $\begin{array}{l}\text { Artículos de prendería consistentes en prendas y } \\
\text { complementos "accesorios" de vestir, mantas, ... }\end{array}$ & 0 & 0 & 0 \\
\hline '6306 & $\begin{array}{l}\text { Toldos de cualquier clase, tiendas "carpas", velas para } \\
\text { embarcaciones, deslizadores o vehículos ... }\end{array}$ & 0 & 0 & 0 \\
\hline '6308 & $\begin{array}{l}\text { Juegos constituidos por piezas de tejido e hilados, incl. con } \\
\text { accesorios, para la confección ... }\end{array}$ & 0 & 0 & 0 \\
\hline
\end{tabular}

Tabla 3. Partidas principales del sector textil, exportadas a Francia del 2014 al 2016. Adaptado por TradeMap. 


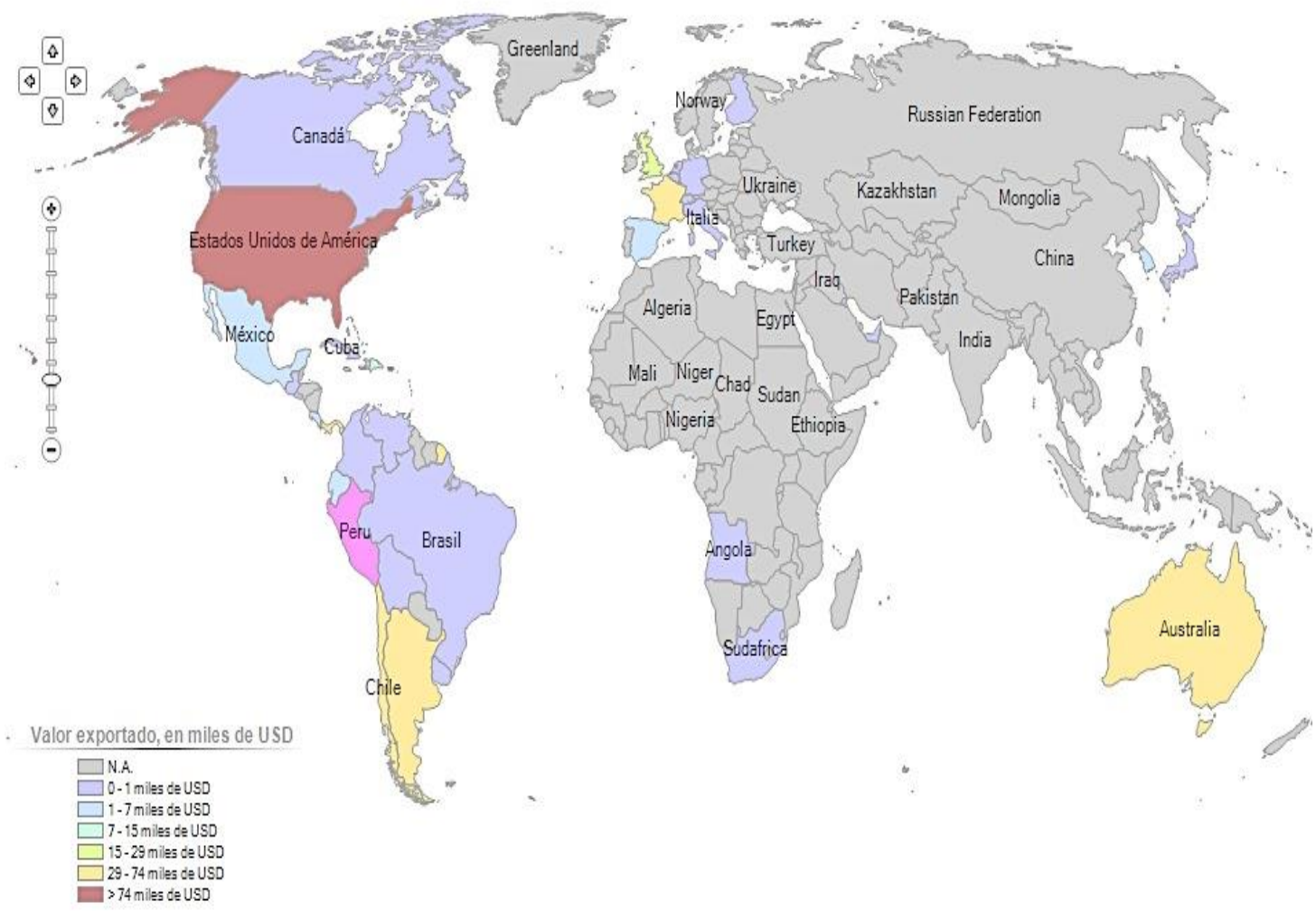

Figura 28. Mapa de mercados importadores de un producto exportado por Perú en el 2016 Partida Arancelaria: 611241. Fuente: Trademap (2018).

\begin{tabular}{|c|c|c|c|c|c|c|c|c|c|c|c|}
\hline \multirow[b]{2}{*}{$\begin{array}{l}\text { Código del } \\
\text { producto }\end{array}$} & \multirow[b]{2}{*}{ Descripción del producto } & \multicolumn{5}{|c|}{ Perú exporta hacia Francia } & \multicolumn{5}{|c|}{ Perú exporta hacia el mundo } \\
\hline & & $\begin{array}{c}\text { Valor } \\
\text { en } \\
2012\end{array}$ & $\begin{array}{c}\text { Valor } \\
\text { en } \\
2013\end{array}$ & $\begin{array}{c}\text { Valor } \\
\text { en } \\
2014\end{array}$ & $\begin{array}{c}\text { Valor } \\
\text { en } \\
2015\end{array}$ & $\begin{array}{c}\text { Valor } \\
\text { en } \\
2016\end{array}$ & $\begin{array}{l}\text { Valor en } \\
2012\end{array}$ & $\begin{array}{c}\text { Valor } \\
\text { en } \\
2013\end{array}$ & $\begin{array}{c}\text { Valor } \\
\text { en } \\
2014\end{array}$ & $\begin{array}{c}\text { Valor } \\
\text { en } \\
2015\end{array}$ & $\begin{array}{c}\text { Valor } \\
\text { en } \\
2016\end{array}$ \\
\hline 6112410000 & $\begin{array}{l}\text { Bañadores de } \\
\text { punto, de fibras } \\
\text { sintéticas, para } \\
\text { mujeres o niñas }\end{array}$ & 0 & 0 & 35 & 35 & 39 & 3.152 & 950 & 489 & 387 & 425 \\
\hline
\end{tabular}

Unidad: Dólar Americano miles

Tabla 4. Exportaciones peruanas hacia Francia y hacia el mundo del 2012 - 2016. Fuente: Trademap. 


\begin{tabular}{|c|c|c|c|c|c|}
\hline Descripción Partida Aduanera & $\begin{array}{c}\text { Total } \\
\text { registros }\end{array}$ & $\begin{array}{c}\text { Total US\$ } \\
\text { FOB }\end{array}$ & $\%$ & Total U & US\$ / U \\
\hline $\begin{array}{c}\text { 6112410000 TRAJES DE } \\
\text { BAÑO (DE UNA O DOS } \\
\text { PIEZAS), DE PUNTO, DE } \\
\text { FIBRAS SINTETICAS, }\end{array}$ & 26 & 109,117 & 100.00 & 6,714 & 16.252 \\
\hline
\end{tabular}

Tabla 5. Exportaciones Peruanas hacia Francia del 2013 - 2016. Fuente: Trademap.

\begin{tabular}{|c|c|c|c|c|c|}
\hline Exportador & $\begin{array}{c}\text { Total } \\
\text { registros }\end{array}$ & $\begin{array}{c}\text { Total US\$ } \\
\text { FOB }\end{array}$ & $\%$ & Total U & US\$ / U \\
\hline $\begin{array}{c}\text { GRUPO SANTA LUCIA } \\
\text { SOCIEDAD ANONIMA } \\
\text { CERRA }\end{array}$ & 13 & 72,819 & $66.73 \%$ & 5,672 & 12.838 \\
\hline APPLAUZI S A & 13 & 36,299 & $33.27 \%$ & 1,042 & 34.835 \\
\hline Total & $\mathbf{2 6}$ & $\mathbf{1 0 9 , 1 1 7}$ & $\mathbf{1 0 0 . 0 0 \%}$ & $\mathbf{6 , 7 1 4}$ & $\mathbf{1 6 . 2 5 2}$ \\
\hline
\end{tabular}

Tabla 6. Exportadores peruanos hacia Francia del 2013 - 2016. Fuente: Trademap.

\begin{tabular}{|c|c|c|c|c|c|}
\hline Importador & $\begin{array}{c}\text { Total } \\
\text { registros }\end{array}$ & $\begin{array}{c}\text { Total US\$ } \\
\text { FOB }\end{array}$ & $\%$ & Total U & US\$ / U \\
\hline LUZ COLLECTION & 11 & 45,732 & $41.91 \%$ & 4,206 & 10.873 \\
\hline GIRAPHES COMMERCE & 2 & 27,087 & $24.82 \%$ & 1,466 & 18.476 \\
\hline BRAZILIANBIKINI - & & & & & \\
JEAN MARC GUETERE & 6 & 22,486 & $20.61 \%$ & 518 & 43.409 \\
\hline SARL BEGA & 7 & 13,813 & $12.66 \%$ & 524 & 26.360 \\
\hline Total & $\mathbf{2 6}$ & $\mathbf{1 0 9 , 1 1 7}$ & $\mathbf{1 0 0 . 0 0 \%}$ & $\mathbf{6 , 7 1 4}$ & $\mathbf{1 6 . 2 5 2}$ \\
\hline
\end{tabular}

Tabla 7. Importadores Franceses que realizaron operaciones comerciales con exportadores Peruanos 2013 - 2016. Fuente: Trademap. 


\subsubsection{Destinos textiles peruanos}

Las prendas textiles peruanas son muy solicitadas a nivel mundial por la calidad, variedad de diseños e innovación con las que son creadas para los sectores más exigentes a nivel mundial. Los productos peruanos compiten con total destreza con Colombia, Brasil, China, Ecuador, entre otros.

PRINCIPALES EMPRESAS

EXPORTADORAS
PRINCIPALES MERCADOS

\begin{tabular}{|c|c|c|c|c|c|c|}
\hline Empresa & $\begin{array}{l}\% \operatorname{Var} \\
16-15\end{array}$ & $\begin{array}{l}\% \mathrm{~Pa} \\
\mathrm{rt} . \\
16\end{array}$ & Mercado & $\begin{array}{l}\mathrm{r} \\
16- \\
15\end{array}$ & $\begin{array}{l}\% \text { Par } \\
\text { t. } \\
16\end{array}$ & $\begin{array}{l}\text { FOB-16 } \\
\text { (miles } \\
\text { US\$) }\end{array}$ \\
\hline $\begin{array}{l}\text { SAN LORENZO } \\
\text { CORPORATION }\end{array}$ & $9 \%$ & $28 \%$ & $\begin{array}{l}\text { Estados } \\
\text { Unidos }\end{array}$ & $-3 \%$ & $34 \%$ & 145.90 \\
\hline $\begin{array}{l}\text { SOCIEDAD ... } \\
\text { APPLAUZI S A }\end{array}$ & $20 \%$ & $25 \%$ & Chile & $\begin{array}{l}263 \\
\%\end{array}$ & $14 \%$ & 60.69 \\
\hline $\begin{array}{l}\text { CICCIA } \\
\text { PIEROBON } \\
\text { RENZO } \\
\text { DOMENICO }\end{array}$ & -- & $9 \%$ & $\begin{array}{l}\text { Francia } \\
\text { Panamá }\end{array}$ & $\begin{array}{l}11 \% \\
210 \\
\%\end{array}$ & $\begin{array}{l}9 \% \\
9 \%\end{array}$ & 39.28 \\
\hline $\begin{array}{l}\text { TOQUE D'SOL } \\
\text { S.R.L. }\end{array}$ & $53 \%$ & $8 \%$ & $\begin{array}{l}\text { Argentina } \\
\text { Australia }\end{array}$ & $53 \%$ & $\begin{array}{l}9 \% \\
8 \%\end{array}$ & $\begin{array}{l}36.52 \\
35.34\end{array}$ \\
\hline TAMI'S E.I.R.L. & -- & $8 \%$ & Reino Unido & - & $4 \%$ & 18.17 \\
\hline $\begin{array}{l}\text { GRUPO SANTA } \\
\text { LUCIA } \\
\text { SOCIEDAD }\end{array}$ & $9 \%$ & $6 \%$ & Curazao & $\begin{array}{l}380 \\
\%\end{array}$ & $3 \%$ & 10.70 \\
\hline $\begin{array}{l}\text { ANONIM... } \\
\text { CONSORCIO }\end{array}$ & 270558 & & Líbano & - & $2 \%$ & 10.25 \\
\hline TEXTIL & $\%$ & $4 \%$ & & & & \\
\hline
\end{tabular}




\begin{tabular}{|c|c|c|}
\hline $\begin{array}{l}\text { EXPORTADOR } \\
\text { SAC }\end{array}$ & & \\
\hline CM TEX S.A.C. & -- & $4 \%$ \\
\hline $\begin{array}{l}\text { QUALIMODA } \\
\text { S.A.C. }\end{array}$ & $-74 \%$ & $2 \%$ \\
\hline $\begin{array}{l}\text { Otras Empresas } \\
(21)\end{array}$ & -- & $3 \%$ \\
\hline
\end{tabular}

Otros Paises

Fuente: SUNAT

Fuente: SUNAT

Figura 29. Principales Importadores y Exportadores para el producto bañadores de punto, de fibras sintéticas para mujeres y niñas exportado por Perú. Fuente: Siicex (2018)

Precios FOB referenciales en kilogramos (US\$ / Kgr)

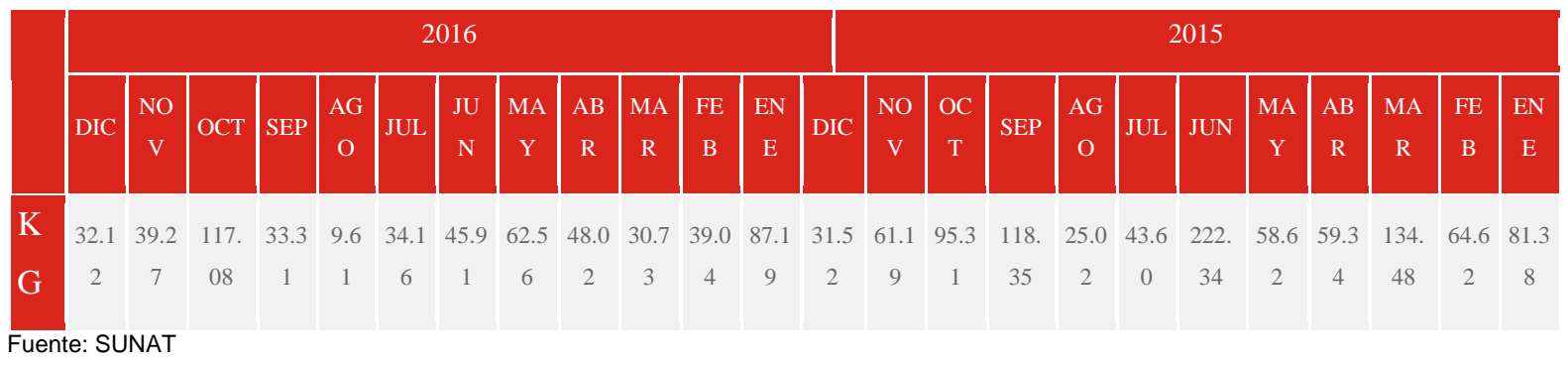

Figura 30. Principales Importadores y Exportadores para el producto bañadores de punto, de fibras sintéticas para mujeres y niñas exportado por Perú. Fuente: Siicex (2018) 


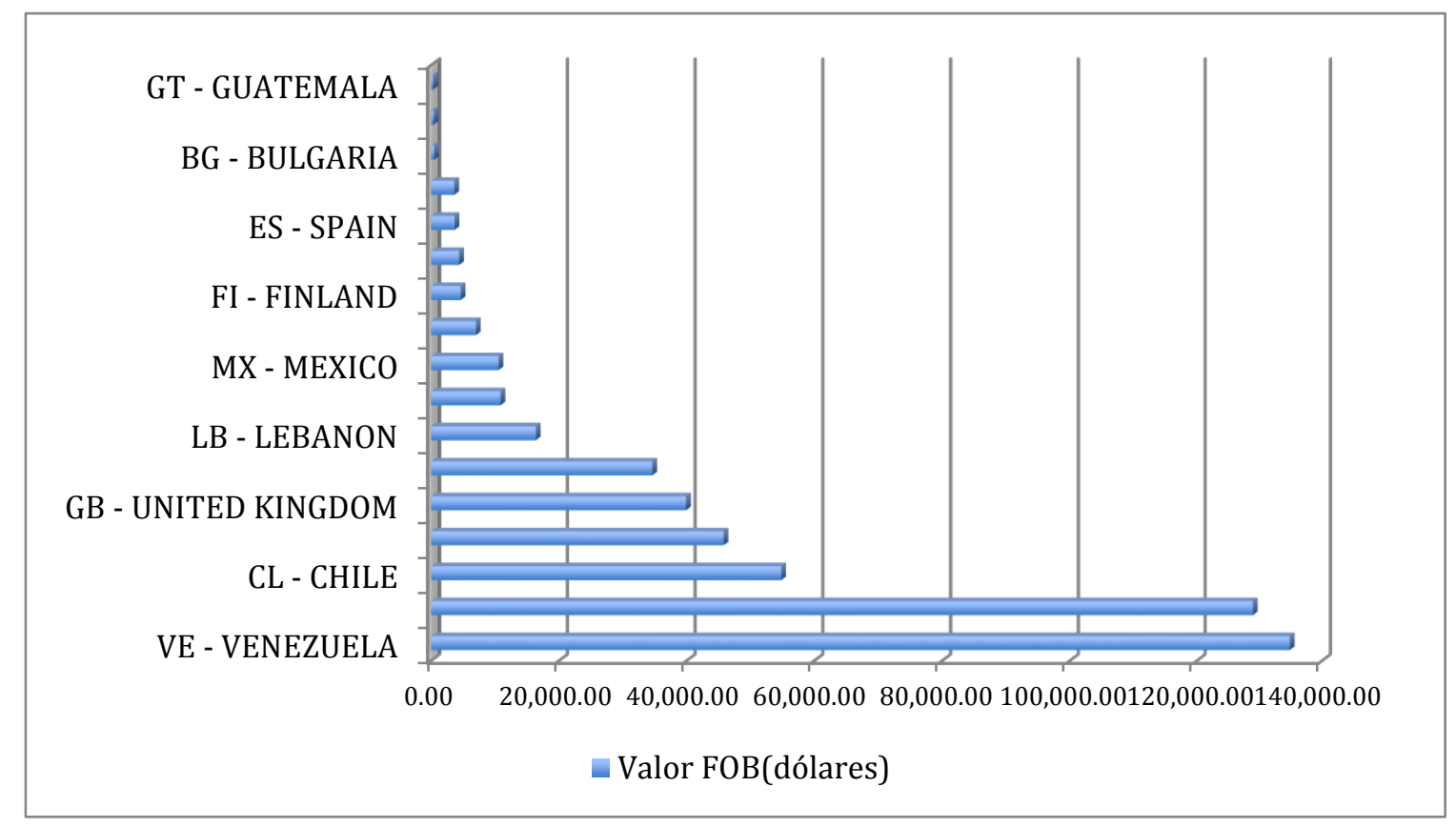

Figura 31. Exportaciones Peruanas del 2014 Partida $N^{\circ} 6112410000$ Trajes de baño de fibra sintética para damas y niñas. Fuente: Elaboración propia con información Extraída de Aduanet. La figura 31 muestra que Venezuela y chile eran los principales importadores de prendas de baño.

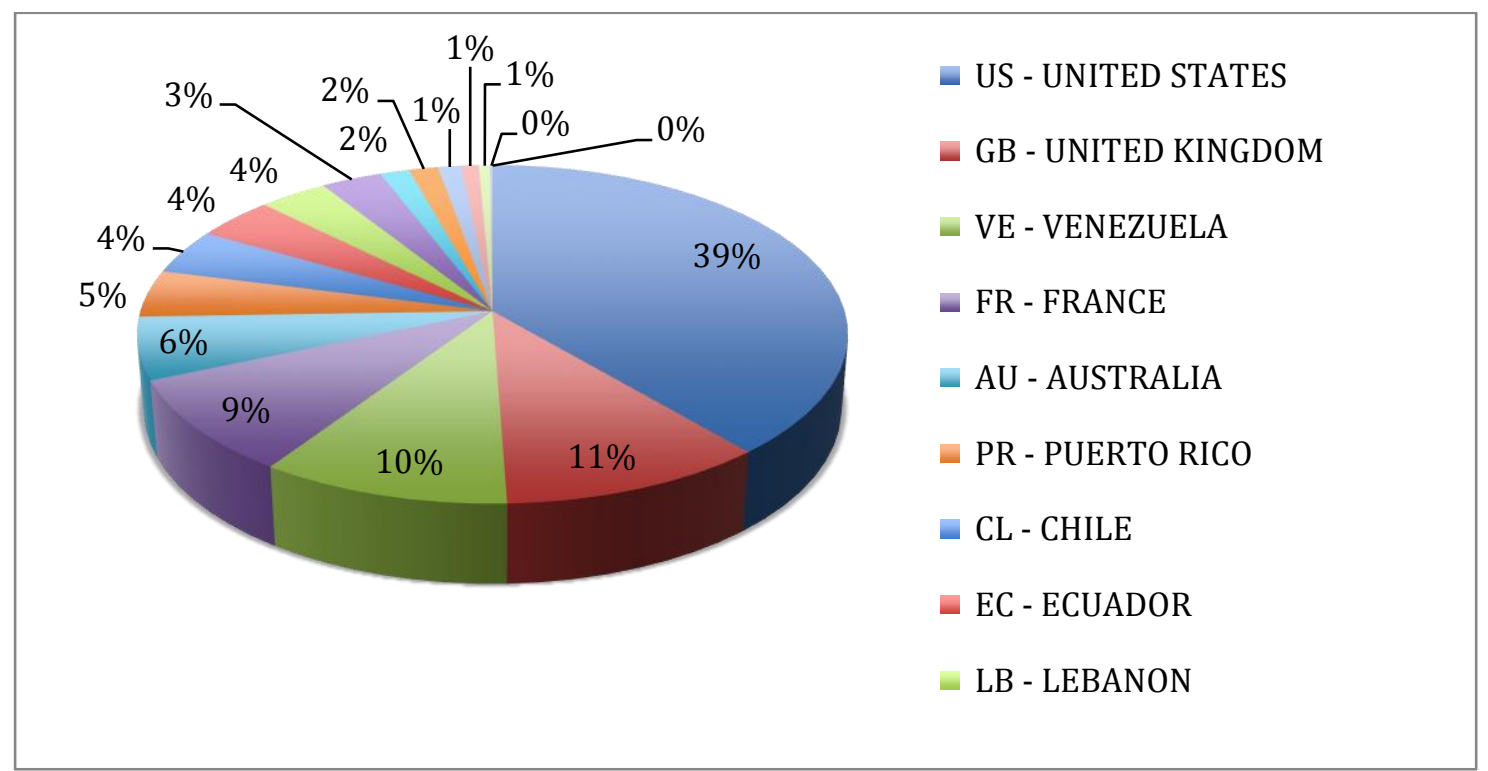

Figura 32. Exportaciones Peruanas del 2015 Partida $N^{\circ} 6112410000$ Trajes de baño de fibra sintética para damas y niñas. Fuente: Elaboración propia con información Extraída de Aduanet. 
Para el año 2015, el principal importador de prendas de baño peruanas fue Estados Unidos.

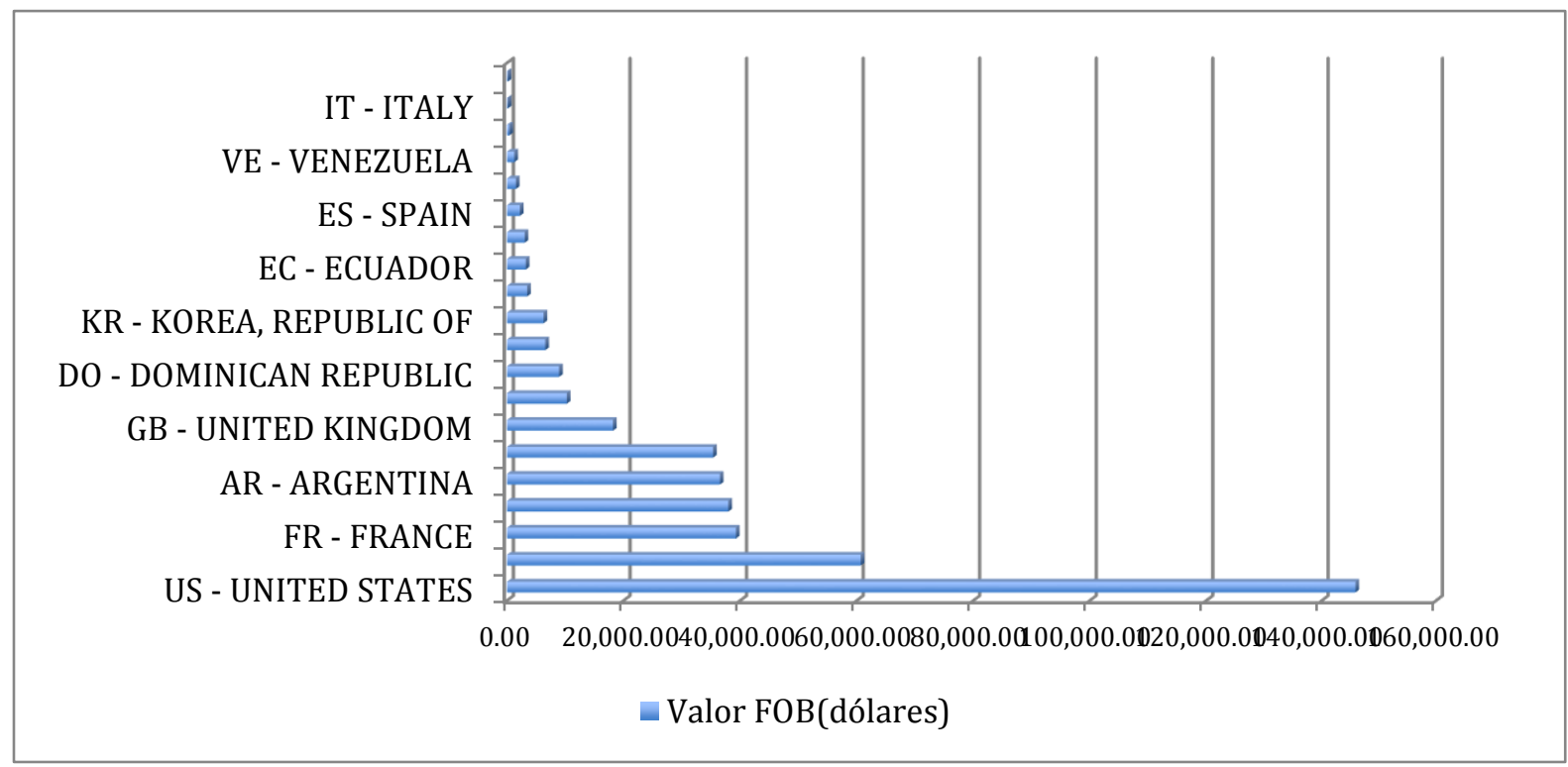

Figura 33. Exportaciones Peruanas del 2016 Partida $N^{a} 6112410000$ Trajes de baño de fibra sintética para damas y niñas. Fuente: Elaboración propia con información Extraída de Aduanet. Por segundo año consecutivo Estados Unidos es el principal importador de prendas de baño peruanas seguido por Francia en el 2016.

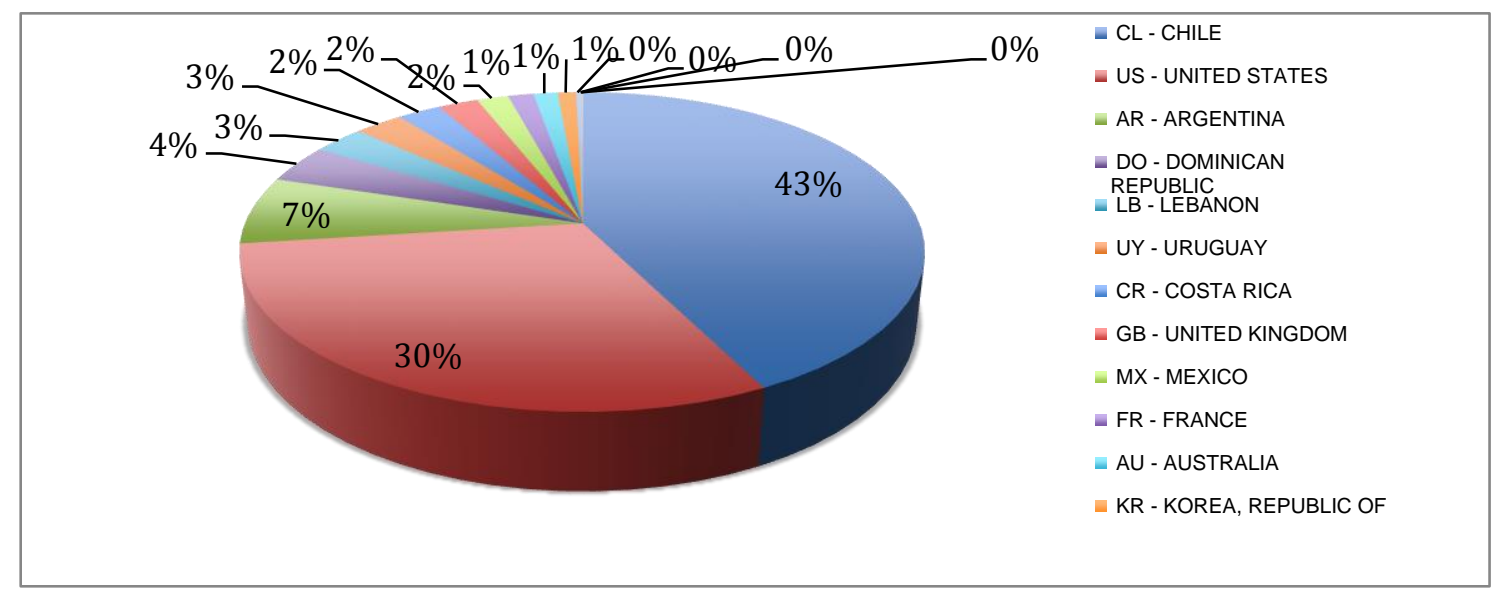

Figura 34. Exportaciones Peruanas del 2017 Partida N ${ }^{\mathrm{a}} 6112410000$ Trajes de baño de fibra sintética para damas y niñas. Fuente: Elaboración propia con información Extraída de Aduanet. 
En el 2017, Chile se convirtió en el principal importador de bañadores peruanos superando a Estados Unidos.

\subsubsection{Disposiciones del comercio Internacional}

\subsubsection{Comercio internacional}

El comercio internacional se ha venido desarrollando de manera progresiva a la par con el avance de la tecnología, con esto, se van acortando las fronteras a través de los diferentes mecanismos de procesamiento de datos financieros, bancarios, económicos, aduaneros, logísticos, etc. en línea o de manera virtual, se hace más dinámico y competitivo el comercio entre países. No obstante, son de gran ayuda los acuerdos comerciales con diferentes estados de diversos continentes de manera que resuelven la realización de sus operaciones de una forma armónica y bajo ciertos lineamientos o regulaciones que ayudan a preservan el medio ambiente, salud y seguridad de la población.

Las micro, pequeñas y medianas empresas conocidas como pymes pertenecen a un sector importante de la economía de los países en desarrollo como es el caso peruano ya que la producción de los mismos constituyen parte relevante del PBI (López y Tan, 2010), y de esta manera colaboran al auge de la productividad, aportan al comercio internacional y son una fuente muy rica de iniciativas y emprendimiento empresarial (Saavedra García, 2012) y promueven la generación de empleos directos e indirectos. 


\subsubsection{El Perú y la Organización Mundial del Comercio - OMC}

\subsubsection{Definición}

El Perú fue parte contratante del GATT (Acuerdo General de Comercio y Aranceles) de 1947 desde el 7 de octubre de 1951 y es miembro fundador de la OMC desde el $1^{\circ}$ de enero de 1995.

Los Acuerdos de la OMC fueron incorporados a la legislación nacional mediante Resolución Legislativa $\mathrm{N}^{\circ} 26407$ “Aprueban Acuerdo por el que se establece la Organización Mundial del Comercio y los Acuerdos Comerciales Multilaterales contenidos en el Acta Final de la Ronda Uruguay" de fecha 16 de diciembre de 1994.

La OMC es un elemento fundamental en el marco de la política comercial del Perú y de negociaciones comerciales internacionales. Todas las negociaciones comerciales regionales y bilaterales se basan en la normativa OMC y tienen que guardar consistencia con ella. Además, por transparencia, todos los acuerdos regionales y bilaterales deben ser examinados por los miembros de la OMC.

El Acuerdo de la OMC sobre los textiles y vestidos (ATV) entró en vigor en 1995 y terminó en el 2005; abarcó en un principio a todo lo relacionado con los hilados, tejidos, artículos textiles confeccionados y prendas de vestir, comenzó con una idea de hacerse un programa de integración progresivo de textiles y vestidos en las normas del GATT de 1994 para realizar un proceso de liberación y así poder incrementar progresivamente los contingentes existentes, debiendo aumentar anualmente los coeficientes de crecimiento. 
El proceso de integración que se detalla en el artículo 2 de la ATV, anticipa la manera que todos los miembros integraran los productos enumerados en el anexo de las normas del GATT a lo largo de un periodo de 10 años, lo cual se ejecutó en 4 etapas.

El objetivo de la negociación ha sido lograr que el sector de los textiles y el vestido en el que una gran parte del comercio está sujeta actualmente a contingentes bilaterales negociados en el marco del Acuerdo Multifibras (AMF), se integre finalmente en el GATT sobre la base de normas y disciplinas del GATT reforzada.

Sin embargo, la finalización del ATV, se dio debido a que al ser un acuerdo transitorio que duro 10 años, tampoco se pudo cumplir con el objetivo del acuerdo, que era, el fortalecer paulatinamente las industrias nacionales durante este periodo, beneficiando solo algunos países como China y Vietnam.

\subsubsection{El Acuerdo de Facilitación del Comercio y su efecto en la industria textil}

El Acuerdo de Facilitación del Comercio de la OMC entró en vigor en febrero del 2017, es el primer acuerdo multilateral concluido en los 21 años de existencia de la Organización Mundial del Comercio. Al recibir cuatro nuevas ratificaciones, la $\mathrm{OMC}$ ha obtenido la aceptación del Acuerdo sobre Facilitación del Comercio (AFC) por dos tercios de los 164 Miembros de la Organización, mínimo requerido para la entrada en vigor del AFC. 
Los acuerdos han impulsado reformas en procedimientos aduaneros que disminuyen tiempos y costos facilitando el intercambio comercial internacional.

En un estudio de 2015 realizado por los economistas de la OMC, se prevé que la plena aplicación del AFC reducirá los costos del comercio de los Miembros en un $14,3 \%$, en promedio, y serán los países en desarrollo los que más se beneficien.

Según ADEX, en la exportación la primera barrera son los aranceles, la segunda son las normas de origen y la tercera son los procedimientos aduaneros.

El país buscará formular resoluciones específicas para el tratamiento de mercancías de manera personalizada, y poder lograr aranceles propios de cada producto y familia de producto en lugar de categorías extensas que terminan desfavoreciendo a los pequeños exportadores, como es el caso de la industria textil donde los aranceles se discriminan en 5 grandes grupos que cobijan las más de 274 líneas de actividad.

\subsubsection{Plan Estratégico Nacional Exportador - PENX 2025}

Mediante el Plan Estratégico Nacional Exportador (PENX 2015 - 2025) el Estado Peruano busca impulsar el crecimiento de las operaciones de intercambio comercial entre Perú y los países del mundo. 
Este plan nacional consta de 4 grandes y relevantes pilares estratégicos que se detallan a continuación:

Pilar 1: Internacionalización de la empresa y diversificación de mercados.

Las empresas de los países emergentes necesitan el apoyo del Estado para realizar de manera competitiva $y$ formal un exitoso Plan de Internacionalización con acceso a mercados ampliados como resultado de acuerdos y convenios suscritos con el Perú. Sólo si las empresas se esfuerzan en invertir y desarrollar productos y servicios de calidad y competitivos lograrán la ansiada internacionalización.

Pilar 2: Oferta exportable diversificada, competitiva y sostenible.

Para crear una oferta exportable se deben establecer iniciativas, instrumentos y mecanismos orientados a una política de desarrollo productivo para generar el fortalecimiento de la diversificación de la oferta exportable competitiva y sostenible. Las empresas deben desarrollar planes de exportación, generación de clúster y planes de innovación de manera que se fomente los estándares de calidad y certificaciones a los procesos productivos de exportación.

Pilar 3: Facilitación del comercio exterior y eficiencia de la cadena logística internacional.

Para convertir al Perú en el referente logístico regional e internacional se necesita agilizar y reducir el costo transfronterizo garantizando su protección, seguridad y trazabilidad. Urge la necesidad de lograr una posición competitiva en la dorsal del Pacífico. Según OECD, los costos en transacciones van de $1 \%$ - 15\% y su disminución sería un enorme potencial 
de crecimiento. El Gobierno no repara en esfuerzos en establecer convenio y acuerdos que facilitan el comercio internacional de manera que los empresarios salgan beneficiados con potenciales ingresos.

Pilar 4: Generación de capacidades para la internacionalización y consolidación de una cultura exportadora.

Es necesario promover el desarrollo de capacidades, con cultura exportadora, habilidades innovadoras y creativas con visión a futuro y disposición al cambio. Es necesario afrontar los retos que la globalización trae con mucho esfuerzo y trabajo en equipo de instituciones públicas, privadas y empresarios hará que el comercio exterior del Perú sea el motor de su desarrollo económico competitivo y sostenible.

Dentro del marco del Plan Estratégico Nacional Exportador (PENX 2025) se establecen actividades, mecanismos e instrumentos de facilitación del comercio para el impulso del comercio exterior y por ende el desarrollo

económico del país. Uno de ellos es la Ventanilla Única de Comercio Exterior (VUCE).

\subsubsection{Certificado de Origen y Reglas de Origen en el Sector Textil}

El certificado de origen es un documento comercial que acredita el cumplimiento del origen nacional de las mercancías exportadas según las normas de origen, así también, sirven para acceder a diversos beneficios arancelarios. 
El principal objetivo es garantizar el origen y procedencia de las mercancías, también otorga al importador preferencias arancelarias, brinda ventajas competitivas al exportador.

\section{Importancia de las reglas de origen}

Las reglas de origen nos garantizan que solo las mercancías que califiquen como originarias de las partes del acuerdo comercial se beneficien del tratamiento preferencial.

Se puede determinar de la siguiente manera:

- Mercancías obtenidas enteramente en el país (fabricadas a partir de insumos $100 \%$ originarios).

- Mercancías elaboradas a partir de materiales originarios y no originarios: y cumplen con los criterios de las reglas de origen.

- Mercancías elaboradas a partir de materiales originarios. Las mercancías elaboradas exclusivamente a partir de materiales originarios de una o más Partes.

\subsubsection{Compromisos en el Marco de Acuerdo Multipartes con la UE}


El acuerdo comercial entre Perú y la Unión Europea ha permitido que el Perú obtenga acceso preferencial al mercado europeo para el $99.3 \%$ de su oferta agrícola y el $100 \%$ de sus productos industriales. Los productos de la industria de la vestimenta, es decir, aquellos comprendidos en los capítulos 61, 62 y 63 del Sistema Armonizado, gozan de entrada libre de aranceles al mercado europeo (incluyendo a Francia), es decir, desde la entrada en vigor del Acuerdo de Libre Comercio: el arancel aplicado es equivalente al $0 \%$.

El impuesto al valor agregado (IVA) aplicado a las importaciones en general en Francia es equivalente al $20 \%$ del valor CIF de los productos más los aranceles correspondientes. Dicha tasa es aplicada a los productos de la industria de la vestimenta. Productos tales como alimentos, fertilizantes, y equipo para personas con discapacidad gozan de tasas reducidas de entre $5.5 \%$ y $10 \%$. La información precisa sobre las tasas de TVA vigentes se puede consultar en la web de la Dirección General de Aduanas. (PROMPERU - Servicio al Exportador, 2017, p. 5,6)

\subsubsection{Entidades reguladoras}

En el Perú la entidad reguladora de la cadena logística de salida de productos es la Superintendencia Nacional de Administración Tributaria (SUNAT), institución estatal descentralizada del Sector Economía y Finanzas, se encarga de administrar las actividades en materia tributaria y aduanera en todo el territorio nacional. Sus atribuciones en temas aduaneros son: 
- Controlar y fiscalizar el tráfico internacional de mercancías tanto la entra o salida de las mismas, ejecuta sistemas de análisis y fiscalización de las mercancías en el territorio nacional, previene persigue y denuncia el contrabando y el tráfico ilícito de mercancías.

- Difunde, determina y recauda los derechos arancelarios sobre las importaciones según los tratados y convenios vigentes en materia aduanera, recauda tributos aduaneros y ejecuta medidas que cautelan la percepción de los mismos.

- Realiza estadísticas de tráfico internacional de mercancías, sistematiza y ordena la legislación e información estadística de comercio exterior para su respectiva difusión.

En Francia, la entidad reguladora es la Dirección General de Aduanas de Francia (DGDDI), es el órgano de control adscrito al Ministerio de Finanzas y Cuentas Públicas que administra las operaciones en materia aduanera, tiene una red de 200 oficinas y 270 unidades de vigilancia.

Sus funciones son las siguientes:

- Ejecuta el control aduanero mediante la fiscalización y vigilancia de la entrada y salida de mercancías y los medios de transporte. 
Monitorea y combate el flujo de mercancías peligrosas e ilegales y los riesgos de fraude.

- Fiscaliza el cumplimiento de las normas y regulaciones de la Unión Europea en materia comercial y sanitaria en el marco de organización Mundial del Comercio.

- Recauda los impuestos de comercio exterior y valor agregado dispuestos por la Unión Europea así como los aplicados al tabaco, alcohol y petróleo.

- Difunde las estadísticas de comercio internacional de mercancías para su utilización de los sectores privados y públicos.

\subsubsection{Medidas arancelarias}

En cuanto a las tarifas arancelarias, el gobierno francés aplica las reglas de la Unión Europea. El comercio dentro del territorio de la UE está exento de tarifas arancelarias. Si el país exportador no es miembro de la UE, las tarifas arancelarias se calculan en base Advalorem sobre el valor CIF de las mercaderías según las Tarifas Arancelarias Generales. 
El acuerdo comercial que el Perú tiene con la Unión Europea permite el acceso al $100 \%$ de productos industriales con $0 \%$ de arancel.

\subsubsection{Medidas No Arancelarias}

La Unión Europea tiene una red de normativas para regular la seguridad de las personas, animales y el medio ambiente comunes a todos los países miembros.

Las principales normativas son:

\section{a) Protección del medio ambiente:}

Las normativas de protección a la naturaleza que se enmarcan en el sexto programa de Acción Comunitario en Materia de Medio Ambiente, el que trata, entre otras cosas, sobre: sustancias y productos químicos, sustancias que dañan la capa de ozono, gases fluorados de efecto invernadero, detección de especies amenazadas, control y gestión de residuos, entre otros.

\section{b) Certificaciones la Asociación Francesa de Normalización}

(AFNOR) es el organismo que lleva a cabo las distintas iniciativas de estandarización técnica en Francia. Promueve la marca "NF" (Norme francaise), la cual cuenta con un gran conocimiento de la población. Esta certificación asegura que el producto cumpla con los requisitos 
de calidad y seguridad exigidos en Francia. Existe también una certificación similar de carácter europeo llamado "CE". Otra certificación en uso en Francia es la marca AB (Agriculture Biologique), que certifica que el producto es de origen orgánico, que se usa principalmente en productos agroindustriales.

\section{c) Etiquetados:}

Las etiquetas deben incluir como mínimo: origen, contenido, composición, utilización segura, precauciones especiales, e informaciones específicas de los diferentes productos. Para ser comercializadas en Francia la etiqueta debe estar escrita en francés, aunque también se recomienda la utilización de otros idiomas. La Directiva 2000/13/CE del Parlamento Europeo regula la implementación de normas de etiquetado, presentación y publicidad de los productos. Una guía detallada de las normas de etiquetado se encuentra disponible en la Síntesis Legislativa de la Unión Europea

Por su parte, desde el 1 de julio de 2011, se inició la marcha blanca de la Ley de Protección al Medioambiente (Ley Grenelle), la cual busca incorporar al etiquetado de los productos de consumo masivo información sobre el impacto ecológico de estos a través de la Huella de Carbono. (Promperú - Servicio al Exportador, 2014, p. 9). 


\subsubsection{Ferias Internacionales}

Existen innumerables ferias a las que los exportadores pueden participar como las siguientes:

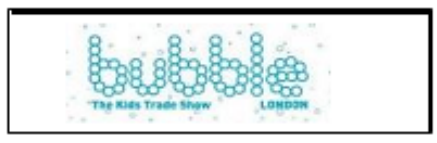

Feria Bubble London 28-29 Enero - Londres Reino Unido

\section{PREMIEREVISION \\ NEW YORK}
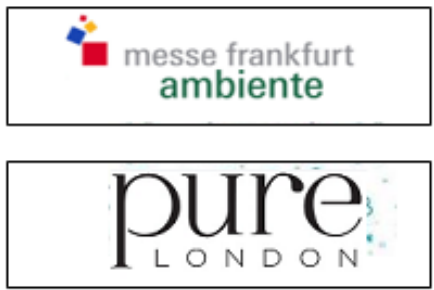

PerúMODA

Asia $\mathbf{2 0 1 8}$ Tolyyo- Seoul- Bejling - Shangh
Feria Premiere Visión 16 - 17 de Enero - Nueva York EEUU

Feria Ambiente 09 - 13 febrero - Frankfurt Alemania

Feria Pure London - 11-13 Febrero - Londres Reino Unido

Misión Perú Moda en Asia: Seul y Tokio 


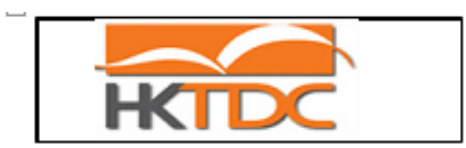

Feria Hong Kong International Jewellery Show - 26 de febrero al 03 de marzo

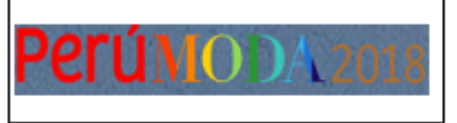

Rueda de Negocios PM\& PGS - 18-20 abril - Lima Perú

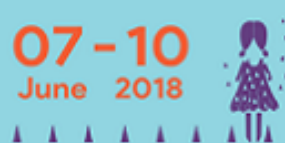

Feria Fit - 07-10 junio - Sao Paulo Brasil

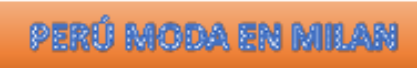

Misión Comercial y Rueda de Negocios - Junio - Italia

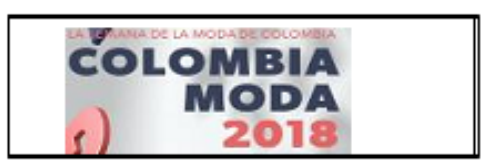

Feria Premiere Vision - Julio - Nueva York , EE.UU

\section{PREMIEREVISION}

Feria Premiere Vision - Julio - Nueva York , EE.UU

Feria The Hotel Show Dubai-16-18- setiembre Dubai EAU

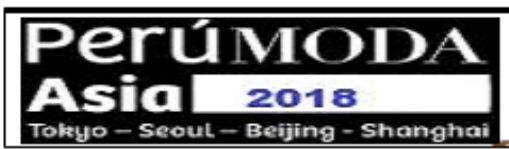

Misión Perú Moda en Asia:Beijing - setiembre Beijing China

Rueda de Negocios - 22-27 octubre - Arequipa Perú

\section{PEBO MODA BAANL} - Porto Alegre Brasil
Misión Comercial y Rueda de Negocios - Oct- Dic 


\subsection{Factores críticos de éxito}

\subsubsection{Definición}

Desde el punto de vista de los negocios, Lusthaus y otros (2002) afirman que el éxito es:

"Un resultado favorable de un programa o proyecto que se evalúa en términos de consideraciones como la efectividad, la repercusión, la sostenibilidad y las contribuciones al desarrollo de la capacidad" (Lusthaus, 2002, p.200).

De acuerdo con Johnson, G. y Scholes, K. (2002, p. 151), "Los factores críticos de éxito son aquellos componentes de la estrategia en los que la organización debe tener éxito para superar a los competidores". Es decir que el valor agregado del producto es considerado como una característica esencial para tener éxito y superar a los competidores.

Por otra parte, Lynch, considera que son los recursos, habilidades y atributos de una organización que son esenciales para tener éxito en el mercado. (Lynch, 2003:102). Por lo que determinar correctamente estos factores clave es muy importante para que las empresas tomen decisiones de estratégicas.

Según John F. Rockart, Director del Centro de Investigación de Sistemas de Información, Escuela de Sloan de Administración del Instituto Tecnológico de Massachusetts, asimismo catedrático sobre planeación, control y sistemas de información gerencial en dicha escuela, los FCE, como se abrevia Factores Críticos de 
Éxito, vienen a ser un número limitado de áreas en donde los resultados que se obtenga si son satisfactorios, se asegurará un funcionamiento competitivo para la organización.

Los FCE son específicos para cada negocio y reflejan las preferencias gerenciales respecto a las variables claves en un determinado momento. Debemos distinguir entre FE (Factores de Éxito) y FCE, ya que el primero dice que algo que debe ocurrir, o no debe ocurrir, para conseguir un objetivo, mientras que el segundo se dice que es crítico porque es necesario su cumplimiento para los objetivos de la organización.

Los FCE se pueden aplicar a cualquier empresa que forme parte de una industria en particular, teniendo en cuenta que el sistema de control administrativo debe adaptarse a las necesidades específicas de una compañía. Esta posibilidad nos sugiere que no sólo la industria origina aspectos que son determinantes para el funcionamiento adecuado de una organización. Hay cuatro fuentes esenciales que dan lugar a estos factores: (Rockart, J., 1979, pp.8)

- Estructura de la industria particular: tal y como observamos, cada industria se ve caracterizada por una serie de aspectos decisivos que son propios de ella y que son particularmente importantes para toda organización.

- Estrategia competitiva: posición de la industria y ubicación geográfica. Toda compañía que forma parte de una industria se ve condicionada por su historia y por la estrategia que emplee en un momento dado. En el caso de las empresas pequeñas que se mueven dentro de una industria que está dominada por una o dos grandes compañías, las circunstancias varían ya que el comportamiento de estas últimas repercutirá sobre las de menores dimensiones. 
- Factores ambientales: al igual que existen fluctuaciones en relación con el PBI, la economía, las circunstancias políticas y la población, también las causas que fundamentan el éxito pueden diferir de una institución a otra. Hay puntos que son vitales para la construcción de los objetivos de la organización.

- Factores temporales: al hacer un análisis interno de la organización es posible determinar los factores temporales que son cruciales para el éxito. Nos referimos a ciertas áreas de actividad que son determinantes para el buen funcionamiento de una empresa durante un cierto periodo porque se encuentran por debajo del límite de aceptabilidad en ese momento (aún cuando en general están en buenas condiciones y no merecen especial atención).

\subsubsection{Factores Críticos de Éxito en la exportación}

El decidir a qué país o mercado dirigirse para exportar sus productos, es una tarea difícil que implica una gran responsabilidad pues de esto dependerá el fracaso o éxito del negocio.

Desde el punto de vista de los negocios definidos por Lusthaus y otros (2002), existen algunas claves a seguir en el proceso de la exportación de mercancías para que se logre exitosamente. También puede ser aplicado al mercado de exportación, es decir que temas o asuntos claves deben tenerse en cuenta para lograr el éxito en las exportaciones.

Según el libro "Las claves para exportar con éxito" elaborado por Soluciones Logísticas Mundiales Costa Rica (SLMCR), se consideran categorías para analizar los factores críticos de éxito, estas claves son: 


\subsubsection{Definir el destino}

La elección del mercado al que se quiere dirigir va ser clave, ya que en primer lugar, se deberá tomar en cuenta los aspectos del país elegido como estabilidad política, económica, relaciones económicas con otros países, grados de apertura comercial, políticas arancelarias, aduaneras y niveles de corrupción.

Debido a que todo proceso tiene riesgo y lo que se quiere es anticiparnos a cualquier cosa que pueda suceder.

\subsubsection{Analizar la competencia}

Parte de la investigación que se debe realizar es estudiar la competencia, de esta manera se pueden prever inconvenientes innecesarios.

Se debe dedicar un tiempo prudencial a analizar la forma en que operan las empresas que serán la competencia en el país donde se quiere establecer, por ejemplo, analizar ¿qué hacen?, ¿cómo lo hacen?, y buscar la manera de que se pueda mejorar eso, claro sin dañar la calidad del producto nuestro, la idea es ofrecer un producto mejor.

\subsubsection{Documentación}

Para ser exportador en todo país, es necesario cumplir con requisitos básicos, para lo que una agencia de aduanas certificada en el rubro exportador puede ser de utilidad para realizar los trámites necesarios. Luego de esto, internamente la empresa exportadora, debe llevar el orden y control con los datos del cliente (su dirección, teléfonos, email y otros) 
y los datos del producto que se está trasladando como la cantidad, tamaño del paquete, peso, tipo de transporte en el que va, etc.

\subsubsection{Plan financiero}

Exportar no es un proceso que lleva sus implicaciones económicas, para lo cual antes de lanzarse a exportar se debe tener un presupuesto financiero y un plan de contingencia en caso de que alguna cosa saliera mal o en caso de que se necesite más dinero para seguir exportando. Por último, cabe recalcar que toda la información detallada, son ayudas que permitirán desarrollar y tener una mejor visión del mercado al cual dirigirse.

\subsubsection{Transformación y competencia en el mundo}

Para conseguir el éxito de una empresa no sólo es revisar o supervisar las actividades operativas propias del negocio sino es realizar el seguimiento desde que se inicia la solicitud del bien o servicio hasta incluso después de la venta y post venta. Se debe realizar una autoevaluación a nivel empresarial a fin de poder detectar las fallas o deficiencias en alguno de los procesos del negocio y si hubiera es sumamente relevante realizar cambios o conversiones para reestructurar los procesos o áreas pertinentes al problema.

En efecto, así como la mayoría de las personas tienen miedo al cambio a tal punto que se resisten a ello. De igual modo sucede en las empresas y/o con los empresarios tal es 
así que a pesar de tener inconvenientes en ciertas áreas o en ciertos temas no se muestran dispuestos a buscar una solución a través de cambios, conversiones, reconversiones o transformaciones que a corto, mediano y largo plazo serán favorables al negocio.

El cambio o una reconversión se deben ver como una oportunidad de crecimiento a través de un proceso de ajuste constante que brindará futuro a la empresa. Desarrollando las nuevas capacidades de los colaboradores y directivos en todas las áreas de manera objetiva y profesional, la reconversión será victoriosa, eliminando las obstrucciones o cuellos de botella que hará frente la gerencia general (Biasca Rodolfo E., Paladino Marcelo, 1991).

Para dar el primer paso de la reconversión se debe saber con certeza los orígenes y la magnitud del desajuste empresarial. Son tres las variables claves de competencia las cuales servirán para analizar la situación actual empresa detectando las anomalías y la envergadura de estas, que impiden el crecimiento competitivo del negocio. Las variables son calidad, tecnología y productividad, las cuales se pueden cuantificar y comparar en el tiempo de manera que la gerencia pueda tomar decisiones acertadas pare el éxito de la empresa (Biasca Rodolfo E., Paladino Marcelo, 1991).

La reconversión tiene por objetivo preservar la competitividad de la empresa a largo plazo. La reconversión es un gran sacrificio de largo aliento que se edifica y se sostiene por toda la organización. Para ser competitivo se debe aprovechar de manera correcta los recursos, habilidades y fortalezas organizacionales creando una o diversas ventajas frente a la competencia (Biasca Rodolfo E., Paladino Marcelo, 1991). 


\subsubsection{Principales factores identificados}

A lo largo de los estudios académicos, experiencias, capacitaciones, charlas, diplomados y el paso del tiempo el ser humano va adquiriendo madurez, sabiduría, habilidades y destrezas que lo harán convertirse en líder empresarial capaz de llevar las riendas del negocio al éxito competitivo del mundo actual. Por medio de ello, brindarán empuje al crecimiento de los países, crecimiento que también se debe ver reflejado en la población y en la población de otros países, que también intervienen en el comercio internacional. El comercio internacional debe tener por objetivo el crecimiento económico de los países participantes, pero ello, a veces no se cumple, porque aún hay países pobres.

La desigualdad es considerable en ciertos países pobres, pero poseen coincidencias hacia el progreso y potencial crecimiento que puede incrementar debido a políticas correctas que se aplican para generar relevantes ingresos que repercutan en la población. El comercio internacional debe promover el crecimiento económico de los países.

La desigualdad se ha dado en gran medida al cambio tecnológico que debe ir de la mano del comercio internacional. Cambios que tienen que reflejarse en las empresas de todos los países si desean ser competitivos y generar grandes ingresos para el negocio y a su vez, para su país y sus habitantes. Si las empresas o países no se actualizan con los cambios tecnológicos de la industria y del comercio internacional no tendrán futuro exitoso (FMI, 2017). 
La investigadora, docente y jefa del Laboratorio Textil de Confecciones de la Universidad de Lima, Rosa Patricia Larios Francia, brindó una conferencia en el Primer Congreso Internacional Textil e Industria de la Moda Perú 2017 realizado del 20 al 25 noviembre en la Universidad Nacional Mayor de San Marcos, bajo la organización de la Escuela Profesional de Ingeniería Textil y Confecciones de dicha institución, manifestando que no se debe temer a la innovación porque sólo se trata de una nueva oferta de valor viable; se debe innovar en distintos procesos del rubro textil, como en la prenda, producción, mercadotecnia y la organización para crear valor a la empresa y enfrentar la competencia en este mundo globalizado.

En consecuencia, los factores que determinan la competitividad de una empresa son; la tecnología, calidad y productividad que ligado a las habilidades de los colaboradores, serán la base del éxito del comercio en este mundo competitivo y cambiante. Es decir, si no se es competitivo, no existes en el mundo de los negocios y por lo tanto, no habrá éxito empresarial. Así mismo, sucede con los países sino se realizan acuerdos comerciales entre países y se toman políticas de intercambio comercial con apertura a mercados entonces la economía del país, de las empresas y de sus habitantes no crecerá. 


\section{CAPÍTULO II: METODOLOGÍA DE LA INVESTIGACIÓN}

\subsection{Planteamiento del problema}

\subsubsection{Finalidad de la investigación}

El propósito de la presente investigación, es demostrar que existen factores críticos de éxito que posicionan a la empresa exportadora de ropas de baño y bikinis para damas al mercado francés, consolidándola en un nivel de alta competitividad, que el globalizado mundo actual requiere. Asimismo, servirá como base de estudio para futuros investigadores del sector textil de ropas de baño y bikinis para damas al mercado francés.

\subsubsection{Objetivos de la investigación}

\section{Objetivo general}

Determinar los factores críticos de éxito que consolidan el posicionamiento comercial de la exportación de ropas de baño y bikinis desde Lima-Perú a Francia.

\section{Objetivos específicos}

1. Realizar el análisis de los factores críticos de éxito en el proceso de exportación.

2. Identificar las formas de entrada del producto, políticas de comunicación y documentación necesaria para la exportación del producto.

3. Identificar la viabilidad de un plan de innovación tecnológica e implementación de los canales de venta y distribución de ropas de baño y bikinis a Francia. 
4. Definir la competitividad de la empresa en el mundo.

\subsubsection{Interrogantes de la investigación}

\section{Interrogante principal}

¿Cuáles son los factores críticos que determinan el posicionamiento de la oferta de ropas de baño y bikinis para damas en el mercado francés?

\section{$\underline{\text { Interrogantes secundarias }}$}

- ¿Existe suficiente capacidad de producción exportable?

- ¿Poseen un diseño adecuado de marketing?

- ¿Carecen de recursos, equipos tecnológicos y capacidad innovadora para la exportación a nuevos mercados?

- $\quad$ Existe mano de obra especializada y calificada para el proceso productivo?

- ¿Carecen de un plan de distribución y canales de venta a nivel internacional?

- ¿Hay barreras de índole no arancelaria que impiden el proceso de exportación?

\subsubsection{Justificación de la investigación}

Con el resultado del análisis del estado actual de la oferta exportable de ropas de baño y bikinis para damas hacia el mercado francés, se podrá transmitir 
información relevante sobre la coyuntura de producción, manufactura, comercialización y exportación. Dicha información permitirá conocer las deficiencias, asertividades y hallazgos que permitirá a los exportadores reorganizar sus procesos productivos y de comercialización para consolidar el posicionamiento de la exportaciones peruanas en el rubro textil de bañadores.

\subsubsection{Hipótesis de la investigación}

La hipótesis es una presunción o suposición que hace el investigador durante el estudio o al final de éste, sobre el resultado de la investigación, pero la hipótesis puede variar o afinar a lo largo del estudio.

Según Hernández Sampieri,, las hipótesis se van generando durante el proceso, se afinan a medida que recopilan datos y se pueden modificar según los resultados.

En la presente investigación, se parte de las siguientes hipótesis:

\section{Hipótesis General}

Existen trabas no arancelarias para el ingreso de ropas de baño y bikinis a Francia.

\section{Hipótesis específicas}

a. Existen obstáculos técnicos al comercio que estarían impidiendo el ingreso de ropas de baño y bikinis a Francia.

b. Existen obstáculos aduaneros en VUCE, facilitación del comercio, documentación, trámites innecesarios, inspecciones, licencias de 
importación entre otros que no facilitan el ingreso de ropas de baño a Francia.

c. La ausencia de conocimiento de las ventajas del acuerdo comercial con la Unión Europea en materia de reglas de origen para la exportación de ropas de baño y bikinis para damas.

d. La carencia de un adecuado diseño de marketing internacional es un factor determinante para el posicionamiento comercial de la exportación de ropas de baño y bikinis a Francia.

e. La ausencia de tecnología e innovación para los exportadores de ropas de baño y bikinis a Francia afecta la competitividad del producto.

f. La mano de obra calificada constituye un factor determinante en la exportación de ropas de baño y bikinis a Francia.

g. La deficiente implementación de canales de venta y distribución afecta negativamente la exportación de ropas de baño y bikinis al mercado de Francia.

\subsection{Metodología de la investigación}

La presente investigación, busca analizar de manera profunda y detallada el entorno global económico de la industria textil en el rubro de ropas de baño y bikinis para damas, tanto en el Perú como en el mercado de destino, Francia. En el capítulo I se muestra datos cualitativos de variadas fuentes de información que nos dan a conocer el estado actual de la oferta exportable. Pero muy a nuestro pesar, aún no se han realizado investigaciones que nos puedan brindar mucha más información formal y científica del sector ropas de baño y bikinis para damas. 
Asimismo, con la presente investigación, se identifica información detallada, acorde con la realidad que viven los exportadores, importadores y entes del comercio exterior peruano y francés, analizando la coyuntura y el contexto de su desenvolvimiento en el comercio internacional de manera precisa y objetiva.

Por todo lo expuesto, el entorno de la investigación aplica al uso de la metodología cualitativa; metodología que busca mostrar la realidad de uno o varios sectores comerciales que interrelacionan en un determinado contexto. La investigación científica se define como un grupo de procesos sistemáticos y empíricos que permiten el estudio de un fenómeno, que puede ser cambiante, dinámica y evolutiva (Hernández, 2014).

En la investigación cualitativa se examinan los fenómenos al detalle para determinar su esencia, formando interpretaciones, implica muchos datos que involucran su abstracción y reducción. Además del resultado del análisis, se obtienen hallazgos, se pueden hacer descripciones, clasificar conceptos de manera ordenada construyendo una teoría. El análisis cualitativo no sólo es una ciencia sino también un arte, que sin este componente sería un hallazgo estéril y sin creatividad (Universidad Autónoma de Aguas Calientes, 2010)

Lo relevante del método cualitativo es la concepción del ámbito social como una realidad construida por articulaciones de diferentes dimensiones sociales y culturas sistematizadas que tienen la propiedad de ser diferentes a las leyes naturales (Guerrero D.G., 2014). 
En la presente investigación, los factores críticos de éxito son elementos o componentes clave de una organización que se expresan en variables, que en cierto momento se tornan críticos pero cuando se realiza un buen manejo de estas variables se transforman en una posición competitiva exitosa para la empresa.

El Gobierno Peruano ha desarrollado un plan nacional proyectándose al futuro prometedor y exportador del país. Se publicó por primera vez, en el 2003, el Plan Estratégico Nacional Exportador (PENX) 2003 - 2013, y fue actualizado mediante Resolución Ministerial N³77-2015, de fecha 09 de diciembre del 2015, como Plan Estratégico Nacional Exportador 2015 - 2025.

A través de este documento, se ha obtenido importantes logros en materia exportadora para el Perú, que han configurado un entorno de nuevas oportunidades para las empresas y productos del país en los mercados internacionales. El marco del PENX presenta 4 pilares muy relevantes como son los siguientes mencionados en el capítulo anterior.

- Pilar I: Internacionalización de la empresa y diversificación de mercados.

- Pilar II: Oferta exportable, competitiva y sostenible.

- Pilar III: Facilitación del comercio exterior y eficiencia de la cadena logística internacional.

- Pilar IV: Generación de capacidades para la internacionalización y consolidación de una cultura exportadora.

Teniendo como base el PENX 2025 y sus pilares estratégicos se formó tres dimensiones por las cuales se analizará la información primaria recogida de los actores intervinientes 
en las operaciones de comercio exterior. Dimensiones que buscan dar a conocer la capacidad productiva, ventajas competitivas de la oferta exportable, barreras arancelarias y no arancelarias y proceso logístico al que se enfrenta, así como también el comercio y demanda internacional de ropas de baño y bikinis al mercado francés.

\subsection{Muestra de la investigación}

Se ha podido definir, que nuestra muestra va acorde con una investigación cualitativa, en donde buscamos mostrar la realidad de diferentes sectores que están relacionados en un mismo contexto, por lo que hemos seleccionado a nuestros entrevistados de la siguiente manera, sector público, sector exportador y sector de importadores; teniendo pleno conocimiento del tema a tratar, y dándonos un gran aporte para la investigación, por lo que hemos escogido detalladamente a nuestros sectores para obtener un resultado certero.

\subsection{Acceso al mercado}

El contexto donde se realiza el estudio y levantamiento de información primaria es en la ciudad de Lima, ya que, es allí donde se encuentran la mayoría de actores del comercio de ropas de baño y bikinis a Francia. Se establecieron contactos y se reservaron entrevistas con los distintos actores mediante el uso de distintos canales de comunicación que el mundo actual permite.

\subsection{Diseño de la investigación}




\subsubsection{Segmentos de la investigación}

Hemos podido segmentar a nuestros actores en los siguientes sectores:

\section{Sector 01: Sector Instituciones Públicas}

En el Gobierno Peruano, existen diversas instituciones que se encargan de facilitar las operaciones de comercio exterior mediante la realización de diversas actividades al interior y exterior del país. Asimismo, realizan convenios y acuerdos con diferentes instituciones públicas y privadas, de manera que, las empresas exportadoras tengan un abanico de opciones de apoyo en el desarrollo del comercio internacional. Dentro de las instituciones públicas tenemos al Ministerio de comercio Exterior y turismo, PROMPERU (Comisión de Promoción del Perú para la Exportación y el Turismo) y SUNAT (Superintendencia Nacional de Aduanas y de Administración Tributaria).

\section{Sector 02: Sector Exportador}

En el Perú existen diversas empresas exportadoras de ropas de baño y bikinis para damas, que realizan intercambio comercial con diversos países de América, Asia, Europa y Oceanía, pero no todos exportan al mercado francés. Dentro de las principales empresas exportadoras tenemos Applauzi SAC, Toque D'sol SRL., ARDIMO SRL., Capittana RS SAC., Beso de Sal, entre otras.

\section{$\underline{\text { Sector 03: Sector Importador }}$}

Este sector es de difícil acceso, ya sea por la distancia, contacto, tiempo y economía. Existen varios importadores franceses que realizan intercambio 
comercial con los exportadores peruanos, pero sólo el Importador Sarl Vega accedió a ser entrevistado. Este importador realiza intercambio comercial con la empresa Applauzi SAC.

\subsubsection{Dimensiones}

Tomando en cuenta los pilares estratégicos del PENX se determinaron las siguientes tres dimensiones que ayudarán a recibir la información de manera ordenada y precisa para su respectivo análisis.

Dimensión 1: Capacidad productiva y ventajas competitivas de la oferta exportable de ropas de baño y bikinis para damas.

Dimensión 2: Barreras arancelarias y proceso logístico de la oferta exportable de ropas de baño y bikinis para damas.

Dimensión 3: Comercio y demanda internacional de la oferta exportable de ropas de baño y bikinis para damas.

\subsubsection{Instrumentos de la Investigación}

Hemos seleccionado a la entrevista como instrumento principal para nuestra información primaria; con la finalidad de conocer más sobre cada uno de los segmentos elegidos previamente, los cuales están relacionados con el tema a investigar, y nos brindan una experiencia de poder conocer más sobre el tema, intercambiar información y solucionar dudas. 


\subsubsection{Procedimiento de la investigación}

Se comenzó el proceso de investigación mediante el seguimiento de varios pasos:

Paso 1: Identificar a los especialistas que puedan brindar su conocimiento, experiencias y apreciaciones del sector.

Paso 2: Establecer un primer contacto vía telefónica y/o correo electrónico.

Paso 3: Reserva de la fecha de la entrevista.

Paso 4: El especialista accedió a ser grabado y brindó las facilidades del caso, sólo dos especialistas permitieron la grabación de audio.

Paso 5: Se contactó con innumerables especialistas del sector público, sólo ciertos especialistas nos pudieron brindar información específica de acuerdo a las preguntas de la entrevista, otros brindaron referencias generales del sector textil.

Paso 6: Los especialistas como los representantes de la Oficina Comercial Regional de Gamarra y de la Dirección General de Negociaciones Comerciales Internacionales (MINCETUR) fueron muy amables en brindar información idónea que daba respuesta a las preguntas de la entrevista.

Paso 7: Se estableció contacto con varias empresas exportadoras pero no todas respondieron a nuestras solicitudes.

Paso 8: La principal empresa exportadora de prendas de baño para damas tuvo la gentileza de recibirnos en sus instalaciones y fue una entrevista sumamente enriquecedora. 
Paso 9: Respecto a los importadores, se estableció un primer contacto por correos electrónicos pero no se obtuvo respuesta, es un sector que se encuentra lejos geográficamente y complejo de contactar si es que no hay un exportador que sea intermediario de la comunicación. Estamos a la espera de la respuesta de este sector.

Paso 10: Toda la información recabada de diferentes medios de comunicación de las entrevistas realizadas ya sea de video y audio fue plasmada en la bitácora estableciendo observaciones y hallazgos de acuerdo a la clasificación establecida de sectores y dimensiones.

Paso 11: Se analizaron las respuestas y se identificaron aportes y hallazgos importantes de las múltiples entrevistas.

Paso 12: Se identificaron relaciones de acuerdo a la experiencia de los entrevistados acorde a cada sector y dimensión que permitirá determinar las conclusiones y recomendaciones. 


\section{CAPÍTULO III: ANÁLISIS DE INFORMACIÓN Y RESULTADOS}

En este capítulo, se detalla la información recabada de diversas entrevistas estructuradas de acuerdo a cada sector y dimensiones que tienen como base los pilares del PENX; obteniendo diversos resultados de un proceso cualitativo en donde podemos identificar diferentes estrategias relacionadas al tema de investigación, y, mejorar e incrementar nuestra participación de mercado en el país de Francia.

Las preguntas fueron adecuadas, según al grupo de especialistas, exportadores y dimensiones correspondientes para obtener respuestas precisas para el trabajo de investigación.

\subsection{Sector 1: Instituciones públicas}

\subsubsection{Dimensión 1: Capacidad productiva y ventajas competitivas de la oferta exportable de ropas de baño y bikinis para damas.}

Francia es un mercado competitivo, exigente, de buen vestir y con las últimas tendencias.

Según la información obtenida, los importadores franceses establecen acuerdos comerciales de manera formal, responsable y en los plazos establecidos, así como también, en los pagos y el cumplimiento de la negociación. 
Hasta el momento, vienen respondiendo al comercio de ropas de baño y bikinis, lo que se puede verificar en las estadísticas, siendo un rubro en crecimiento.

Asimismo, se ha podido verificar e informarnos conforme a las respuestas obtenidas, que Brasil, Colombia y Chile tienen mayor desarrollo en el rubro por la alta tecnología que emplean, por realizar ferias de proveedores y por tener el gran apoyo de sus gobiernos.

Los países de Brasil y Colombia han desarrollado de manera compacta el rubro textil gracias a las sinergias de los entes, a la organización de las cadenas productivas y creando tendencias para el mundo; por lo que han logrado el reconocido lugar en el cual se encuentran.

Las amplias estaciones veraniegas y lugares turísticos cercanos en el Caribe y el Pacífico confluyen para el crecimiento comercial del rubro ropas de baño y bikinis para damas.

Las ventajas competitivas que se pueden apreciar en las empresas que han logrado un intercambio comercial con los importadores franceses, son; la calidad, tendencia y capacidad productiva, así como, contar con una respuesta inmediata del importador; en lo cual deberíamos proponer una mejor variedad de prendas con valor agregado a precios asequibles. 


\subsubsection{Dimensión 2: Barreras arancelarias y proceso logístico de la oferta exportable de ropas de baño y bikinis para damas.}

En esta dimensión hemos podido informarnos que no existen barreras no arancelarias, tan sólo, si en algún momento el cliente solicita ciertas certificaciones, además de cumplir con las reglas de etiquetado, rotulado y documentos propios de la exportación, no habría alguna otra restricción.

En el Perú, el transporte, el proceso logístico y control de tiempos es una de las falencias en el proceso de exportación con respecto a otros países, debido a que en otros países en el menor tiempo posible realizan traslados, cargas y descargas de mercancías a precios competitivos. Asimismo, se exporta mediante la vía aérea por la rapidez, bajo costo en comparación de la vía marítima, y porque la mercancía ocupa el menor peso y volumen.

El Acuerdo Comercial Multipartes entre Perú y la UE, que establece una zona de libre comercio entre ambas partes, trajo consigo la rebaja arancelaria sobre la base de la regla de origen; las cuales son las siguientes:

1. Mercancías obtenidas enteramente en el país (fabricadas a partir de insumos $100 \%$ originarios).

2. Mercancías elaboradas a partir de materiales originarios y no originarios: y cumplen con los criterios de las reglas de origen. 
3. Mercancías elaboradas a partir de materiales originarios. Las mercancías elaboradas exclusivamente a partir de materiales originarios de una o más Partes.

Además, se necesita renovar, modernizar y ampliar las instalaciones portuarias, de manera que mejore la afluencia y la competitividad del comercio exterior; así como, crear la oferta de precios competitivos que incentive al crecimiento de las operaciones de comercio exterior.

El exportador ayudará en el proceso de exportación, si tiene una empresa organizada en los procesos operativos, administrativos y con la formalidad que el caso requiere. Además, debe tener claro, a donde desea llegar y cómo lo realizará, es decir, tener capacidad de gestión empresarial para entablar negociaciones con el mercado interno y externo a todo nivel.

Las instituciones públicas y privadas, seguirán brindando capacitaciones, asesorías, convenios y programas en los cuales participen los empresarios y de esa manera apoyen a la internacionalización de las empresas.

Cabe recalcar, que el Gobierno tiene destinado una determinada cantidad de dinero para promover actividades de comercio exterior, pero siempre se van a necesitar más recursos para apoyar a más empresas. Mincetur 
busca optimizar cada recurso analizando si fue útil de manera cuantitativa la realización de ferias y ruedas o misiones de negocio para mejorar sus indicadores actuales.

\subsubsection{Dimensión 3: Comercio y demanda internacional de la oferta exportable de ropas de baño y bikinis para damas.}

El crecimiento se debe a la capacidad de respuesta, al conocimiento previo del mercado, alineación a gustos, preferencias y tendencias.

Las ferias son relevantes y es una buena oportunidad para los planes de internacionalización de una empresa.

Mincetur ha lanzado un programa de apoyo a la internacionalización para que participen las empresas con objetivos claros de inversión en el extranjero. Programa con un fondo de 25 millones de soles para ser invertidos en proyectos concretos de comercio exterior.

Las capacitaciones brindan apoyo, soporte, herramientas, capacidad de gestión y de ventas para el desenvolvimiento empresarial.

El $\mathrm{PAI}^{1}$; tuvo una primera selección de ganadores que comprende a 7 empresas que destacaron por su nivel de ventas, capacidad productiva e

\footnotetext{
1 El Programa de Apoyo a la Internacionalización que promueve MINCETUR es un fondo concursable a través de proyectos de comercio exterior para exportadores con buen desempeño comercial.
} 
indicadores económicos. Una de las empresas ganadoras fue Applauzi; dicha empresa diseño un Proyecto de Franquicias en México con la marca Agua Clara.

Las empresas que destacan son Applauzi, Toque D'sol, Capittana.

Las actividades que deberían realizar son: crear sinergias de las cadenas productivas, trabajando de la mano con los exportadores, asesores de diversas instituciones públicas, gremios del rubro, proveedores, etc.

Asimismo, se debería realizar el seguimiento de las reuniones de negocios internacionales hasta que se concrete, aprovechando las oportunidades de negocio que en el mercado que se presenten.

\subsection{Sector 2: Exportadores}

\subsubsection{Dimensión 1: Capacidad productiva y ventajas competitivas de la oferta exportable de ropas de baño y bikinis para damas}

Francia, es un sector que está en pleno crecimiento en el rubro de textiles de ropas de baño y bikinis para damas, ellos envían estas prendas importadas a todas partes del mundo con sus diversas marcas; estas prendas cuenta con una alta calidad, ya que es un mercado exigente. 
El Perú está calificado como outsourcing de las empresas extranjeras, fabricando para ellas pero no con una marca propia, son pocas las empresas que invierten en desarrollar una marca en el exterior.

Las empresas peruanas cuentan con gran capacidad productiva, pero hay ciertos momentos donde se presentan cuellos de botella en el mercado interno, pero eso no impide el cumplimiento con el mercado exterior.

En el negocio de ropas de baño y bikinis para dama, Brasil es el país más avanzado seguido de Colombia y Argentina, los cuales ocupan el segundo lugar, en el tercer lugar se encuentra Uruguay y en el cuarto lugar lo ocupa Perú y Paraguay.

Asimismo, los empresarios deben organizarse de tal manera que creen una sinergia con sus proveedores, importadores, colaboradores, gremios e instituciones públicas.

La ventaja competitiva que tienen los exportadores peruanos es que están catalogados como productores de prendas de calidad.

3.2.2. Dimensión 2: Barreras arancelarias y proceso logístico de la oferta exportable de ropas de baño y bikinis para damas. 
Barreras no arancelarias no existen, sólo deben cumplir con los documentos de exportación de acuerdo a las reglas de origen que corresponden a cada destino, para que el proceso de exportación sea exitoso, por lo que se necesita de apoyo financiero, tener claro el fitting o pruebas de defensa de las prendas y asistencia a ferias.

Los bikinis son prendas pequeñas y ligeras que no ocupan mucho espacio y no es tan costoso transportarlas por vía aérea, como sí lo es por vía marítima. El mercado al cual nos dirigimos es un mercado exclusivo y no es masivo.

Ayudó mucho el acuerdo comercial entre el Perú y la UE para generar altos ingresos comerciales.

Actualmente, se importan telas de países europeos como España, Francia e Italia para acogerse a los beneficios arancelarios. El contenido es de $15 \%$ ó $20 \%$ elastano y $80 \%$ a $85 \%$ poliamida.

\subsubsection{Dimensión 3 : Comercio y demanda internacional de la oferta exportable de ropas de baño y bikinis para damas.}

El crecimiento ha sido consecuencia del impulso de la oferta en el mercado externo, al correcto timing (organización y previsión del 
tiempo) y fitting (plasmar lo que se desea mostrar al cliente en una modelo de pasarela).

A los exportadores entrevistados, les gustaría participar en más exhibiciones y ferias especializadas del rubro de ropas de baño y bikinis para damas, porque tienen prendas de calidad y con las ultimas tendencias exclusivas para el exigente mercado internacional.

Asimismo, es muy importante el desarrollo de múltiples ruedas de negocios y ferias internacionales sobre todo que sean especializadas en el rubro, como las de Miami, Francia y New York.

Applauzi ha participado exitosamente en el PAI debido a excelentes indicadores económicos de sus estados financieros y proyecto de inversión de franquicias en México; ya firmaron contrato con Mincetur y están próximos a iniciar las reuniones sobre las operaciones documentarias para ello.

En este evento participaron un total de 200 empresas, de las cuales solo quedaron 7 empresas que cumplían con la formalidad y correcto análisis del proyecto que el caso requiere, que es continuar con la esmerada labor de contactar con clientes potenciales en ruedas de negocios, ferias y misiones internacionales. 
Las principales empresas exportadoras peruanas son Applauzi, Toque D'sol, Capittana, Besos de Sal, Sabz, etc.

\subsection{Sector 3: Importadores}

No hemos podido contactar con ningún importador del país de Francia, se solicitó información de importadores franceses a MINCETUR, sin embargo, esta entidad pública, no pudo ayudarnos, debido a que no brinda información de los importados al público en general; asimismo, se solicitó al Gerente General de Applauzi nos pueda apoyar, enviándoles al importador con el que trabajan unas preguntas formuladas por nosotras, sin embargo, hasta la fecha no hemos obtenido una respuesta positiva. 


\section{CAPÍTULO IV: ANÁLISIS DE RESULTADOS}

En este capítulo, se desarrollará, en base al resultado de nuestra matriz por cada dimensión realizada en cada segmento, a través de un proceso cualitativo, teniendo como objetivo principal, determinar los factores críticos de éxito que consolidan el posicionamiento comercial de la exportación de ropas de baño y bikinis desde Lima-Perú a Francia; y así, proponer estrategias para una mejor exportación del producto.

\subsection{Hallazgos de la investigación}

\subsubsection{Dimensión 1: Capacidad productiva y ventajas competitivas de la oferta exportable de ropas de baño y bikinis para damas.}

Hemos podido concluir que Francia es un mercado sumamente competitivo y exigente en la calidad de sus productos. En el rubro de textil, básicamente en ropas de baño y bikinis para damas, Francia ha comenzado a tener un mayor interés en estas prendas, siendo un rubro en crecimiento.

Asimismo, Francia, al percibir el gran crecimiento y demanda de estas prendas, sus importaciones realizadas, son enviadas a todas partes del mundo con diversas marcas nacionales, teniendo una gran recepción.

Del mismo modo, hemos podido identificar que las empresas peruanas cuentan con gran capacidad productiva, pero hay ciertos momentos 
donde se presentan cuellos de botella en el mercado interno, pero eso no impide el cumplimiento con el mercado exterior.

La ventaja competitiva, que tienen los exportadores peruanos, es que, están catalogados como productores de prendas de calidad.

\subsubsection{Dimensión 2: Barreras arancelarias y proceso logístico de la oferta exportable de ropas de baño y bikinis para damas.}

Si un empresario peruano desea establecer relaciones comerciales con un país europeo, específicamente con Francia, lo primero que debe hacer es tener la imagen de marca como base de buena calidad, acorde a las últimas tendencias y sobretodo, tener un representante comercial con amplios conocimientos, cartera de clientes del rubro textil en el cual se desenvuelven. A medida que van ganando experiencia, pueden incrementar sus ventas a través de la ampliación de la cadena logística mediante la contratación de un distribuidor autorizado, todo dependerá del buen manejo de las operaciones productivas y comerciales en el exterior. 


\subsubsection{Dimensión 3: Comercio y demanda internacional de la oferta exportable de ropas de baño y bikinis para damas.}

El gobierno de Brasil Colombia y Chile invierten promoviendo ferias de productores para que visiten a las empresas y vean todo sobre el rubro.

Prochile y Procolombia envían a sus trabajadores de viaje por todo el mundo para conocer las últimas tendencias en el mercado relacionado al rubro.

\subsection{Barreras de la investigación}

Con el desarrollo del trabajo de investigación y de manera especial con la parte de entrevistas, hemos comprobado, que no existen barreras que impidan establecer intercambio comercial con importadores franceses. Todo se encuentra normado en el Tratado de Libre Comercio Perú-UE y en las Normas de origen de preferencias arancelarias.

\subsection{Brechas de la investigación}

Establecer contacto con los importadores franceses, se convirtió en una brecha a medida que se desarrollaba la investigación, debido a la distancia y el poco o casi ningún acceso a ellos, no permitieron conocer de primera mano sus apreciación de este rubro textil y el intercambio comercial con exportadores peruanos. 
Los representantes de las entidades públicas, no nos pudieron brindar su apoyo para establecer contacto con los importadores, debido a la naturaleza de confidencialidad de sus labores que impiden hacerlo.

A pesar, que por intermedio de un exportador se remitió un primer comunicado, hasta la fecha no se obtiene respuesta, esperamos que en las próximas investigaciones venideras, se logre contactar con uno o varios importadores y se eliminen automáticamente las brechas. 


\section{CAPÍTULO V: CONCLUSIONES Y RECOMENDACIONES}

\subsection{Conclusiones de la investigación}

Después de un amplio análisis, tras el desarrollo de la investigación, se concluye lo siguiente:

1. Según nuestra hipótesis "Existen trabas no arancelarias para el ingreso de ropas de baño y bikinis a Francia”, se ha podido concluir, que no existen trabas, ni barreras arancelarias y/o no arancelarios que impidan el ingreso de ropas de baño y bikinis para damas al mercado francés, dado que el acuerdo comercial que el Perú tiene con la Unión Europea, permite la apertura a este gran mercado, siguiendo las normas de etiquetado, rotulado y las reglas de origen.

2. Según el objetivo general formulado, se concluye que los factores críticos de éxito que consolidan el posicionamiento comercial de la exportación de ropas de baño y bikinis desde Perú a Francia, son la formalidad empresarial, soporte financiero, capacidad de respuesta, calidad del producto, innovación, tecnología, marketing, distribución, productividad y metas o planes a futuro.

3. Se identificó las formas de entrada, políticas de comunicación y documentación necesaria para la exportación del producto, en donde se ha podido apreciar que existen diversos canales de comunicación y de distribución para el ingreso del producto al mercado francés, como, participación constante de ferias internacionales 
especializadas, la exportación directa e indirecta a través de un representante o distribuidor, $\mathrm{y}$, diferentes franquicias que se llegan a posicionar.

4. Del mismo modo, hemos podido concluir que las empresas que exportan ropas de baño y bikinis al mercado francés tienen ejecutado un plan innovación, ya que, los productos son fabricados acorde a las nuevas tendencias, y con la más alta calidad de sus materiales y maquinaria especializada. Las empresas están adaptadas a las herramientas tecnológicas del comercio, como son, las páginas web y redes sociales. Los canales de distribución y ventas se llevan a cabo a través de un representante comercial.

5. Finalmente, se concluye que la empresa es competitiva cuando todos los factores críticos de éxito se realizan con eficacia, cumpliendo los objetivos de la organización, superando a la competencia, brindando, un producto con excelencia de valor agregado a cualquier parte del mundo.

\subsection{Recomendaciones de la investigación}

a. Una de las recomendaciones que se ha podido determinar es, seguir creando valor continuo para la oferta exportable, la cual, será relevante para el logro de metas en el mercado exterior.

b. Realizar la reingeniería y reorganización de procesos, para eliminar cuellos de botella, dificultades en capacidad productiva, de negociación, cadena productiva y logística, de manera que, sea exitosa la relación y negociación comercial en el exterior. 
c. El Gobierno y las diferentes instituciones públicas y privadas avocadas a generar oportunidades comerciales internacionales están y seguirán realizando acuerdos, tratados, convenios, ferias internacionales, ruedas de negocios y misiones especializadas para la internacionalización de las empresas. Las empresas deben aprovechar las grandes oportunidades y tener la firme convicción a dónde quieren llegar para lograr una marca a nivel internacional.

d. Asimismo, que los países vecinos como Colombia, Brasil, Argentina y Uruguay tienen la industria textil más compacta y desarrollada que el Perú, por lo cual, tenemos que seguir el ejemplo de ellos para lograr el completo desarrollo del rubro textil.

e. Finalmente, se recomienda que las empresas no teman seguir el camino de la formalidad y la responsabilidad, que un plan de internacionalización conlleva. 


\section{REFERENCIAS}

1. AFP - Milenio (24 de abril de 2017). Exigen justicia a 4 años del peor accidente del mundo de la moda. Milenio. Recuperado de http://www.milenio.com/estilo/exigenjusticia-4-anos-accidente-mundo-moda [Consulta: 02 de febrero del 2018]

2. BBC. (18 de enero 2018). Agua Bendita, el secreto de los bikinis colombianos que están conquistando al mundo Recuperado de http://www.bbc.com/mundo/noticias$\underline{42725211}$ [Consulta: 02 de febrero del 2018]

3. Biasca, R. E., \& Paladino, M. (2006). Competitividad: transformar la fábrica para competir en el mundo (2a. ed.). Retrieved from https://ebookcentral.proquest.com

4. Charles Frederick Worth,( 1995). Diseño de modas. París.

5. CNN. ( 24 de Junio 2017). ¿Bikini para este verano? Así han cambiado los trajes de baño a lo largo de la historia. Recuperado de https://cnnespanol.cnn.com/2017/06/24/bikini-para-este-verano-asi-han-cambiadolos-trajes-de-bano-a-lo-largo-de-la-historia/

6. (Deloitte Development LLC.,2015). El futuro de la manufactura: fabricando cosas en un mundo cambiante, (15). Recuperado de https://www2.deloitte.com/content/dam/Deloitte/mx/Documents/manufacturing/Futur o-Manufactura-Espanol.pdf

7. Dinorah Salgado, Paula, \& Carpio, Jorge. (2017). Superexplotación, Informalidad y Precariedad: Reflexiones a partir del trabajo en la industria de la confección. Estudios del trabajo, (54), 55-89. Recuperado en 13 de mayo de 2018, de http://www.scielo.org.ar/scielo.php?script=sci_arttext\&pid=S2545$\underline{77562017000200003 \& \operatorname{lng}=\mathrm{es} \& \text { tlng=es }}$

8. Fondo Monetario Internacional. (2017, p. 2). Recuperado de http://www.imf.org/es/Publications/WEO/Issues/2017/09/19/world-economicoutlook-october-2017

9. Guerrero, D. G. (2014). Metodología de la investigación. Retrieved from https://ebookcentral.proquest.com

10. Guía de Negocios e Inversión Perú 2016-2017; 2016)

11. Guía Perú 2017, 2027) 
12. .Hernández Sampieri Roberto, Fernández Collado Carlos, Bapstista Lucio Pilar. (2014). Metodología de la Investigación. Mc Graw Hill, Sexta edición.

13. Instituto de Economía y Desarrollo Empresarial de la Cámara de Comercio de Lima. Revista CCL N ${ }^{a} 819$.

14. Johnson, Gerry y Scholes, Kevan (2002, p. 151). Exploring Corporate Strategy: Text and Cases. Financial Times Prentice Hall.

15. La teoría fundamentada: una metodología cualitativa. (2010). Retrieved from https://ebookcentral.proquest.com

16. Lieutier, A. (2010). Esclavos: los trabajadores costureros de la ciudad de Buenos Aires. Buenos Aires: Retórica Ediciones.

17. Lipovetsky, Gilles (2012) El Imperio de lo Efímero: La Moda y su Destino en las Sociedades Modernas, Anagrama, Barcelona.

18. López, G., y tan H. W.(Eds.). (2010). Evaluación de impacto de los programas para pyme Latinoamericana y el Caribe. Mexico D.F.: Banco Mundial.

19. Lusthaus Charles; Adrien Marie - Hélene; Andreson Gary; Can Fred y George Plinio Montalván(2002, p.200). Evaluación Organizacional: Marco para mejorar el desempeño. Banco Interamericano de Desarrollo. Centro internacional de investigaciones para el desarrollo Otawa - Canadá.

20. Lynch, (2003:102). Corporate Strategy. Prentice Hall. London.

21. Montero, J. (2011). Neoliberal fashion: The political economy of sweats-

22. hops in Europe and Latin America. Durham theses, Durham University.

23. Pesok M.J.C., 2012. Introducción a la tecnología textil. Recuperado de https://ebookcentral.proquest.com

24. Mincetur. Procolombia - Maison du pret a porter, 2013.

25. Mincetur. (diciembre del 2017 )PROCOLOMBIA (2013)

26. Promperú, (2014). Recuperado de http://www.siicex.gob.pe/siicex/resources/sectoresproductivos/Francia.pdf

27. PROMPERU. Recuperado de Guía Mercado Francia industria de la Moda y Decoración - Promperu 
28. Promperú, (2017). Recuperado de http://repositorio.promperu.gob.pe/repositorio/bitstream/handle/123456789/2402/Perf il_logístico_Francia_sector_vestimenta_2017_keyword_principal.pdf?sequence $=1 \&$ is Allowed $=\mathrm{y}$

29. Rockart, John F, (1979, pp.8). Chief executives define their own data needs. Harvard Business Review 57: 81-92.

30. Saavedra García, M.-L. (2012). Una propuesta para la determinación de la competitividad en la pyme latinoamericana. Pensamiento y Gestión, 33, 93-124.

31. Superintendencia Nacional De Administración Tributaria. Recuperado de http://www.aduanet.gob.pe/cl-ad-itestadispartida/resumenPPaisS01Alias

32. Textilfy. Recuperado de https://textilfy.es/nuestras-telas/punto-de-lycra/ [4 de enero 2018].

33. Underhill, P. (2000). Porqué compramos. Gestión._Universidad Autónoma de Aguas Calientes, (2010)

34. Writing Alexis, España 2007. Confección de Trajes de baño. España. 


\section{$\underline{\text { ANEXOS }}$}

\section{ANEXO 1:}

Lista de importadores para el producto seleccionado: Producto: 611241 Bañadores de punto, de fibras sintéticas, para mujeres o niñas.

Unidad : Dólar Americano miles

\begin{tabular}{|c|c|c|c|c|c|}
\hline Importadores & $\begin{array}{c}\text { valor } \\
\text { importada } \\
\text { en } 2013\end{array}$ & $\begin{array}{c}\text { valor } \\
\text { importada } \\
\text { en } 2014\end{array}$ & $\begin{array}{c}\text { valor } \\
\text { importada } \\
\text { en } 2015\end{array}$ & $\begin{array}{c}\text { valor } \\
\text { importada } \\
\text { en } 2016\end{array}$ & $\begin{array}{c}\text { valor } \\
\text { importada } \\
\text { en } 2017\end{array}$ \\
\hline Mundo & 2.840 .810 & 2.996 .725 & 2.962 .498 & 2.933 .493 & \\
\hline $\begin{array}{c}\text { Estados Unidos de } \\
\text { América }\end{array}$ & 819.896 & 851.849 & 903.634 & 860.021 & 916.533 \\
\hline Hong Kong, China & 277.828 & 265.883 & 282.845 & 251.427 & 242.047 \\
\hline Alemania & 222.729 & 232.675 & 223.469 & 229.774 & 256.304 \\
\hline Francia & 160.003 & 180.931 & 167.576 & 186.033 & 201.604 \\
\hline Reino Unido & 169.533 & 198.076 & 200.119 & 180.032 & 181.073 \\
\hline España & 99.993 & 115.039 & 114.268 & 115.698 & 119.880 \\
\hline Italia & 111.336 & 116.457 & 107.510 & 100.805 & 111.457 \\
\hline Países Bajos & 69.339 & 80.796 & 80.119 & 88.591 & 112.632 \\
\hline Canadá & 96.715 & 94.071 & 91.438 & 85.553 & 99.437 \\
\hline Suiza & 73.870 & 78.283 & 79.730 & 81.945 & 99.068 \\
\hline Australia & 60.106 & 57.087 & 66.720 & 64.781 & 73.175 \\
\hline Japón & 62.955 & 67.456 & 61.643 & 64.567 & 59.006 \\
\hline
\end{tabular}




\begin{tabular}{|c|c|c|c|c|c|}
\hline Bélgica & 67.875 & 73.303 & 47.407 & 57.156 & 54.642 \\
\hline Austria & 57.558 & 54.577 & 48.941 & 50.924 & 55.593 \\
\hline Polonia & 41.337 & 40.223 & 41.391 & 49.034 & 64.136 \\
\hline Rusia, Federación de & 63.911 & 65.222 & 41.472 & 38.216 & 47.391 \\
\hline México & 26.128 & 27.927 & 30.599 & 28.549 & 33.231 \\
\hline Croacia & 8.490 & 29.923 & 29.947 & 27.034 & 31.871 \\
\hline Suecia & 24.226 & 22.131 & 24.230 & 23.775 & 28.122 \\
\hline Chile & 17.369 & 17.195 & 16.463 & 23.007 & 18.358 \\
\hline Turquía & 16.145 & 17.716 & 17.616 & 22.028 & 20.027 \\
\hline Portugal & 15.605 & 15.702 & 14.332 & 19.939 & 21.255 \\
\hline Corea, República de & 11.967 & 12.409 & 14.656 & 16.800 & 20.198 \\
\hline Dinamarca & 14.960 & 14.630 & 14.927 & 15.419 & 14.885 \\
\hline República Checa & 15.719 & 19.392 & 15.253 & 15.123 & 18.074 \\
\hline Grecia & 21.455 & 20.447 & 14.918 & 15.113 & 19.921 \\
\hline Emiratos Árabes Unidos & 18.273 & 21.192 & 16.692 & 14.958 & \\
\hline Noruega & 15.308 & 16.148 & 14.359 & 12.720 & 15.179 \\
\hline Irlanda & 10.647 & 12.285 & 12.584 & 11.985 & 13.274 \\
\hline Hungría & 9.480 & 10.945 & 10.312 & 11.760 & 12.682 \\
\hline Eslovaquia & 11.407 & 11.480 & 11.129 & 11.541 & 12.508 \\
\hline Israel & 12.014 & 13.041 & 10.946 & 10.910 & 13.523 \\
\hline Finlandia & 11.431 & 9.748 & 8.637 & 9.104 & 8.999 \\
\hline Nueva Zelandia & 8.801 & 8.486 & 7.750 & 7.856 & 6.954 \\
\hline Ucrania & 8.564 & 4.807 & 2.345 & 7.739 & \\
\hline
\end{tabular}




\begin{tabular}{|c|c|c|c|c|c|}
\hline Singapur & 6.224 & 4.080 & 4.146 & 7.293 & 8.008 \\
\hline Brasil & 6.895 & 8.452 & 11.551 & 7.260 & 10.049 \\
\hline Lituania & 4.468 & 5.258 & 6.434 & 6.379 & 6.940 \\
\hline Sudafrica & 4.451 & 4.615 & 3.941 & 6.179 & 7.119 \\
\hline Eslovenia & 5.303 & 5.585 & 4.888 & 5.675 & 6.078 \\
\hline Rumania & 4.046 & 4.507 & 4.200 & 5.669 & 6.714 \\
\hline China & 5.066 & 4.025 & 5.709 & 5.462 & \\
\hline Perú & 4.717 & 5.189 & 3.827 & 4.011 & \\
\hline Viet Nam & 37 & 22 & 222 & 3.888 & \\
\hline Tailandia & 2.857 & 3.496 & 3.711 & 3.740 & 4.977 \\
\hline Líbano & 3.666 & 3.777 & 3.344 & 3.673 & \\
\hline Serbia & 2.534 & 4.160 & 5.550 & 3.476 & 2.051 \\
\hline Uruguay & 2.989 & 2.624 & 2.664 & 3.437 & 3.610 \\
\hline Kuwait & 0 & 3.289 & 3.191 & 3.250 & \\
\hline Taipei Chino & 2.252 & 2.560 & 2.920 & 2.760 & 2.720 \\
\hline Costa Rica & 2.128 & 2.097 & 1.497 & 2.684 & \\
\hline Estonia & 4.413 & 5.246 & 3.779 & 2.617 & 1.916 \\
\hline Bulgaria & 2.332 & 2.872 & 1.923 & 2.540 & 3.672 \\
\hline Malasia & 1.041 & 1.064 & 1.954 & 2.509 & 2.609 \\
\hline Belarús & 1.211 & 1.640 & 1.614 & 2.218 & \\
\hline Letonia & 4.615 & 3.540 & 2.237 & 2.177 & 2.256 \\
\hline Indonesia & 1.885 & 1.994 & 2.111 & 1.981 & \\
\hline Chipre & 2.131 & 2.637 & 1.610 & 1.925 & 2.253 \\
\hline
\end{tabular}




\begin{tabular}{|c|c|c|c|c|c|}
\hline Argentina & 781 & 850 & 664 & 1.811 & 2.620 \\
\hline India & 828 & 913 & 1.030 & 1.734 & 1.990 \\
\hline Panamá & 1.319 & 1.097 & 1.558 & 1.445 & \\
\hline
\end{tabular}

\section{ANEXO 2:}

Lista de los mercados proveedores para un producto importado por Francia

\section{Unidad : miles Dólar Americano}

\begin{tabular}{|c|c|c|c|}
\hline Exportadores & $\begin{array}{c}\text { Valor importada } \\
\text { en } 2015\end{array}$ & $\begin{array}{c}\text { Valor importada } \\
\text { en } 2016\end{array}$ & $\begin{array}{c}\text { Valor importada } \\
\text { en } 2017\end{array}$ \\
\hline Mundo & 167.576 & 186.033 & 201.604 \\
\hline China & 72.367 & 83.680 & 85.893 \\
\hline Túnez & 32.759 & 35.701 & 45.739 \\
\hline Viet Nam & 4.058 & 7.543 & 12.474 \\
\hline Sri Lanka & 10.860 & 9.486 & 9.699 \\
\hline Italia & 5.177 & 5.633 & 4.884 \\
\hline Albania & 4.025 & 4.595 & 4.877 \\
\hline Camboya & 1.181 & 4.189 & 4.853 \\
\hline Francia & 2.700 & 12 & 3.691 \\
\hline Bulgaria & 3.371 & 4.335 & 3.074 \\
\hline Bangladesh & 1.988 & 2.095 & 3.037 \\
\hline Bélgica & 2.467 & 1.812 & 2.064 \\
\hline Alemania & 8.131 & 2.430 & 1.844 \\
\hline
\end{tabular}




\begin{tabular}{|c|c|c|c|}
\hline Marruecos & 1.053 & 1.413 & 1.706 \\
\hline $\begin{array}{c}\text { Estados Unidos de } \\
\text { América }\end{array}$ & 1.352 & 4.731 & 1.690 \\
\hline Myanmar & 145 & 303 & 1.417 \\
\hline España & 1.509 & 1.579 & 1.296 \\
\hline Turquía & 979 & 778 & 1.156 \\
\hline Bosnia y Herzegovina & 451 & 551 & 1.127 \\
\hline Reino Unido & 1.890 & 1.635 & 1.121 \\
\hline Croacia & 799 & 849 & 864 \\
\hline Hong Kong, China & 636 & 727 & 836 \\
\hline Indonesia & 521 & 684 & 834 \\
\hline Austria & 776 & 745 & 753 \\
\hline Brasil & 1.583 & 841 & 719 \\
\hline Países Bajos & 903 & 988 & 671 \\
\hline Madagascar & 173 & 82 & 623 \\
\hline Serbia & 583 & 492 & 615 \\
\hline Eslovaquia & 163 & 535 & 561 \\
\hline Mauricio & 1.095 & 870 & 394 \\
\hline Grecia & 666 & 993 & 348 \\
\hline Colombia & 420 & 224 & 334 \\
\hline Zona Nep & 215 & 3.388 & 300 \\
\hline India & 173 & 351 & 269 \\
\hline Rumania & 151 & 68 & 255 \\
\hline
\end{tabular}




\begin{tabular}{|c|c|c|c|}
\hline Canadá & 224 & 209 & 212 \\
\hline Portugal & 145 & 261 & 180 \\
\hline Polonia & 34 & 251 & 175 \\
\hline Ucrania & 151 & 89 & 173 \\
\hline Tailandia & 100 & 130 & 98 \\
\hline Malasia & 21 & 9 & 86 \\
\hline México & 11 & 59 & 73 \\
\hline Taipei Chino & 99 & 9 & 67 \\
\hline Eslovenia & 22 & 40 & 63 \\
\hline Hungría & 81 & 33 & 59 \\
\hline Australia & 49 & 39 & 49 \\
\hline Suiza & 61 & 153 & 48 \\
\hline República Dominicana & 0 & 8 & 45 \\
\hline $\begin{array}{c}\text { Venezuela, República } \\
\text { Bolivariana de }\end{array}$ & 0 & 29 & 45 \\
\hline Moldova, República de & 2 & 132 & 38 \\
\hline Dinamarca & 0 & 9 & 32 \\
\hline Corea, República de & 4 & 1 & 25 \\
\hline Perú & 18 & 22 & 20 \\
\hline República Checa & 31 & 35 & 14 \\
\hline Lituania & 0 & 0 & 14 \\
\hline Estonia & 12 & 8 & 10 \\
\hline Sudafrica & 57 & 5 & 9 \\
\hline
\end{tabular}




\begin{tabular}{|c|c|c|c|}
\hline Israel & 11 & 18 & 6 \\
\hline Suriname & 0 & 0 & 6 \\
\hline Suecia & 13 & 8 & 5 \\
\hline Japón & 1 & 3 & 4 \\
\hline Filipinas & 3 & 2 & 4 \\
\hline Egipto & 2 & 1 & 4 \\
\hline Pakistán & 0 & 20 & 3 \\
\hline Niué & 0 & 0 & 2 \\
\hline Emiratos Árabes Unidos & 0 & 0 & 2 \\
\hline Honduras & 0 & 0 & 2 \\
\hline Letonia & 1 & 2 & 2 \\
\hline Luxemburgo & 1 & 0 & 2 \\
\hline Singapur & 37 & 1 & 2 \\
\hline Chile & 1 & 1 & 1 \\
\hline Guatemala & 0 & 0 & 1 \\
\hline Noruega & 0 & 0 & 1 \\
\hline Saint Kitts y Nevis & 0 & 0 & 1 \\
\hline Sierra Leona & 0 & 0 & 1 \\
\hline $\begin{array}{l}\text { Tierras Australes y } \\
\text { Antárticas Francesas }\end{array}$ & 0 & 1 & 0 \\
\hline $\begin{array}{c}\text { Lao, República } \\
\text { Democrática Popular }\end{array}$ & 31 & 0 & 0 \\
\hline $\begin{array}{l}\text { Estados Unidos Minor } \\
\text { periferico Islas }\end{array}$ & 1 & 3 & 0 \\
\hline
\end{tabular}




\begin{tabular}{|c|c|c|c|}
\hline Argelia & 0 & 0 & 0 \\
\hline Bahrein & 0 & 0 & 0 \\
\hline Barbados & 0 & 0 & 0 \\
\hline Belarús & 0 & 0 & 0 \\
\hline Chipre & 0 & 0 & 0 \\
\hline Polinesia Francesa & 2 & 0 & 0 \\
\hline Georgia & 0 & 0 & 0 \\
\hline Irlanda & 1.026 & 0 & 0 \\
\hline Côte d'Ivoire & 0 & 0 & 0 \\
\hline Jordania & 0 & 0 & 0 \\
\hline Kuwait & 0 & 0 & 0 \\
\hline Líbano & 0 & 0 & 0 \\
\hline Macao, China & 0 & 0 & 0 \\
\hline Nueva Caledonia & 0 & 0 & 0 \\
\hline Nueva Zelandia & 1 & 0 & 0 \\
\hline Qatar & 0 & 0 & 0 \\
\hline Rusia, Federación de & 0 & 0 & 0 \\
\hline Uruguay & 0 & 0 & 0 \\
\hline
\end{tabular}


ANEXO 3:

Lista de los mercados importadores para un producto exportado por Perú

Unidad : miles Dólar Americano

\begin{tabular}{|c|c|c|c|c|c|}
\hline Importadores & $\begin{array}{c}\text { Valor } \\
\text { exportada } \\
\text { en } 2012\end{array}$ & $\begin{array}{c}\text { Valor } \\
\text { exportada } \\
\text { en } 2013\end{array}$ & $\begin{array}{c}\text { Valor } \\
\text { exportada } \\
\text { en } 2014\end{array}$ & $\begin{array}{c}\text { Valor } \\
\text { exportada } \\
\text { en } 2015\end{array}$ & $\begin{array}{c}\text { Valor } \\
\text { exportada } \\
\text { en } 2016\end{array}$ \\
\hline Mundo & 3.152 & 950 & 489 & 387 & 425 \\
\hline $\begin{array}{c}\text { Estados Unidos de } \\
\text { América }\end{array}$ & 168 & 147 & 128 & 167 & 147 \\
\hline Chile & 70 & 192 & 44 & 17 & 61 \\
\hline Francia & 0 & 0 & 35 & 35 & 39 \\
\hline Panamá & 9 & 4 & 0 & 12 & 38 \\
\hline Argentina & 0 & 1 & 0 & 0 & 37 \\
\hline Australia & 5 & 0 & 0 & 23 & 35 \\
\hline Reino Unido & 98 & 66 & 40 & 41 & 18 \\
\hline Curaçao & 5 & 5 & 11 & 2 & 11 \\
\hline Líbano & 0 & 23 & 16 & 14 & 10 \\
\hline República Dominicana & 637 & 3 & 4 & 6 & 9 \\
\hline Corea, República de & 0 & 0 & 0 & 0 & 6 \\
\hline Costa Rica & 251 & 2 & 4 & 6 & 3 \\
\hline Ecuador & 20 & 14 & 46 & 16 & 3 \\
\hline México & 43 & 26 & 11 & 4 & 3 \\
\hline España & 36 & 27 & 4 & 0 & 2 \\
\hline
\end{tabular}




\begin{tabular}{|c|c|c|c|c|c|}
\hline $\begin{array}{c}\text { Venezuela, República } \\
\text { Bolivariana de }\end{array}$ & 1.741 & 359 & 135 & 39 & 1 \\
\hline Emiratos Árabes Unidos & 12 & 4 & 7 & 0 & 0 \\
\hline Bélgica & 0 & 15 & 0 & 0 & 0 \\
\hline $\begin{array}{l}\text { Bolivia, Estado } \\
\text { Plurinacional de }\end{array}$ & 7 & 6 & 0 & 0 & 0 \\
\hline Brasil & 1 & 0 & 0 & 0 & 0 \\
\hline Colombia & 0 & 6 & 0 & 0 & 0 \\
\hline Cuba & 7 & 1 & 0 & 0 & 0 \\
\hline El Salvador & 0 & 4 & 0 & 0 & 0 \\
\hline Finlandia & 0 & 4 & 5 & 0 & 0 \\
\hline Hong Kong, China & 2 & 0 & 0 & 0 & 0 \\
\hline Israel & 0 & 7 & 0 & 0 & 0 \\
\hline Italia & 0 & 0 & 0 & 0 & 0 \\
\hline Japón & 10 & 16 & 0 & 0 & 0 \\
\hline Kuwait & 2 & 0 & 0 & 0 & 0 \\
\hline Malta & 0 & 7 & 0 & 0 & 0 \\
\hline Países Bajos & 0 & 5 & 0 & 5 & 0 \\
\hline Sudafrica & 25 & 3 & 0 & 0 & 0 \\
\hline
\end{tabular}


ANEXO 4:

\section{Matriz de Consistencia}

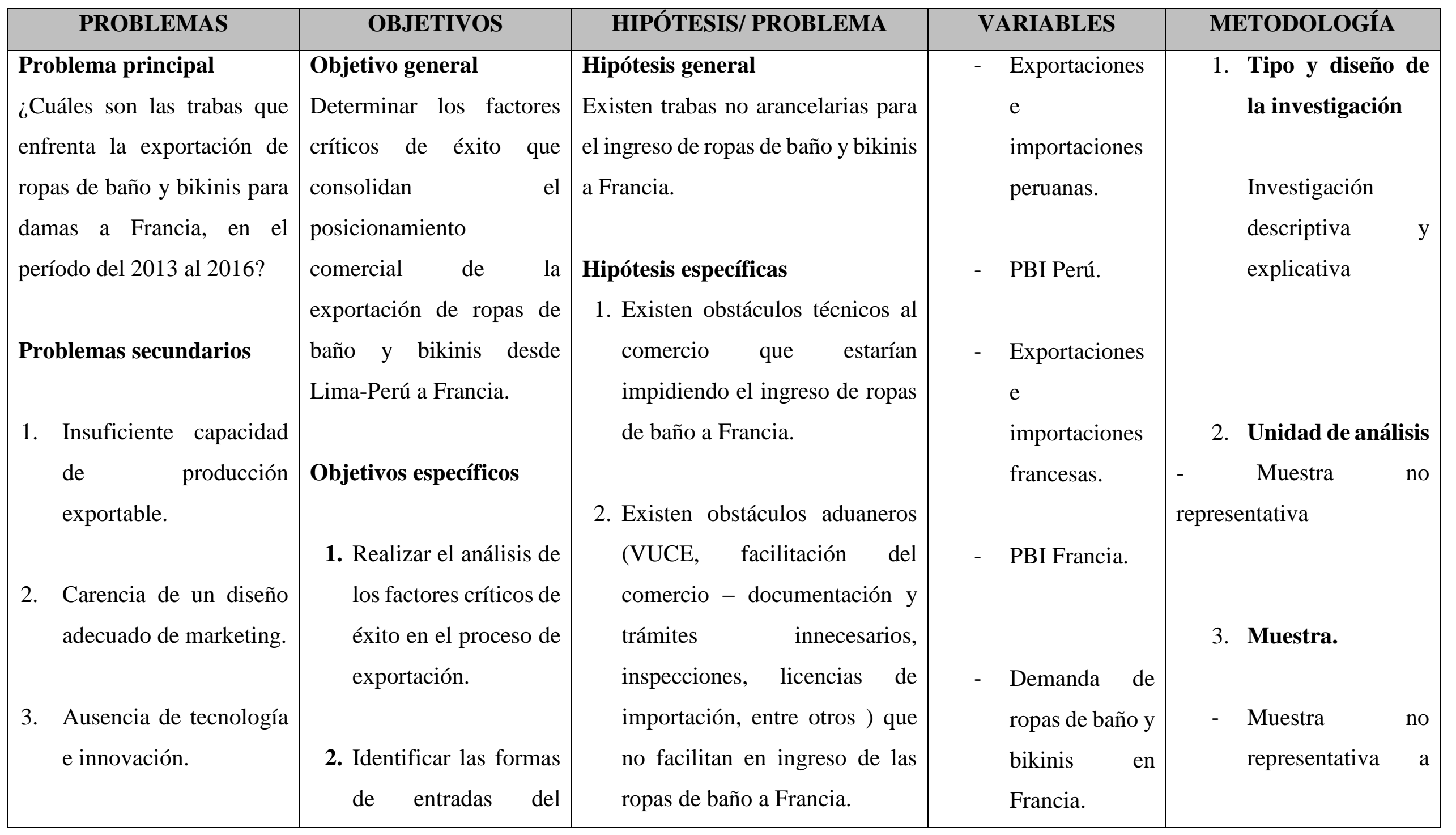




\begin{tabular}{|c|c|c|c|c|}
\hline $\begin{array}{l}\text { 4. Falta de mano de obra } \\
\text { calificada. } \\
\text { 5. Adecuada } \\
\text { implementación de } \\
\text { canales de venta y } \\
\text { distribución. }\end{array}$ & 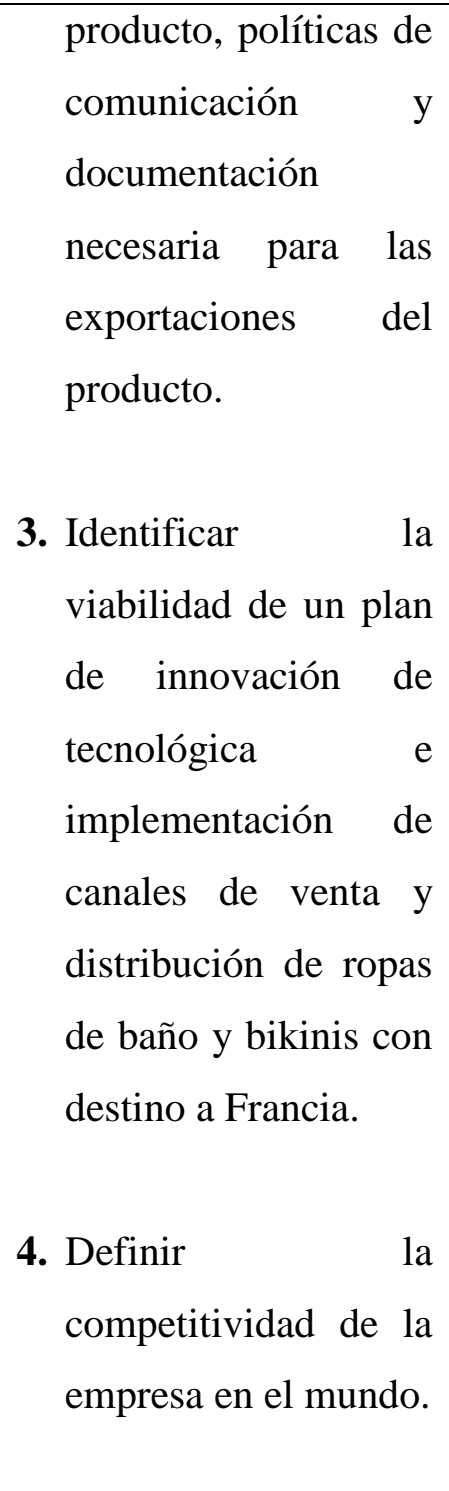 & $\begin{array}{l}\text { 3. La ausencia de conocimiento } \\
\text { de las ventajas del TLC Unión } \\
\text { Europea en materia de reglas de } \\
\text { origen para la exportación de } \\
\text { ropas de baño y bikinis de } \\
\text { damas. } \\
\text { 4. La carencia de un adecuado } \\
\text { diseño marketing } \\
\text { internacional es un factor } \\
\text { determinante para el } \\
\text { posicionamiento comercial de } \\
\text { la exportación de ropas de baño } \\
\text { y bikinis a Francia. } \\
\text { 5. La ausencia de tecnología e } \\
\text { innovación para los } \\
\text { exportadores de ropas de baño } \\
\text { y bikinis a Francia afecta la } \\
\text { competitividad del producto. }\end{array}$ & - & $\begin{array}{l}\text { través de } \\
\text { entrevistas a: } \\
\text { Gerentes del sector } \\
\text { textil peruano del } \\
\text { rubro bikinis. } \\
\text { Funcionarios del } \\
\text { sector aduanero. } \\
\text { Importadores del } \\
\text { sector textil } \\
\text { francés. }\end{array}$ \\
\hline
\end{tabular}




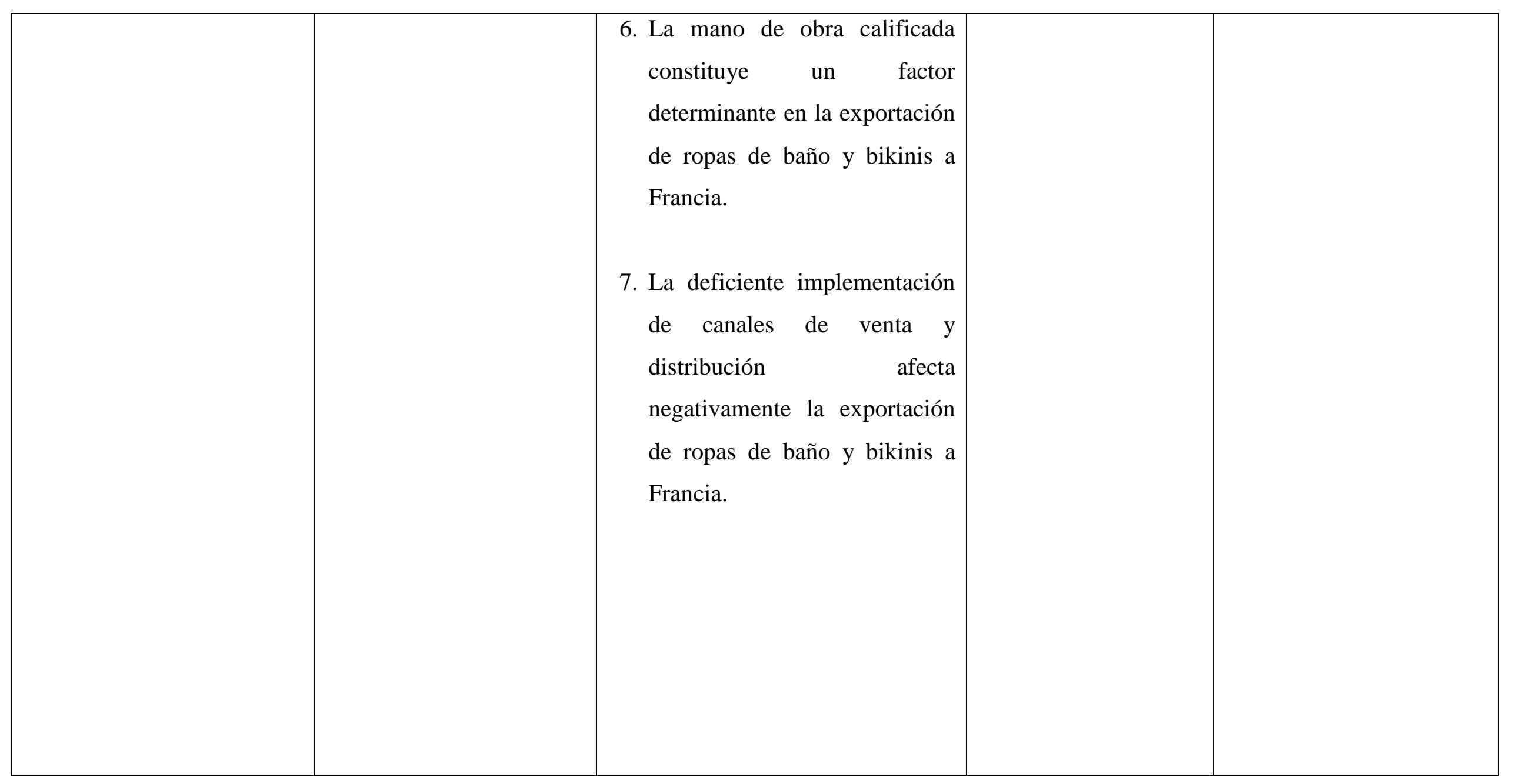




\section{Categoría - Segmento: Preguntas}

\begin{tabular}{|c|c|c|c|}
\hline $\begin{array}{l}\text { CATEGORIAS / } \\
\text { SEGMENTOS }\end{array}$ & S1: Sector Instituciones Públicas & S2: Sector Exportador & S3: Importador \\
\hline \multirow{4}{*}{$\begin{array}{l}\text { Categoría 1: } \\
\text { Capacidad productiva y } \\
\text { Ventajas competitivas de } \\
\text { la oferta exportable de } \\
\text { ropas de baño y bikinis } \\
\text { para damas. }\end{array}$} & $\begin{array}{c}\text { Preg 1: } \\
\text { ¿Cúales son las características y } \\
\text { ventajas del mercado francés que } \\
\text { lo dierencian de otros mercados en } \\
\text { la exportación de ropas de baño y } \\
\text { bikinis? }\end{array}$ & $\begin{array}{c}\text { Preg 1: } \\
\text { ¿Cúales son las características y } \\
\text { ventajas del mercado francés que lo } \\
\text { dierencian de otros mercados en la } \\
\text { exportación de ropas de baño y } \\
\text { bikinis? }\end{array}$ & $\begin{array}{c}\text { Preg 1: } \\
\text { ¿Cúales son las características } \\
\text { y ventajas del mercado francés } \\
\text { que lo diferencian de otros } \\
\text { mercados en la importación de } \\
\text { ropas de baño y bikinis? }\end{array}$ \\
\hline & $\begin{array}{c}\text { Preg 2: } \\
\text { ¿Hay suficiente capacidad } \\
\text { productiva en las empresas } \\
\text { peruanas en la exportación de } \\
\text { ropas de baño y bikinis al mercado } \\
\text { francés? }\end{array}$ & $\begin{array}{c}\text { Preg 2: } \\
\text { ¿Hay suficiente capacidad } \\
\text { productiva en las empresas } \\
\text { peruanas en la exportación de ropas } \\
\text { de baño y bikinis al mercado } \\
\text { francés? }\end{array}$ & $\begin{array}{c}\text { Preg 2: } \\
\text { ¿Hay suficiente capacidad } \\
\text { productiva en las empresas } \\
\text { peruanas en la exportación de } \\
\text { ropas de baño y bikinis al } \\
\text { mercado francés? }\end{array}$ \\
\hline & $\begin{array}{l}\text { Preg 3: ¿Perú está en el mismo } \\
\text { nivel que Colombia o Brasil en el } \\
\text { rubro de ropas de baño y bikinis o } \\
\text { de qué manera podría mejorar? }\end{array}$ & $\begin{array}{l}\text { Preg 3: ¿Perú está en el mismo nivel } \\
\text { que Colombia o Brasil en el rubro de } \\
\text { ropas de baño y bikinis o de qué } \\
\text { manera podría mejorar? }\end{array}$ & $\begin{array}{c}\text { Preg 3: ¿Perú está en el mismo } \\
\text { nivel que Colombia o Brasil en } \\
\text { el rubro de ropas de baño y } \\
\text { bikinis o de qué manera podría } \\
\text { mejorar? }\end{array}$ \\
\hline & $\begin{array}{c}\text { Preg 4: } \\
\text { ¿Qué ventajas competitivas } \\
\text { encuentra en los exportadores } \\
\text { peruanos en comparación con los } \\
\text { exportadores de otros países? }\end{array}$ & $\begin{array}{c}\text { Preg 4: } \\
\text { ¿Qué ventajas competitivas } \\
\text { encuentra en los exportadores } \\
\text { peruanos en comparación con los } \\
\text { exportadores de otros países? }\end{array}$ & $\begin{array}{c}\text { Preg 4: } \\
\text { ¿Qué ventajas competitivas } \\
\text { encuentra en los exportadores } \\
\text { peruanos en comparación con } \\
\text { los exportadores de otros } \\
\text { países? }\end{array}$ \\
\hline \multirow{2}{*}{$\begin{array}{c}\text { Categoría 2: } \\
\text { Barreras arancelarias y } \\
\text { Proceso Logístico de la } \\
\text { oferta exportable de } \\
\text { ropas de baño y bikinis } \\
\text { para damas. }\end{array}$} & $\begin{array}{c}\text { Preg 5: } \\
\text { ¿Qué barreras no arancelarias y } \\
\text { obstáculos técnicos existen en el } \\
\text { proceso de exportación de ropas } \\
\text { de baño y bikinis para damas? } \\
\text { ¿Alguna vez se presentó alguna } \\
\text { dificultad en el proceso de } \\
\text { exportación? }\end{array}$ & $\begin{array}{c}\text { Preg 5: } \\
\text { ¿Qué barreras no arancelarias y } \\
\text { obstáculos técnicos existen en el } \\
\text { proceso de exportación de ropas de } \\
\text { baño y bikinis para damas? ¿Alguna } \\
\text { vez tuvo alguna dificultad en el } \\
\text { proceso de exportación? }\end{array}$ & $\begin{array}{c}\text { Preg 5: } \\
\text { ¿Qué barreras no arancelarias } \\
\text { y obstáculos técnicos existen } \\
\text { en el proceso de importación } \\
\text { de ropas de baño y bikinis para } \\
\text { damas? ¿Alguna vez tuvo } \\
\text { alguna dificultad en el proceso } \\
\text { de importación? }\end{array}$ \\
\hline & $\begin{array}{c}\text { Preg 6: } \\
\text { ¿Cómo se podría mejorar el } \\
\text { proceso logístico en la exportación } \\
\text { de ropas y bikinis a Francia? ¿Por } \\
\text { qué el transporte aéreo tiene } \\
\text { mayor porcentaje en la exportación } \\
\text { de ropas de baño y bikinis para } \\
\text { damas a Francia? }\end{array}$ & $\begin{array}{c}\text { Preg 6: } \\
\text { ¿Cómo se podría mejorar el proceso } \\
\text { logístico en la exportación de ropas } \\
\text { y bikinis a Francia? ¿Por qué el } \\
\text { transporte aéreo tiene mayor } \\
\text { porcentaje en la exportación de } \\
\text { ropas de baño y bikinis para damas } \\
\text { a Francia? }\end{array}$ & $\begin{array}{l}\text { Preg 6: ¿Cómo se podría } \\
\text { mejorar el proceso logístico en } \\
\text { la exportación de ropas y } \\
\text { bikinis a Francia? ¿Por qué el } \\
\text { transporte aéreo tiene mayor } \\
\text { porcentaje en la exportación de } \\
\text { ropas de baño y bikinis para } \\
\text { damas a Francia? }\end{array}$ \\
\hline
\end{tabular}




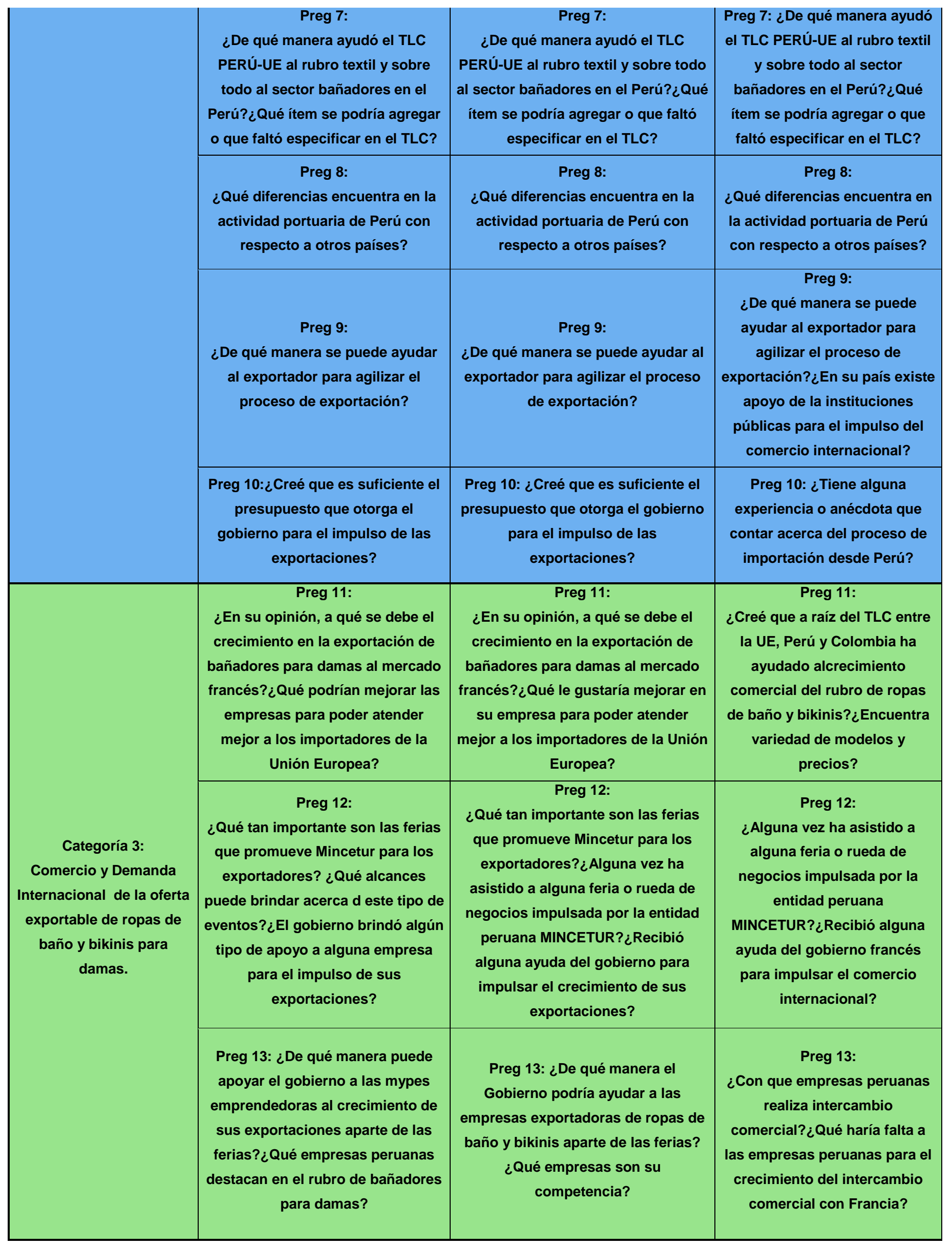




\section{ANEXO 6:}

\section{Matriz General}

\begin{tabular}{|c|c|c|c|c|c|}
\hline $\begin{array}{l}\text { Categorias/ } \\
\text { Entrevistados }\end{array}$ & Preguntas & Segmento 1: Instituciones públicas & Segmento 2: Exportador & Segmento 3: Importador & Conclusión \\
\hline \multirow{3}{*}{$\begin{array}{l}\text { Categoria 1: } \\
\text { Capacidad } \\
\text { productiva y } \\
\text { Ventajas } \\
\text { competitivas }\end{array}$} & Preg 1 & $\begin{array}{l}\text { Francia es un mercado competitivo, exigente, de buen } \\
\text { vestir y con las últimas tendencias. Los importadores } \\
\text { franceses establecen acuerdos comerciales de manera } \\
\text { formal, responsable en los plazos, pagos y el } \\
\text { cumplimiento de la negociación. El Perú está calificado } \\
\text { como outsourcing de las empresas extranjeras, } \\
\text { fabricando para ellas pero no con una marca propia, son } \\
\text { pocas las empresas que invierten en desarrollar una } \\
\text { marca en el exterior. }\end{array}$ & $\begin{array}{l}\text { No hay una característica específica, los exportadores } \\
\text { ofrecen todas las colecciones al mundo, las prendas } \\
\text { son de calidad y es lo que el mercado requiere. Se } \\
\text { necesita que la marca sea conocida para tener } \\
\text { continuidad en el comercio. }\end{array}$ & $\begin{array}{l}\text { En el verano que abarca de junio a agosto el comercio } \\
\text { aumenta del lado del mar, las tiendas también } \\
\text { funcionan en abril y mayo. El mercado de trajes de } \\
\text { baño debe ser más productivo en estos meses de } \\
\text { verano. En el resto de meses hay muchísimas tiendas } \\
\text { en los grandes almacenes como Galeries Lafayette o } \\
\text { Printemps o Le Bon Marché. Además hay otros } \\
\text { territorios donde venden de diciembre a marzo. }\end{array}$ & $\begin{array}{l}\text { Se necesita tener la formalidad y responsabilidad } \\
\text { pertinente para cumplir la negociación con un } \\
\text { importador francés, generando continuidad en el } \\
\text { negocio. Se debe invertir en imagen de la marca para } \\
\text { obtener mayores ganancias en el comercio } \\
\text { exterior.Los mese de verano deben ser más } \\
\text { productivos que otros meses. }\end{array}$ \\
\hline & Preg 2 & $\begin{array}{l}\text { Hasta el momento vienen respondiendo al comercio de } \\
\text { bañadores y de eso se muestra en las estadísticas y es un } \\
\text { rubro en crecimiento. }\end{array}$ & $\begin{array}{l}\text { Es un sector que está en crecimiento, se envían } \\
\text { bañadores a todas partes del mundo. Hay capacidad } \\
\text { productiva, pero hay ciertos momentos donde se } \\
\text { presentan cuellos de botella en el mercado interno } \\
\text { pero eso no impide el cumplimiento con el mercado } \\
\text { exterior. }\end{array}$ & Sólo conoce a Aguaclara, no sabe de otras marcas. & $\begin{array}{l}\text { Si los procesos están bien definidos y organizados la } \\
\text { empresa no tendrá cuellos de botella y no afectará la } \\
\text { capacidad productiva de la empresa. Sólo trabaja con } \\
\text { Aguaclara y tiene capacidad productiva en cualquier } \\
\text { época del año, no sabe de otras marcas. }\end{array}$ \\
\hline & Preg 3 & $\begin{array}{l}\text { Brasil, Colombia y Chile tienen mayor desarrollo en el } \\
\text { rubro por la alta tecnología que emplean, realización de } \\
\text { ferias de proveedores y el gran apoyo de sus gobiernos } \\
\text { para el éxito del comercio exterior. Brasil y Colombia han } \\
\text { desarrollado de manera compacta el rubro textil gracias } \\
\text { a las sinergias de los entes, a la organización de las } \\
\text { cadenas productivas y creando tendencias para el } \\
\text { mundo han logrado el reconocido lugar en el cual se } \\
\text { encuentran. Las amplias estaciones veraniegas y lugares } \\
\text { turísticos cercanos en el Caribe y el Pacífico confluyen } \\
\text { para el crecimiento comercial del rubro bañadores. }\end{array}$ & $\begin{array}{l}\text { En el negocio de bañadores Brasil es el más avanzado } \\
\text { seguido de Colombia y Argentina que ocupan el } \\
\text { segundo lugar, en el tercer se encuentra Uruguay, el } \\
\text { cuarto lugar lo ocupa Perú y Paraguay. Si una empresa } \\
\text { tiene un plan de crecimiento entonces debe exportar, } \\
\text { porque no lo logrará si sólo realiza actividades en el } \\
\text { mercado interno. Los empresarios deben organizarze } \\
\text { de tal manera que cree una sinergia con sus } \\
\text { proveedores, importadores, colaboradores, gremios e } \\
\text { instituciones públicas. }\end{array}$ & $\begin{array}{l}\text { Países como Brasil o Colombia, tienen muchas marcas } \\
\text { que llegan a Francia con mucha organización, con } \\
\text { precios competitivos, conocen el mercado francés y } \\
\text { algunas veces tienen precios altos. Desde hace } 10 \\
\text { años Brasil y Colombia llegan a Francia y presentan } \\
\text { nuevas marcas cada año. Sarl Bega en el } 2006 \text { fue } \\
\text { unos de los primeros sitios web que comenzó con } \\
\text { Pokopano y Compañia Marítima(marcas brasileñas) en } \\
\text { Francia. }\end{array}$ & $\begin{array}{l}\text { Se debe crear sinergia con los proveedores, } \\
\text { importadores, colaboradores, gremios y entidades } \\
\text { públicas. Desarrollar tendencias potenciando la } \\
\text { marca, innovando, implementando tecnología, ser } \\
\text { partícipe activo de ferias internacionales para } \\
\text { alcanzar a los grandes como Brasil, Colombia, } \\
\text { Argentina y Uruguay, ya que se logrará el crecimiento } \\
\text { constante sólo en el mercado externo. Tanto Brasil } \\
\text { como Colombia tienen muchas marcas que llegan a } \\
\text { Francia con buena organización, precios competitivos } \\
\text { y conocen muy bien el mercado francés, desde hace } \\
10 \text { años cada año presentan nuevas marcas. Sarl }\end{array}$ \\
\hline
\end{tabular}




\begin{tabular}{|c|c|c|c|c|c|}
\hline & & & & & $\begin{array}{l}\text { Bega en el } 2006 \text { inició con las marcas Pokopano y } \\
\text { Compañia marítima en su sitio web. }\end{array}$ \\
\hline & Preg 4 & $\begin{array}{l}\text { Las ventajas competitivas que se pueden apreciar en las } \\
\text { empresas que han logrado intercambio comercial con } \\
\text { importadores franceses son los tiempos de respuesta } \\
\text { inmediatos, la calidad y tendencias de la prenda y la } \\
\text { capacidad productiva. Además se debería proponer } \\
\text { variedad de prendas innovadoras a un precio atractivo. }\end{array}$ & $\begin{array}{l}\text { La ventaja competitiva que tienen los exportadores } \\
\text { peruanos es que están catalogados como productores } \\
\text { de prendas de calidad. }\end{array}$ & $\begin{array}{l}\text { Conoce a la compañía peruana Aguaclara, se } \\
\text { encuentra feliz trabajando con ellos. Es una compañía } \\
\text { seria, de fácil comunicación trabajan por correo } \\
\text { electrónico gran parte del tiempo y en varios idiomas. } \\
\text { Aguaclara tiene precios correctos, la entrega es } \\
\text { perfecta y muy apreciable por los clientes y Sarl Bega. }\end{array}$ & $\begin{array}{c}\text { Las ventajas competitivas que se aprecian son la } \\
\text { capacidad de respuesta, tendencias, capacidad } \\
\text { productiva gracias a la calificación de Perú por ser un } \\
\text { país que produce prendas de calidad. Aguaclara es } \\
\text { una compañía seria, de fácil comunicación mediante } \\
\text { correo electrónico y en varios idiomas; asimismo } \\
\text { tienen precios correctos, la entrega es perfecta y es } \\
\text { apreciado por los clientes y Sarl Bega que se } \\
\text { encuentra feliz de trabajar con esta compañia } \\
\text { peruana. }\end{array}$ \\
\hline \multirow{2}{*}{$\begin{array}{c}\text { Categoria 2: } \\
\text { Barreras } \\
\text { arancelarias y } \\
\text { Proceso } \\
\text { Logistico }\end{array}$} & Preg 5 & $\begin{array}{l}\text { No existen barreras no arancelarias, tan sólo si en algún } \\
\text { momento el cliente solicita ciertas certificaciones, } \\
\text { además de cumplir con las reglas de etiquetado, } \\
\text { rotulado y documentos propios de la exportación. }\end{array}$ & $\begin{array}{l}\text { Barreras no arancelarias no existen, sólo deben } \\
\text { cumplir con los documentos de exportación de } \\
\text { acuerdo a las reglas de origen que corresponden a } \\
\text { cada destino. Para que el proceso de exportación sea } \\
\text { exitoso se necesita de apoyo financiero, tener claro el } \\
\text { fitting o plasmar lo que las prendas expresan en una } \\
\text { modelo y asistencia a ferias. }\end{array}$ & $\begin{array}{l}\text { No hay problemas de importación desde Perúa a } \\
\text { Francia ya que hay un impuesto libre en aduanas con } \\
\text { el Formulario A. El único problema es la tarifa de } \\
\text { transporte, en general es cara comparándola con } \\
\text { importaciones de Estados Unidos, el mismo problema } \\
\text { sucede con las importaciones de Colombia y Brasil. }\end{array}$ & \begin{tabular}{|l} 
No existen barreras no arancelarias ni trabas, sólo se \\
debe cumplir con las reglas de origen, etiquetado, \\
rotulado y ciertas certificaciones. Existe un impuesto \\
libre de Aduanas en las importaciones peruanas de \\
Francia. El único inconveniente que presentan son las \\
tarifas de transporte que son caras comparanándolas \\
con Estados Unidos, y lo mismo sucede con las \\
importaciones de Colombia y Brasil.
\end{tabular} \\
\hline & Preg 6 & $\begin{array}{l}\text { En el Perú el transporte, el proceso logístico y control de } \\
\text { tiempos es una de las falencias en el proceso de } \\
\text { exportación con respecto a otros países que en el menor } \\
\text { tiempo posible realizar traslados, cargas y descargas de } \\
\text { mercancias a precios competitivos. Se exporta mediante } \\
\text { la vía aérea por la rapidez, bajo costo en comparación de }\end{array}$ & $\begin{array}{l}\text { Los bikinis son prendas pequeñas y ligeras que no } \\
\text { ocupan mucho espacio y no estan costoso } \\
\text { transportarlas por vía aérea como síl os es por vía } \\
\text { marítima. El mercado al cual nos dirigimos es un } \\
\text { mercado exclusivo y no es masivo. }\end{array}$ & $\begin{array}{l}\text { Es como lo respondido en la anterior pregunta, el } \\
\text { transporte aéreo es alto debido a la menor frecuencia } \\
\text { de vuelos entre Perú - Francia que entre Miami - } \\
\text { Francia. Es la primera razón por la que cree que el } \\
\text { transporte aéreo es más alto que las importaciones } \\
\text { desde Estados Unidos, pero es casiel mismo precio } \\
\text { con Brasily Colombia. }\end{array}$ & $\begin{array}{c}\text { Para el exportador no es costoso realizar envios por } \\
\text { vía aérea como síl o es por vía marítima. Los bikinis } \\
\text { no ocupan mucho espacio ni peso ni volumen por lo } \\
\text { que se hace fácil su traslado. Para el importador es } \\
\text { costoso el transporte aéreo debido a la menor } \\
\text { frecuencia de vuelos Perú y Francia, lo mismo sucede }\end{array}$ \\
\hline
\end{tabular}




\begin{tabular}{|c|c|c|c|c|}
\hline & $\begin{array}{l}\text { la vía marítima, y por que la mercancía ocupa el menor } \\
\text { peso y volumen. }\end{array}$ & & & $\begin{array}{l}\text { con los envíos de colombia y Brasil; en cambio son } \\
\text { menos costosas las importaciones de Estados Unidos. }\end{array}$ \\
\hline Preg 7 & $\begin{array}{l}\text { El Tratado de Libre Comercio entre Perú y la UE trajó } \\
\text { consigo la rebaja arancelaria siguiendo las normas de } \\
\text { origen. }\end{array}$ & $\begin{array}{l}\text { Ayuda muchísimo para generar altos ingresos } \\
\text { comerciales. Se importan telas de países europeos } \\
\text { como Españâa, Francia e Italia para acogerse a los } \\
\text { beneficios arancelarios. El contenido es de } 15 \% \text { ó } 20 \\
\text { \% elastano y } 80 \% \text { a } 85 \% \text { poliamida. }\end{array}$ & No tiene información de ello. & \begin{tabular}{|c|} 
Ayudó mucho la vigencia del Tratado de Libre \\
Comercio entre Peru y la UE ya que brinda rebajas \\
arancelarias de acuerdo a las normas de origen. En \\
consecuencia, estas rebajas generan altos ingresos \\
comerciales para las compañias peruanas. Applauzi \\
importa telas de países europeos acogiéndose a los \\
beneficios arancelarios. Estas telas contienen $15 \%$ a \\
$20 \%$ elastano y 80 a $85 \%$ poliamida.
\end{tabular} \\
\hline Preg 8 & $\begin{array}{c}\text { Se necesita renovar, modernizar y ampliar las } \\
\text { instalaciones portuarias de manera que mejore la } \\
\text { afluencia y la competitividad del comercio exterior. } \\
\text { Crear la oferta de precios competitivos que incentive al } \\
\text { crecimiento de las operaciones de comercio exterior. Las } \\
\text { empresas privadas APM y DPWOLRD han contribuido a } \\
\text { mejorar la operatividad portuaria del país. }\end{array}$ & $\begin{array}{l}\text { Actualmente no se exporta por vía marítima, sólo en } \\
\text { alguna oportunidad cuando se exportó a Ecuador } \\
\text { pusieron barreras al ingreso de mercancía peruana. }\end{array}$ & $\begin{array}{l}\text { No tiene información sobre otras empresas peruanas, } \\
\text { sólo de Agua clara. Menciona que la entrega es } \\
\text { excelente, seria, correcta y tienen buena } \\
\text { comunicación comercial. }\end{array}$ & $\begin{array}{l}\text { Se necesita renovar y ampliar las instalaciones } \\
\text { portuarias y aéreas de manera que exista mayor } \\
\text { afluencia y oferta de precios competitivos } \\
\text { incentivando el crecimiento de las operaciones de } \\
\text { comercio exterior. Aguaclara cumple con las } \\
\text { entregas de manera excelente, correcta seria y } \\
\text { mantienen buena comunicación comercial. }\end{array}$ \\
\hline Preg 9 & $\begin{array}{l}\text { El exportador ayudará en el proceso de exportación si } \\
\text { tiene una empresa organizada en los procesos } \\
\text { operativos, administrativos y con la formalidad que el } \\
\text { caso requiere. Además de ello debe tener claro a donde } \\
\text { desea llegar y cómo lo realizará, es decir tener capacidad } \\
\text { de gestión empresarial para entablar negociaciones con } \\
\text { el mercado interno y externo a todo nivel. Las } \\
\text { instituciones públicas y privadas seguirán brindando } \\
\text { capacitaciones, asesorías, convenios y programas en los } \\
\text { cuales participen los empresarios y de esa manera apoye } \\
\text { a la internacionalizacion de las empresas. }\end{array}$ & $\begin{array}{l}\text { Hoy en día exportar es muy sencillo, si se exportan } \\
\text { cantidades grandes se necesita de un agente de } \\
\text { aduanas y ellos se encargan de todo, pero si son } \\
\text { despachos pequeños se realizan mediante Serpost. }\end{array}$ & $\begin{array}{c}\text { En Francia existe una institución, Chambre de } \\
\text { Commerce que puede ayudar a las marcas a } \\
\text { desarrollar clientes en Francia. Cada región tiene una } \\
\text { cámara de comercio, sólo lo ayudarán a darle atención } \\
\text { a los clientes. }\end{array}$ & \begin{tabular}{|c|} 
El exportador debe tener una empresa \\
completamente organizada en sus procesos \\
operativos y administrativos con la debida \\
formalidad. Las instituciones públicas seguirán \\
brindando capacitaciones, asesorías y la oportunidad \\
de particicipar en ferias, ruedas de negocio y \\
programas de internacionalización.Exportar es fácil si \\
son cantidades grandes lo realizan con el apoyo del \\
agente de aduanas y si son despacho pequeños \\
mediante Serpost. En Francia, la Cámara de Comercio \\
ayuda al desarrollo de clientes y a como brindar la \\
atención a los mismos.
\end{tabular} \\
\hline
\end{tabular}




\begin{tabular}{|c|c|c|c|c|c|}
\hline & Preg 10 & $\begin{array}{l}\text { El Gobierno tiene destinado una determinada cantidad } \\
\text { de dinero para promover actividades de comercio } \\
\text { exterior pero siempre se van a necesitar más recursos } \\
\text { para apoyar a más empresas. Mincetur busca optimizar } \\
\text { cada recurso analizando si fue útil de manera } \\
\text { cuantitativa la realización de ferias y ruedas de negocio } \\
\text { para el siguiente año mejorar esos indicadores. }\end{array}$ & $\begin{array}{l}\text { PromPeru y Mincetur realizan esfuerzos para e } \\
\text { impulso del comercio exterior, el presupuesto debiera } \\
\text { ser mayor para continuar apoyando a muchas } \\
\text { empresas a salir al mundo. Las constantes } \\
\text { capacitaciones, asesorías de diveros temas y } \\
\text { subsisdios de una parte del costo de la feria de } \\
\text { acuerdo a la evaluación de cada empresa crean } \\
\text { capacidad de gestión en los empresarios y negocien en } \\
\text { el mercado internacional. }\end{array}$ & $\begin{array}{l}\text { No tiene anécdotas sólo un buen recuerdo cuando } \\
\text { realizan las tarifas. }\end{array}$ & $\begin{array}{c}\text { El Gobierno peruano mediante Promperu y Mincetur } \\
\text { seguirán apoyando a la innternacionalización de las } \\
\text { empresas realizando un seguimiento constante de las } \\
\text { negociaciones. Además buscan optimizar cada } \\
\text { recurso que se empleen y de esa manera ayudar a } \\
\text { más empresas año tras año. }\end{array}$ \\
\hline \multirow[b]{2}{*}{$\begin{array}{l}\text { Categoria 3: } \\
\text { Comercio y } \\
\text { Demanda } \\
\text { Internacional }\end{array}$} & Preg 11 & $\begin{array}{l}\text { El crecimiento se debe a la capacidad de respuesta, al } \\
\text { conocimiento previo del mercado, alineación a gustos, } \\
\text { preferencias y tendencias. }\end{array}$ & $\begin{array}{l}\text { El crecimiento ha sido consecuencia del impulso de la } \\
\text { oferta en el mercado externo, al correcto timing y } \\
\text { fitting. Les gustaría participar en mas exhibiciones y } \\
\text { ferias especializadas de bañadores porque tienen } \\
\text { prendas de calidad y con la ultima tendencia exclusiva } \\
\text { para el exigente mercado internacional. }\end{array}$ & $\begin{array}{c}\text { No sabe si ayudó a la importación pero desde hace } 10 \\
\text { años ha visto el desarrollo de marcas colombianas y } \\
\text { brasileñas. La única marca peruana que ha visto es } \\
\text { Aguaclara. }\end{array}$ & $\begin{array}{l}\text { El sectorde bañadores creció debido a la capacidad de } \\
\text { respuesta, conocimiento del mercado, tendencias y } \\
\text { preferencias. Aplicando el correcto timing, fitting, } \\
\text { participando ferias especializadas brindando al } \\
\text { mercado prendas exclusivas y con las últimas } \\
\text { tendencias. Desde hace } 10 \text { años se han desarrollado } \\
\text { muchas marcas colombianas y brasileñas en Francia, } \\
\text { pero la marca peruanas que se ha visto es Aguaclara. }\end{array}$ \\
\hline & Preg 12 & $\begin{array}{l}\text { La ferias son relevantes y es una buena oportunidad } \\
\text { para los planes de internacionalización de una empresa. } \\
\text { Mincetur ha lanzado un programa de apoyo a la } \\
\text { internacionalización para que participen las empresas } \\
\text { con objetivos claros de inversión en el extranjero. } \\
\text { Programa con un fondo de } 25 \text { millones de soles para ser } \\
\text { invertidos en proyectos concretos de comercio exterior. } \\
\text { Las capacitaciones brindan apoyo, soporte, herramientas } \\
\text {,capacidad de gestión y de ventas para el } \\
\text { desenvolvimiento empresarial. }\end{array}$ & $\begin{array}{c}\text { Es muy importante el desarrollo de múltiples ruedas } \\
\text { de negocios y ferias internacionales sobre todo que } \\
\text { sean especializadas de bañadores como las de Miami, } \\
\text { Francia y New York. Applauzi ha particpado } \\
\text { exitosamente en el PAl debido excelentes indicadores } \\
\text { ecónomicos de sus estados financieros y proyecto de } \\
\text { inversión de franquicias en México. Ya firmaron } \\
\text { contrato con Mincetur y están próximos a iniciar las } \\
\text { reuniones sobre las operaciones documentarias para } \\
\text { ello. Participaron un total de } 200 \text { empresas pero } \\
\text { ganaron } 7 \text { empresas ya que cumplín con la } \\
\text { formalidad y correcto análisis del proyecto que el } \\
\text { caso requiere. }\end{array}$ & $\begin{array}{l}\text { Hasta el momento no ha sido invitado por Mincetur. } \\
\text { Sólo ha sido invitado por una institución colombiana en } \\
\text { Medellin y por Apex el año pasado. }\end{array}$ & $\begin{array}{l}\text { Con la asistencia a continuas ferias especializadas y } \\
\text { participación en programas de internacionalización } \\
\text { las compañias de trajes de baño tendrán el desarrollo } \\
\text { exitoso y sostenible deseado. El importador Sarl Bega } \\
\text { hasta el momento no ha sido invitado por Mincetur a } \\
\text { alguna feria, pero a sido partícipe de una invitación de } \\
\text { una institución colombiana en Medellín y Apex el año } \\
\text { pasado. }\end{array}$ \\
\hline
\end{tabular}




\begin{tabular}{|c|c|c|c|c|}
\hline Preg 13 & $\begin{array}{l}\text { El PAl tuvó una primera selección de ganadores que } \\
\text { comprende a } 7 \text { empresas que destacaron por su nivel de } \\
\text { ventas, capacidad productiva e indicadores económicos. } \\
\text { Una de las empresas ganadoras es Applauzi; dicha } \\
\text { empresa diseño un Proyecto de Franquicias en México } \\
\text { con la marca Agua Clara. }\end{array}$ & $\begin{array}{l}\text { Continuar con la esmerada labor de contactar con } \\
\text { clientes potenciales en ruedas de negocios, ferias y } \\
\text { misiones internacionales. Las principales empresas } \\
\text { exportadoras peuanas son Applauzi, Toque D'sol, } \\
\text { Capittana, Besos de Sal, Sabz, etc. }\end{array}$ & $\begin{array}{l}\text { Sólo trabaja con Aguaclara y está dispuesto a trabajar } \\
\text { con otras compañias que lo ayuden a importar sus } \\
\text { productos. Además puede abrir su sitio web } \\
\text { bestofbikinis.fr para otras marcas que quieran vender } \\
\text { en Francia y Europa. Además hace cortos para } \\
\text { caballeros en su sitio web shortavenue.fr }\end{array}$ & $\begin{array}{l}\text { El PAl continuará beneficiando a muchas empresas en } \\
\text { la medida que su desarrollo sea sostenible y sus } \\
\text { proyectos sean beneficiosos para el desarrollo del } \\
\text { comercio exterior. Los exportadores continuarán con } \\
\text { su labor de contactar cada vez a más clientes } \\
\text { potenciales en ferias y en todo evento especializado } \\
\text { se presente. El importador Sarl Bega está dispuesto a } \\
\text { trabajar con otras compañias tan organizadas como } \\
\text { Aguaclara que le permita continuar brindando alos } \\
\text { clientes un producto de calidad, exclusivo y con la } \\
\text { última tendencia de la moda para damas y caballeros. } \\
\text { Compañias que deseen vender no sólo en Francia sino } \\
\text { en toda Europa. }\end{array}$ \\
\hline Preg 14 & $\begin{array}{l}\text { Las empresas que destacan son Applauzi, Toque D'sol, } \\
\text { Capittana. }\end{array}$ & & & \\
\hline Preg 15 & $\begin{array}{l}\text { Las actividades que deberían realizar son: crear sinergias } \\
\text { de las cadenas productivas, trabajando de la mano } \\
\text { exportadores, asesores de diversas instituciones } \\
\text { públicas, gremios del rubro, proveedores, etc. Realizar el } \\
\text { seguimiento de las reuniones de negocios } \\
\text { internacionales hasta que se concrete tal comosi fuése } \\
\text { un matrimonio aprovechando las oportunidades de } \\
\text { negocio que en el mercado se presentan. }\end{array}$ & & & \\
\hline
\end{tabular}

